\title{
FROM GARAGE INVENTOR TO GARAGE ENTREPRENEUR
}

\author{
Kevin Anthony Miceli
}

A dissertation submitted to the faculty of the University of North Carolina at Chapel Hill in partial fulfillment of the requirements of the degree of Doctor of Philosophy in Business Administration from the Kenan-Flagler Business School in the Strategy and Entrepreneurship area.

Chapel Hill

2016

Approved By:

Atul Nerkar

Scott Rockart

Richard Bettis

Christopher Bingham

Howard Aldrich 
(C) 2016

Kevin Anthony Miceli

ALL RIGHTS RESERVED 


\begin{abstract}
Kevin Anthony Miceli: From Garage Inventor to Garage Entrepreneur (Under the direction of Atul Nerkar)
\end{abstract}

The American garage serves as the backdrop for the image of the independent entrepreneur. However, literature highlights the importance of resources for entrepreneurs that are derived from experience in firms, universities, or markets. This dissertation investigates how theories from those entrepreneurship studies can be applied in the context of independent ("garage") invention that results in garage entrepreneurship. In studying the process used by garage entrepreneurs, it elucidates how the technological, social, and geographical opportunity spaces present in the pre-venture period could affect the decision to form a new venture.

Using data of non-affiliated technologies from the USPTO during 1975-2009, I analyze inventors and technologies that are at risk of forming a firm in order to understand which characteristics increase the likelihood of entrepreneurship given prior technological development. In the data, I identify a risk-set of 152,092 inventors who will start 5,684 new firms. I find that the nature of the opportunity spaces through competition and resources is associated with the transition from inventor to entrepreneur and increased experience and network strength can substitute for organizational affiliation. Finally, while all inventors in this study start independently in the metaphorical garage, those who transition to an existing company are more likely to spin back out after experience in smaller firms and twice as likely to start a new firm as those who do not join an existing organization. 
Keywords: independent inventors; technological entrepreneurship; opportunity spaces; technological evolution; entrepreneurial spin-outs 


\section{Dedicated to my family:}

My wife, Caroline,

\section{And my children, Logan and Connor}




\section{ACKNOWLEDGEMENTS}

Someone once told me that you should write with the end in mind. This section is the last part of my dissertation to be written and I have frequently said that I looked forward to writing such acknowledgments. That excitement and longing was true not only because it meant that I will have written a dissertation at the point, but because I have longed to express my immense gratitude and love for the people who have made this possible. Even before it was done, I have long wanted to recognize their support.

I want to thank my family. In particular, my incredible spouse and partner, Caroline. "Acknowledgments" and "thanks" cannot even begin to express my feelings towards Caroline as I conclude the $\mathrm{PhD}$. She has supported me whole-heartedly through all of this. It is going on seven years since I told her that I wanted to quit my job, move, and go back to school for a full-time MBA program. And as soon as I got back into school, I thought about staying to earn a $\mathrm{PhD}$. This was not intended to be a two-year/five-year bait-and-switch, even though she will joke about that sometimes. After all this time, I still do not know what to say to her. We have journeyed together through time and space and I believe it has been incredible. Caroline has supported me, kept our lives organized so I could do what I needed, and has been raising our two loving children. She has made everything in our life possible. Certainly this dissertation would not be what it is without her.

Next, my children, Logan and Connor. They kept me honest as I managed my time. I needed to be home at 5:30 so I could have dinner and do bath time and read for bedtime with them. That time was important. That time was precious. I had to be efficient at work. 
The evenings were mostly protected for this reason. They also knew this was temporary and encouraged me with the things we will do "when daddy graduates," while still offering me smiles, laughter, requests for train time, and enjoyment of our life right now.

While Logan was technically born before I went back to school while I was still working at GE, essentially his entire life so far has been lived with me in school. This journey has been more meaningful to me because he has been with us. Logan has journeyed through all the different cities, states, countries, schools, houses, and apartments. Connor was a gift during the doctoral program. The benefits of academic life were reinforced as I could stay home with him when needed or he could come with me. Connor has come to school with me when necessary, enjoying blue lollipops and the occasional iPad time, and played dinosaurs and trains when we met Atul at his house. He has dissertated with me much more than he realizes.

Besides my family, I would like to acknowledge the incredible support of my advisor, Atul Nerkar. Once again, the word "acknowledge" seems too cold for what Atul has given me. He has challenged me to really become a scholar and pushed me to do more and think harder about our problems. He loves this career. He loves the academic freedom. He loves the questions we can ask and the possibility of data that can answer those questions. The excitement he has for our research is incredible. Atul has certainly given me so much over the course of the program: academic and moral support, his time, good coffee, and the occasional ride to and from school, to say the least. And at the end of the day, Atul has called me a colleague. I thank him for all of that and more. He has always pointed out that the dissertation represents only the start of an academic career. And I can only hope to live up to his expectations going forward. 
There have been so many other people during program. My teachers: Atul, Rich Bettis, Nandini Lahiri, Scott Rockart, Chris Bingham, Howard Aldrich, Jeff Edwards, Rich Burton, Ashish Arora, and Wes Cohen. Rich, Howard, Chris, and Scott all served on my dissertation committee and I thank them for their perspectives. Rich brought me into this program, serving as advisor in the first year, and offering many conversations on academia over the years. His mentoring and constant presence has been a gift. Scott is a consummate academic who has provided me countless hours both as an advisor and co-author. I am grateful for his time, knowledge, and the opportunity to work with and learn from him.

I would be remiss without thanking all my friends and colleagues in the program that I spent so much time and conversation with - both productively and unproductively particularly $\mathrm{CH}$ Kim and Tian Chen. This is what I will really remember about my time in on the fifth floor of McColl. I would also like to thank Amol Joshi, Songcui Hu, Susan Cohen, Jim Berry, Virginia Stewart, Deirdre Snyder, Karthik Natarajan, Erin Cooke, Tali Kapadia, Aleks Rebeka, Rajat Khanna, Alex Wilson, and Colleen Cunningham. Each offered friendship and a unique perspective that has helped me during the program.

Finally, I would like to thank my parents, Susan and AJ Miceli. They instilled a love of education and the pursuit of knowledge. They have inspired me throughout my years. And while my father, who is a professor and a tech entrepreneur, would not qualify under my strict definition of garage inventor and garage entrepreneur for this dissertation, he has been a personal model for me throughout my life and I have thought about his professional experiences and career a lot as I developed the following work. The "garage" in this dissertation is a metaphor and his businesses in fact started in my grandparents' converted cottage and the basement of the Buseck, Barger, Bleil, and Co. accounting building even. I 
remember my mother going back to school to complete her Master's degree when I was a child. Together, they set me on this path and provided examples of academics before I even knew what I was learning from them. Similarly, I would like to thank my in-laws, Mary Ann and Robert Granahan. They have provided significant support to me and my family through this process which has helped to make this possible and it is greatly appreciated.

To all the other faculty and staff at UNC, I thank you. Additionally, this work has benefitted from the comments of many of these individuals, as well participants at AOM and SMS conferences, CCC Boston, and my job-talks. I thank all those scholars.

For everyone I have missed, I thank you and look forward to saying so in person! 


\section{PREFACE}

What if everyone could have one of these amazing machines in their own house? There's just one problem: They're as big as a house. The solution comes in, of all places, a garage in California. Young people with a passion for shaping the future put the power of the computer in everyone's hands. Together, we form a super network that glows with billions of interactions, and once again we stand on the brink of a new Renaissance.

... For the first time in history, all of us can have a say about the kind of world we want to live in. The choices we have made for the past 30,000 years have been inventing the future one day at a time. And now, it's your turn.

\section{Spaceship Earth, EPCOT}

A Garage and an Idea: What More Does an Entrepreneur Need?

Audia and Rider (2005)

Okay, well... probably a lot. 


\section{TABLE OF CONTENTS}

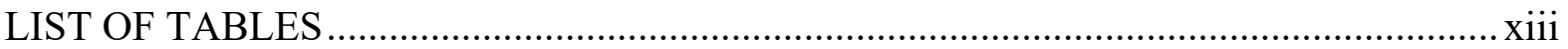

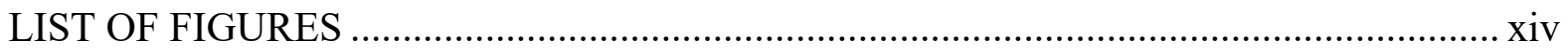

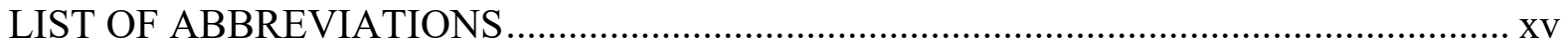

CHAPTER 1: INTRODUCTION ............................................................................. 1

CHAPTER 2: RESEARCH PHENOMENON ........................................................ 4

Classic Debates............................................................................................ 4

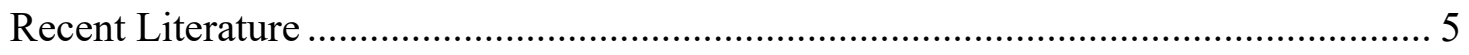

Garage Inventor to Garage Entrepreneur ........................................................... 10

CHAPTER 3: THEORY AND HYPOTHESIS DEVELOPMENT .................................. 13

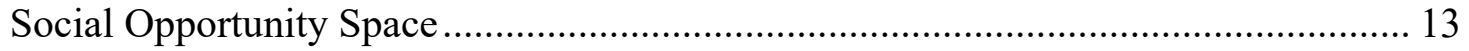

Technological Opportunity Space ................................................................... 15

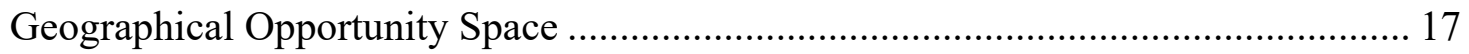

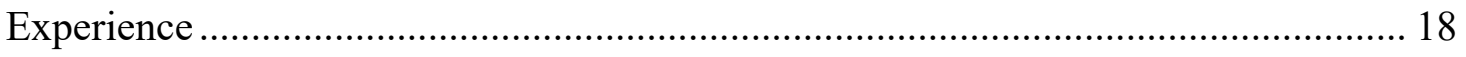

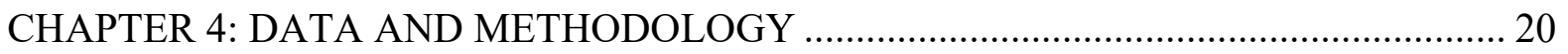

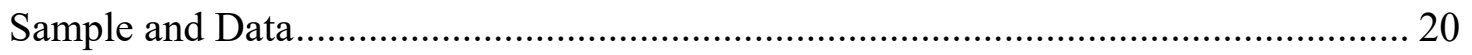

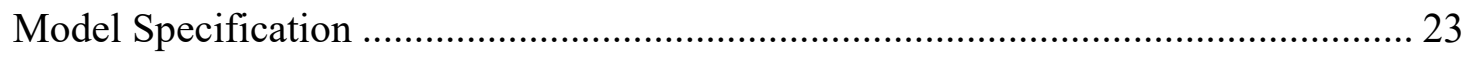

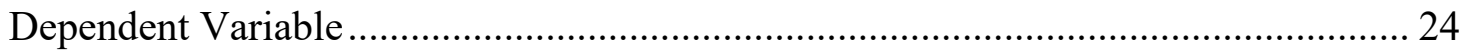

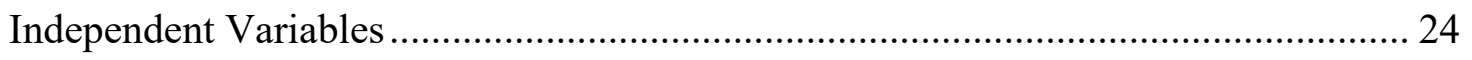

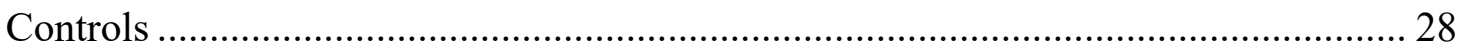

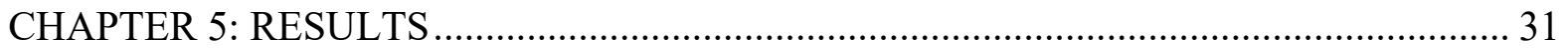




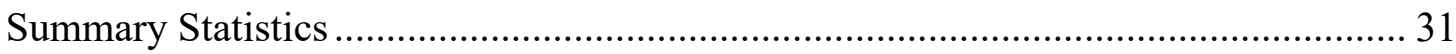

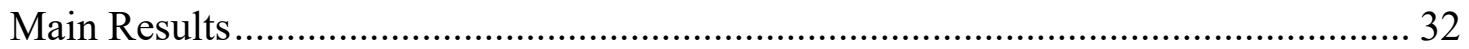

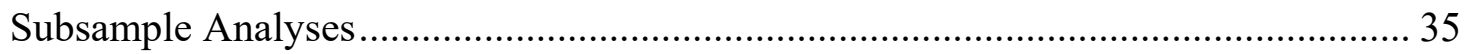

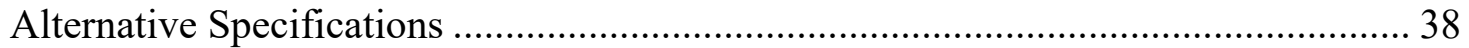

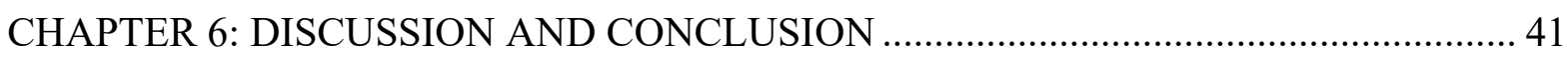

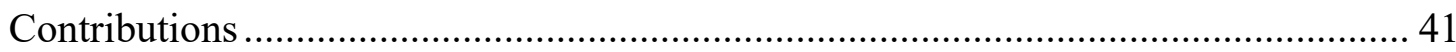

Limitations and Future Directions for Research .................................................... 43

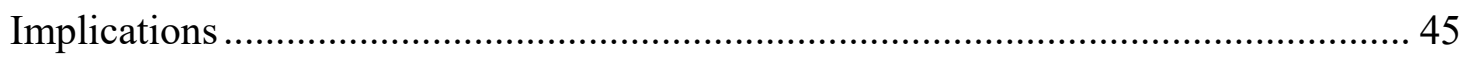

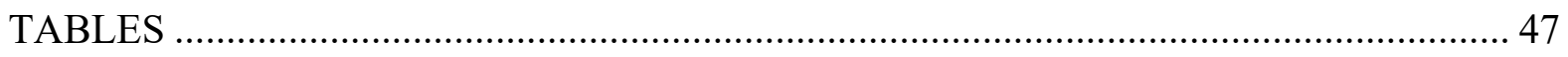

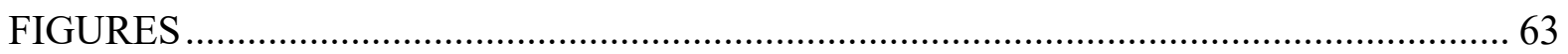

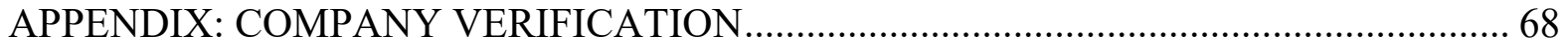

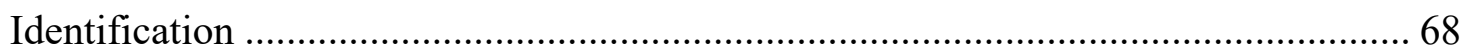

Example Search Process and Vignettes........................................................................ 71

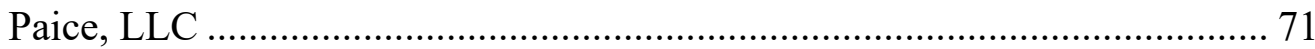

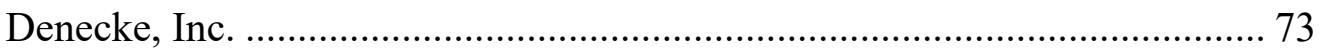

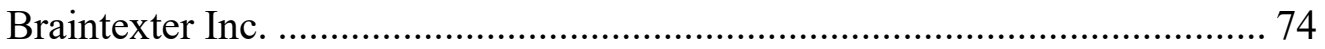

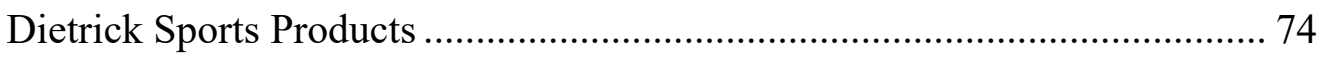

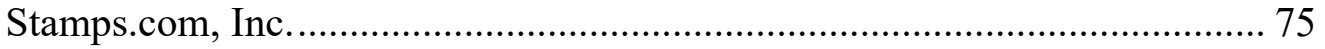

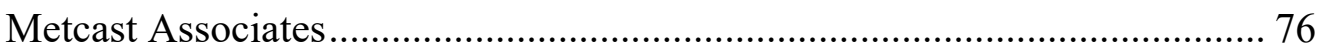

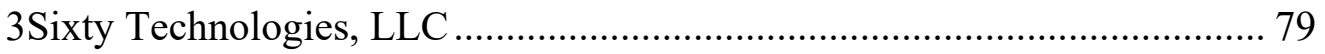

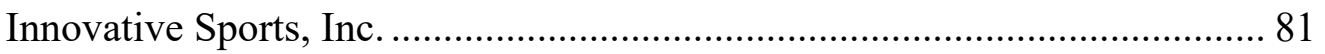

Example Technologies Never Associated with New Firms ........................................ 83

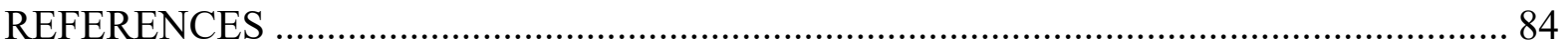




\section{LIST OF TABLES}

Table 1: Initial Statistics from Patent Data ................................................................ 47

Table 2: Descriptive Statistics .............................................................................. 48

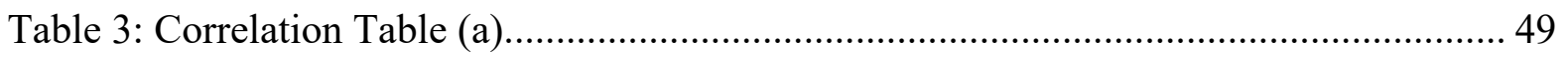

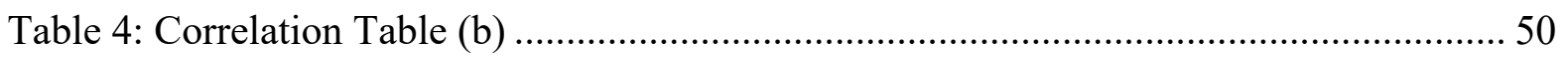

Table 5: Descriptive Statistics by Entrepreneurship Condition........................................ 51

Table 6: Garage Invention and Entrepreneurship Statistics by State............................... 52

Table 7: Results (a) - Cox Proportional Hazard Models ................................................. 54

Table 8: Results (b) - Cox Proportional Hazard Models.................................................. 56

Table 9: Results (c) - Cox Proportional Hazard Models ................................................. 58

Table 10: Interaction Model with Post-Firm Affiliation (Cox Model)................................ 60

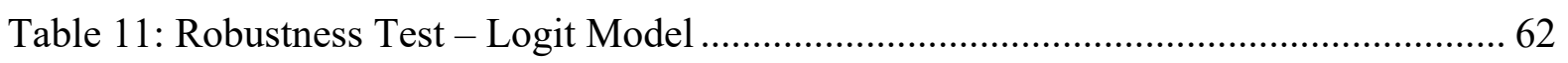

Table 12: Firm Founding Verification Table by Year .................................................. 70

Table 13: Summary of Firm Founding Verification ................................................ 71

Table 14: Example Technologies and Inventors Never Associated with a New Firm .......... 83 


\section{LIST OF FIGURES}

Figure 1: Basic Model of Garage Entrepreneurship ........................................................ 63

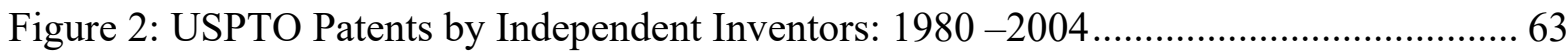

Figure 3: Firm Foundation Delay from Last Patent for Garage Inventors .......................... 64

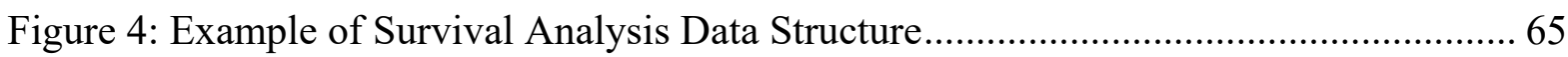

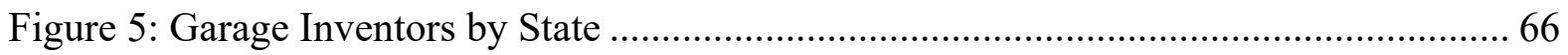

Figure 6: Garage Inventors Weighted by State Population (per million) ........................... 66

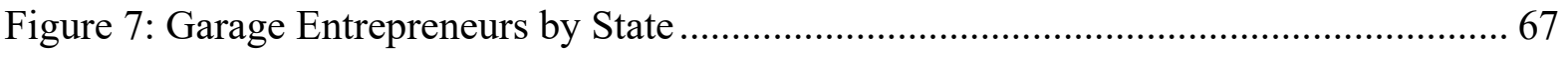

Figure 8: Garage Entrepreneurs Weighted by State Population (per million)...................... 67

Figure 9: Donald Cech's Invention of "Releasable Axle Assembly for Skate Wheels" ....... 75

Figure 10: Mohan Ananda LinkedIn Profile - Stamps.com................................................ 76

Figure 11: Daniel Groteke Garage Patent.................................................................... 77

Figure 12: Daniel Groteke Entrepreneur Patent......................................................... 77

Figure 13: Example Search Result Showing Metcast Associates Founding Date................ 78

Figure 14: Example Founding Information for 3sixty Technologies, LLC....................... 80

Figure 15: Brent Jones Garage Patent 5,678,344................................................ 81

Figure 16: Innovative Sports Garage Entrepreneurial Patent 6,119,388 ......................... 81

Figure 17: News Search Results Detailing Innovative Sports' Founding year ................... 82 


\section{LIST OF ABBREVIATIONS}

$\begin{array}{ll}\text { HHI } & \text { Herfindahl-Hirschman Index } \\ \text { hr } & \text { Hazard Ratio } \\ \text { IAP } & \text { Inventor's Assistance Program } \\ \text { IRR } & \text { Internal Rate of Return } \\ \text { MSA } & \text { Metropolitan Statistical Area } \\ \text { NBER } & \text { National Bureau of Economic Research } \\ \text { or } & \text { Odds Ratio } \\ \text { se } & \text { Standard Error } \\ \text { SMS } & \text { Simple Messaging Service } \\ \text { UIA } & \text { United Inventors Association } \\ \text { USPTO } & \text { United States Patent and Trademark Office } \\ \text { VSR } & \text { Variation-Selection-Retention }\end{array}$




\section{CHAPTER 1: INTRODUCTION}

Where do new organizations come from and who is at risk of founding those organizations? These are two of the fundamental questions in organizational and entrepreneurship research (Aldrich and Ruef, 2006; Gartner, 1985; Krueger, 2002; Shane and Venkataraman, 2000). An enduring image in American culture is the heroic "garage inventor" turned entrepreneur (Audia and Rider, 2005; Cohen, 2011; Engber, 2013). This study, starting with the metaphorical garage, clearly identifies a set of individuals at risk of starting a firm in order to isolate and address the first question in the technological space, a phenomenon addressed as the "garage entrepreneur" for this study.

The garage has served as the setting for new entrepreneurs like such as Roy and Walt Disney leading to the Walt Disney Company, Ruth Handler who created the Barbie Doll and founded Mattel, Steve Jobs and Steve Wozniak of Apple, and Bill Hewlett and David Packard for Hewlett-Packard (Cohen, 2011). Hewlett and Packard's story was so important that the garage they worked in is a designated historic landmark as the birthplace of Silicon Valley (Engber, 2013).

This dissertation studies the transition from independent invention to the start of new technological firms. In doing so, it investigates one of the first selection mechanisms along the evolutionary path from technological discovery to commercialization and market acceptance. Investigating the role of independent inventors in new firm formation, the research question is: what factors at the potential founding time affect the likelihood of a garage inventor becoming a garage entrepreneur? 
In addressing the phenomenon, I will be investigating problems at the intersection of strategy, technology, and entrepreneurship. With respect to innovation, Teece (1986) highlights the difference between value creation and value capturing in technological innovation. Having overcome the challenge of creating a new technology, these inventors still face great obstacles in identifying means of protecting and profiting from their ideas (Gans, Hsu, and Stern, 2002). Prior research in technological venture formation frequently focus on knowledge sources for entrepreneurship that include firm spin-offs and employee entrepreneurship (Chatterji, 2009; Klepper, 2007; Klepper and Sleeper, 2005), university transfer (Katila and Shane, 2005; Shane, 2001a; Stuart and Ding, 2006), and user entrepreneurship (Shah and Tripsas, 2007; Tripsas, 2008). In each setting, the entrepreneur is able to overcome the complementary asset problem using different resources from his or her experience.

I am interested specifically in the perspective of the non-affiliated inventor(s) and the technology and context around them. Rather than from the perspective of the incumbent fearing disruption (Christensen, 1997), I explore the garage inventors and how the technological, social, and geographical environmental characteristics affect entrepreneurship. In doing so, I connect with recent research efforts that encourage investigation into the entrepreneurship processes not affiliated with firms or universities (Åstebro, 1998; e.g. independent inventors - Åstebro and Dahlin, 2005; 'Edisons or Hobbyists' - Dahlin, Taylor, and Fichman, 2004; 'user entrepreneurs' - Shah and Tripsas, 2007).

Utilizing a process model of entrepreneurship (Shane and Venkataraman, 2000), this study takes place after potentially recognizing an opportunity but before success or failure of commercialization. This space evaluates the inventor's decision to form a venture but not 
necessarily whether it is yet successful. In doing so, I am able to highlight a step in an evolutionary process for which inventors select themselves (or are selected) into entrepreneurship. This selection mechanism allows an insight into the options that are presented for later market selection.

In order to answer the question, I consider theories developed in other settings that resulted in entrepreneurial startups such as through university and firm spin-offs. While I draw from the logic that proved valuable in those settings, it is not immediately known if all the theories will hold in the same manner, and complement the theories with inventor independence. Independent inventors do not have access to the same resources or networks and may not develop technologies in line with those sources. I specifically develop hypotheses surrounding the nature of the technological, social, and geographical opportunity spaces in which the nascent entrepreneurs are operating. 


\section{CHAPTER 2: RESEARCH PHENOMENON}

"Face it: Out there in some garage, an entrepreneur is forging a bullet with your company's name on it." - Gary Hamel (1999: 72)

The role of independent inventors and/or small firms have been debated in the literature (e.g. Amesse et al., 1991; Cohen, 2010; Fontana et al., 2012) for some time.

\section{Classic Debates}

Joseph Schumpeter is frequently seen as arguing on both sides and starting the debate of the importance of entrepreneurs and technological development, which is the engine of economic growth in his models. Schumpeter's gales of creative destruction are either primarily the realm of innovative entrepreneurs developing new technologies through radical new combinations of existing ideas and destabilizing the incumbents (Schumpeter, 1934) or are the product of the large R\&D laboratories (Schumpeter, 1942) where large firms play a very important role. In economics, this argument has frequently been evaluated as determining the firm size (Cohen and Klepper, 1996b; Prusa and Schmitz Jr., 1991) or market structure that promotes innovation - i.e. do large monopolists have the incentive to innovate to avoid future competition (Cohen and Levin, 1989; Scherer and Ross, 1990)?

In the mid-twentieth century, scholars pick up the debate between inventors and large R\&D labs again. In 1957, Jacob Schmookler addressed the prevailing idea that the inventor no longer has a place in innovation. He concluded that the large-scale enterprises are unquestionably contributing to technological progress but claiming that large $\mathrm{R} \& \mathrm{D}$ firms alone drive advancement is "entirely unwarranted" (Schmookler, 1957: 330). In his sample, 
$14 \%$ percent of the inventors assigned their patent to themselves or unassigned rather than a firm or the government. Additionally, he found that $7 \%$ of the inventions by technologists were "Not Part of [the] Job" (Schmookler, 1957: 332).

Jewkes, Sawer, and Stillerman (1971) similarly studied great inventions of the early twentieth century. In a study of sixty major inventions, half of them were invented by individual inventors without the support of research institutions. They evaluate that studies "continue to provide evidence of the important role of the independent inventor" (Jewkes et al., 1971: 205). They do however include university researchers in the independent category as long as the invention could clearly be linked to the efforts of the specific inventor and as long as the inventors were working autonomously, even within the university context. In more recent years, university spin-offs, that could have been some of those represented as independent in their sample, have received attention in academic literature (Foray and Lissoni, 2010; Jaffe, Fogarty, and Banks, 1998; Katila and Shane, 2005; Nerkar and Shane, 2003; Shane, 2001a). At the time of the Jewkes, Sawer, and Stillerman study, the rate of patenting amongst independent inventors had been declining. They acknowledge that the type of invention going forward may yet make laboratories and firms the source of invention, but conclude that it is still important to keep researching all avenues of such invention.

\section{Recent Literature}

More recently, Audia and Rider (2005) performed a study specifically on the image of the "garage entrepreneur." They conducted a random phone survey to test the popularity of the myth, finding that $87 \%$ of respondents could name at least one company started in a garage, basement, dorm room, or kitchen - where Apple and HP were the most likely responses. In a survey of 32 startups with VC funding in 2004, they found that $25 \%$ of the 
firms did start in garages, basements, dorm rooms, or kitchens. However, these were temporary locations early on and the authors highlighted that $91 \%$ of the companies were related to the founders' prior industry experience and prior social ties were important in $66 \%$ of the companies. They state that entrepreneurs are organizational products and feel that the image can be detrimental to individuals trying to become entrepreneurs by not emphasizing the social and knowledge source aspects and policy makers, business schools, and popular press should not highlight the phrase. Audia and Rider conclude that research on individual entrepreneurship should focus on identifying access to organizations, which can provide information on opportunities, role experience, social contacts, and access to key resources.

Other recent scholars have been calling for more studies in relation to independent inventors and innovation (e.g. Åstebro, 1998; Dahlin et al., 2004; Shah and Tripsas, 2007). Åstebro performed a survey of Canadian inventors who sought help from the Inventor's Assistance Program (IAP). With 1,095 responses, he was therefore able to study a sample of inventors with information at the time of IAP application as well as measures of performance from his independent survey. He reported the results in a series of articles.

Åstebro found that $6.5 \%$ of inventions by independent inventors reach the market, four-to-eight times less than inventions by established firms (Åstebro, 1998). However, he found that, conditional on commercialization, costs of development were about $1 / 8$ those of other firms and they were able to obtain gross margins comparable to established firms. Specifically, of the 75 firms in his sample that reached commercialization, the average IRR was $11.4 \%$. The returns were highly skewed though as six realized returns above $1400 \%$ and $60 \%$ obtained negative returns (Åstebro, 2003). He also noted that while $75 \%$ of the 
inventors were told by the IAP not to pursue their idea commercially, $50 \%$ of those continued working on it (Åstebro and Gerchak, 2001).

Evaluating the characteristics of success in his sample, Åstebro reported that of 36 characteristics of innovation, technology, and the market, four stand out as being related to eventual success: expected profitability, technological opportunity, development risk, and appropriability conditions (Åstebro, 2004). Clarifying further, technological opportunity is related to commercialization if the inventor believed his or her invention had high technical performance and low technical uncertainty (Åstebro and Dahlin, 2005). They suggest that the independent inventors applied for patents without taking into account commercialization considerations based on their survey results. Lastly, Åstebro and Dahlin find that the dominant mode $(82 \%)$ of sales is through self-commercialization with the inventor involved. Regarding profitability expectations, the significant characteristics were price required for profitability and anticipated stable demand (Åstebro and Michela, 2005).

In a different study, Dahlin, Taylor, and Fichman (2004) took up the debate whether independent inventors were "future Edisons or weekend hobbyists." They sought to answer whether there was significant technical content and merit to encourage policy support of independent inventors. In the specific setting of tennis racket patents, they found that $65 \%$ of patents were held by independent inventors as compared to corporates and $59 \%$ of the independent inventors held multiple patents in the area. Analyzing the nature of independent inventions as compared to those developed by firms, the authors found that there is significant variation in the quality of inventions by independent inventors. They found that independent inventors are over-represented in both the most important and the least important pool of inventions in this category. 
Singh and Fleming (2010) address the debate on the importance of variance in independent inventor outcomes as well, coming to different conclusions. Following literature that suggests variance is the important measure for creative outcomes (Fleming, 2001, 2007; Girotra, Terwiesch, and Ulrich, 2010), Singh and Fleming seek to test whether variance and mean performance are positively related in a large sample of patented inventions. Rather than suggesting that merely having variance is a good thing, they suggest that independent inventors will be more highly represented in the lower tail and less highly represented in the upper tail as compared to corporate inventors. They argue that corporate and team-based inventions will be better selected so as to eliminate poor outcomes prior to patenting. Additionally, corporate and team invention carry benefits such as access to a greater variety of knowledge to recombine - thus increasing the likelihood of creating breakthrough ideas. They supported this argument using quantile regression on over half a million patents that independent inventors are more likely to produce very poor outcomes and simultaneously less likely to create breakthroughs as compared to their corporate partners. They do not address entrepreneurship or commercialization but aim to enhance the debate on the (non-)importance of independent inventors based on their comparative inventive output.

In another study, Sirilli (1987) completed a study on over 500 inventors who filed patents under the Italian patent system in 1981 . He found that $60 \%$ of the respondents were associated with a firm and the other $40 \%$ were "individual" inventors, although the population of patents from which his sample was drawn showed $51 \%$ of the patents had firm association in 1981 according to the Patent Office. Sirilli's main emphasis was on describing the background of the inventors in the sample and the incentives for invention. He found that 
nearly three-quarters of the inventors claimed their invention would have been developed even in the absence of the patenting institution. However, he still found patenting important and necessary for protecting their inventions.

Weick and Eakin (2005) repeat the call for more studies of independent inventors. In a short survey, they sought to investigate who these inventors are, measure the level and direction of their inventive activity, analyze how frequently these inventors take their products to market and in what manner, and test the correlations between sales achieved and market choices such as outright invention sale, start-ups, or licensing. Surveying individuals on the mailing list of the United Inventors Association (UIA) and the Inventors' Digest, they received 351 responses to a questionnaire on biographical and invention details, which represented a $9 \%$ response rate as measured over the total size of the mailing list. Most of their responses tended to work on hardware/tool, household products, industrial/commercial products, novelty items, and toys/games/hobbies. They found that $39 \%$ of their population generated some sales and $20 \%$ made a profit. In this sample, higher likelihood of achieving any sales was associated with starting their own business but a higher level of sales was associated with licensing rather than outright invention sale or starting their own business.

Lastly, a rising area of interest in the literature is highlighting user entrepreneurship (Chatterji and Fabrizio, 2014; von Hippel, 1988; Shah, Smith, and Reedy, 2012; Shah and Tripsas, 2007). From Shah and Tripsas (2007), the definition of user entrepreneurship is "the commercialization of a new product and/or service by an individual or group of individuals who are also users of that product and/or service" (Shah and Tripsas, 2007: 124). They further segment this into two categories: professional-users and end-users. In this definition, it is not strictly restricted to individuals outside of work or research relationships. The area 
significantly overlaps, especially with end-users or consumer goods and sports products, which has been tested under the user entrepreneurship model (Fauchart and Gruber, 2011; Shah, 2005). However it also includes physicians using medical devices and providing their feedback to the manufacturers (Chatterji and Fabrizio, 2012). Shah and Tripsas (2007: 123124) specifically call for increasing the study of entrepreneurship out of the regular contexts of firm and university spin-offs which leads them to the area of demand-use and user entrepreneurship. I repeat the call for study outside of university, firms, or other organizations but suggest that the alternative category is broadly independent invention. I then do not yet assume characteristics of the motivations of the inventors and entrepreneurs but define the scope of this study based on their working relationship, primarily through a clear patenting relationship with an existing organization prior to the inventor become independent.

To wrap up the question of significance, a recent study on the acquisition and commercialization of invention suggests that $49 \%$ of manufacturing firms that innovated during $2007-2009$ did so with a product that originated outside the focal institution, namely through customers, suppliers, and "technology specialists" that included independent inventors (Arora, Cohen, and Walsh, 2014). They found that while customers were the most frequent source of such inventions, technology specialists provided inventions that were more economically valuable.

\section{Garage Inventor to Garage Entrepreneur}

For this study, I use two terms that define the context and constructs - a garage inventor and a garage entrepreneur. A "garage inventor" is an individual or individuals whose technological product or process, embodied in their first patent, is developed 
outside the context of a firm, university, government, or other formal organization. Specifically, the inventors own the technologies themselves rather than assigning it to another organizational entity. It is important to note that this definition does not include all independent inventors where a technology is not assigned to an organization. The "garage" status of an inventor is defined at the time of his or her first patent. Inventors who first develop technologies for an existing firm may later have independent (i.e. non-assigned) patents but they will not be considered "garage" under this definition. Additionally, this status is limited to independence of an organizational affiliation but not limited by "lone wolf' inventive status where the inventor does not work with anyone in the invention stages. In fact, the co-inventing relationships will prove to be important substitutes for working relationships. A "garage entrepreneur" is the garage inventor who subsequently starts a new technological firm after such invention. A garage entrepreneur will therefore be a subset of garage inventors for this context. This differentiates from inventor/entrepreneurs associated with other new technological entities in the patent database. To test knowledge use and development for garage entrepreneurship, I focus solely on the venture formation conditional on having developed a new technology. This results in the study highlighting this type of technological entrepreneurship where technologies were not spun out from previous entities. See Figure 1 for an evolutionary model of the Garage Entrepreneurship that I study.

In this model, the technological development occurs as variations in the environment. Each variation is an opportunity for a new firm but the specifics of the invention process is outside of the scope of this dissertation. Conditional on invention, the garage inventor then patents the technology having identified the possible opportunity. Then, different factors will 
affect the process after opportunity identification as the inventor decides to form a new venture or not in order to capitalize on the invention. Following this decision, the market acts as the retention mechanism and provides feedback whether the firm should continue to exist and how successful it will be. This leads to evaluating the selection mechanisms that expand the technological variations into entrepreneurial ventures.

Primarily, I am investigating the difference between the inventors who turned into entrepreneurs and those who did not. I develop the dataset initially from the USPTO patent grants to non-affiliated inventors. For example, during $1980-2009$, on average $15 \%$ of total patents are non-assigned. 


\section{CHAPTER 3: THEORY AND HYPOTHESIS DEVELOPMENT}

Entrepreneurship is based on identification and exploitation of opportunities (Shane and Venkataraman, 2000). The discovery or creation of a new technology creates the opportunity. Given the model under evaluation, the inventor has shown awareness of the opportunity but different factors can increase the awareness of market value and potential opportunity (Kirzner, 1973) or otherwise prompt the inventor to action in attempting to commercialize the technology (Mollick, 2012).

To answer the question of what factors prompts the garage inventor to become a garage entrepreneur (Amit, Glosten, and Muller, 1993), I first investigate characteristics of the social environment in which the potential entrepreneurs are embedded. I then develop arguments on the product and competitive environment at the time of the invention.

\section{Social Opportunity Space}

The types of resources a potential entrepreneur brings can be critical for firm survival and long-term success (Alvarez and Busenitz, 2001; Kerr, Kerr, and Nanda, 2015). Besides physical resources, the sociological foundations of entrepreneurship highlight the people, networks and institutional environment to which nascent entrepreneurs have access as critical drivers of action and ultimate success (Aldrich and Ruef, 2006; Nanda and Sørensen, 2010; Thornton, 1999). One of the important elements of networks is access to technical and market knowledge and experience. It is important to note that in this context, independent invention does not mean that the inventor is working alone or has never worked with other individuals. For this study, independent invention means that the inventor or inventors 
developed the technology outside of a work relationship with a firm, university or other organization that can claim ownership over the focal technology.

The focal invention is developed outside of these affiliations. However, it can be developed by a team or by individuals who have worked in teams prior to the focal independent technology. Leveraging knowledge gained from prior affiliations can help them overcome tacitness of external knowledge (Kogut and Zander, 1993), a valuable condition as most knowledge will be outside of the individual inventor without a formal affiliation. The knowledge required for successful innovations that are more likely to be radical and valuable as described above can therefore come from the size of the network even if not directly from the focal technology. For technologies actually developed by multiple inventors, each inventor can have unique knowledge and experiences (Gruber, MacMillan, and Thompson, 2013; Haas and Hansen, 2007).

If the inventors are strongly linked, the inventors will have access to nearly the same knowledge (Granovetter, 1973) and the invention could be limited in its value. However, if the inventors have different networks, one new path can open access to very different new knowledge that can be turned into value. As knowledge from different areas are recombined together, the likelihood of success increases. Focusing on more than just the size of the network, garage entrepreneurs will have networks of co-inventors with a variety of knowledge expertise. As the number of inventors increase, the likelihood of having new knowledge increases (Jones, 2009). Therefore, I hypothesize the positive effects of the size of the inventive network:

Hypothesis 1: Garage inventors are more likely to become garage entrepreneurs as they are professionally connected to more inventors. 


\section{Technological Opportunity Space}

"I fear someone in a garage who is devising something completely new."

Bill Gates (1998: as described by Grossman, 2012) in response to a question as to which competitor he feared most.

The innovative process is frequently seen as recombining prior knowledge in order to achieve novel combinations (Schumpeter, 1934; Spender and Grant, 1996). Incumbent firms are more likely to start working on process innovations (Cohen and Klepper, 1992, 1996a) and produce technological innovations that are very similar to their existing technologies (Helfat, 1994). Opportunities can also exist when actors specifically hold different views on the value of the technology. Even if incumbents were aware of a potential technological opportunity, they may not pursue it because they do not understand the importance of the technology - which will be more difficult as the technology becomes more radical and harder to evaluate - or that it is not economically important for them.

New technological categories are likely to emerge from new and small firms (Prusa and Schmitz Jr., 1991). Partially, this could be a function of the selection mechanism by inventor/entrepreneurs. Regardless of the technologies the independent inventors actually create, they are more likely to evaluate the opportunity as important if the idea is radical and potentially significant (Gans et al., 2002). If the idea is simple, inventors may recognize some small value but will not pursue the technology commercially. Additionally, incremental innovations that are not radical are more likely to be tied to existing technologies that are controlled by the existing incumbent firms. This will discourage inventors either cognitively as they evaluate the opportunity or rationally as they understand that the complementary products are not under their control and they will have a difficult time selling 
the enhancement. Entrepreneurs are also more likely to commercialize inventions themselves as the scope of the patents increases (Nerkar and Shane, 2007; Shane, 2001a). Under conditions of broad technological application, the opportunities will increase as the inventor can see markets in different areas (Shane, 2000) that the technology can be applied. Altogether, these arguments suggest that radicalness and significance of the technology will increase the rate of entrepreneurship amongst garage inventors.

Small, entrepreneurial firms, especially those started by independent inventors, will not have significant amounts of excess resources in order to compete broadly. They are best able to enter when small, niche market opportunities are available (Gans and Stern, 2003; Katila and Shane, 2005). By targeting niche markets, the independent inventors will be able to gain experience and perfect their products while not experiencing the full competitive pressures (Christensen, 1997). As the availability of niche markets increase, even if incumbent firms identify the opportunity, they may not see the profitability compared to their existing market (Bhide, 1992; Christensen and Bower, 1996). As the market concentration increases, existing firms will be more competitive and likely to respond to external events (Turner, Mitchell, and Bettis, 2010). With such concentration, independent firms may not be able to identify the market opportunities for smaller technological products.

Higher fragmentation creates more ambiguity in the market, an area where startups can maneuver to find a competitive position. Market segmentation is related to customers' willingness for differentiation (Shane, 2001b). Some technologies will allow different attributes to be highlighted from different firms. In established technological industries, firms will follow the product characteristics valued by their large customers, allowing the possibility for niches to exist for small firms (Christensen, 1997). 
These niches may exist as a large number of competitors are present in the environment (Katila and Shane, 2005) and similarly when the industry concentration is small (Nerkar and Shane, 2003). Niches are particularly relevant as incumbents are not able to serve the fringe users and new companies can test their products with little direct competition (Malerba et al., 2007). Therefore, I hypothesize that the presence of market niches, or areas of less competition for inventors, will be related to inventors starting new ventures to commercialize their inventions.

Hypothesis 2: Garage inventors are less likely to become garage entrepreneurs as the competition in the technological space increases.

\section{Geographical Opportunity Space}

Another sociological factor includes the startup activity in the area (Konczal, 2013). As the amount of startup activity in the area increases, entrepreneurship is more likely to be visible as their friends or colleagues start to engage in entrepreneurship (Kacperczyk, 2013; Roach and Sauermann, 2015). With increased startup activity, specialized resources dedicated to supporting such activity could increase which will allow for easier access by other potential startups.

With a large amount of entrepreneurship in an area, it is also more likely that the inventor is connected with someone who has entrepreneurial experience. This connection will help encourage entrepreneurship as connections will demonstrate to the inventor that starting his or her own business is an option for the technology (Roach and Sauermann, 2015). These connections can serve to evaluate the ideas for entrepreneurial potential and directly connect the inventor with other necessary resources. 
Even without the direct connection, a wave of entrepreneurship in the area can equally serve to encourage the inventor to consider firm formation (Freeman, 1986; Thornton, 1999). This has been seen similarly in acquisition waves (Stearns and Allan, 1996; Thornton, 1995). The startup activity and social pressures can serve to promote entrepreneurship regardless of the actual quality difference in the invention. Therefore, I suggest that startup activity will increasingly promote entrepreneurship from the set of garage inventors.

Hypothesis 3: Garage inventors are more likely to become garage entrepreneurs as incidence of entrepreneurship in their geographical area increases.

\section{Experience}

Entrepreneurial opportunities exist when the existing actors having different ideas of the potential value of an opportunity (Kirzner, 1973), are cognitively not able to recognize the opportunities, possibly because of their existing knowledge structure (Shane, 2000), or when the opportunities are created by luck or foresight through the recombination of previous ideas (Schumpeter, 1934).

Social and organizational connections serve to cull ideas earlier (Singh and Fleming, 2010) and provide feedback as new ideas develop. Without such connections, the alternative is for the inventor to develop the ideas and obtain feedback once new technologies are developed. This process of experiential learning increases the skill at patenting good technologies, claiming the required technological area to allow the inventor to commercialize it later. The feedback also improves the product that the inventor is providing before the inventor makes the decision to start a new firm with his existing technological portfolio. 
Further, organizations are repositories of technologies, associated resources, and stored and tacit knowledge accumulated over time related to their technological portfolio (Spender and Grant, 1996). A single independent patent defines the start of a technological trajectory but the inventor will need a fuller portfolio in order to increase their confidence of survival and economic viability (Somaya, 2012). Therefore, as an inventor both improves on the technology and builds a thicket of patents more capable of protecting the technological area, thereby increasing expected economic returns, the inventor is more likely to engage in entrepreneurship:

Hypothesis 4: Garage inventors are more likely to become garage entrepreneurs as their inventive experience increases. 


\section{CHAPTER 4: DATA AND METHODOLOGY}

In order to study the phenomenon of technological entrepreneurship by garage inventors, I study the transition from inventor to entrepreneur by operationalizing a garage inventor as an inventor in the patent database whose first patent is independently owned by the focal inventor and he or she has no recorded working history with an existing organization from the patent database. This is likely to capture those firms that have the potential to be vibrant additions to the economy. Patents have been shown as valuable resources for entrepreneurial companies (Hsu and Ziedonis, 2013) and as able to increase likelihood of receiving venture capital funding (Hsu, 2006; Stuart, Hoang, and Hybels, 1999).

\section{Sample and Data}

Using the Harvard Patent Dataverse (Lai et al., 2013) from 1980 to 2010, I identify the individuals who develop their first patent without an organizational assignee. This data is useful as it was designed to disambiguate inventors specifically to enable the study of inventor mobility in the database (Marx, Strumsky, and Fleming, 2009) which is similar to identifying the transition from independent inventor to entrepreneur. Figure 2 represents the trend of independent inventors patenting within the USPTO during a sample of the time under analysis for this dissertation.

Since the goal of my study is to understand the entrepreneurship founding process, use of a longitudinal panel could create an issue of sampling on the dependent variable, leading to issues with the validity of the results. As such, I follow the studies of Ahuja and 
Lampert (2001) and Nerkar and Paruchuri (2005) by following the entire cohort using a hazard model to allow censoring in yearly spells.

Censoring in this case represents right censored data whereby the entry is known but the exact exit point for the inventor is unknown. Once an inventor becomes an entrepreneur, the exit event is clear. Alternatively, I remove inventors after 20 years from the date of their last patent. After such a time, I have reasonable confidence that they are unlikely to start a firm based on the technology. Not only has a significant amount of time passed but per the legal timeline of the patent grant, their patent has expired. If the technology had value, the inventor no longer has an exclusivity right. While the model could be run as true continuous time, the yearly spells allow for updating the independent variables that vary with time for the inventor. Therefore, any year that ends with no known entrepreneurship event, the inventor is said to be right-censored. The inventor is therefore still in the analysis but the research methodology then allows me to empirically deal with their presence but unknown outcome. This is therefore different from clearly saying that inventor has not founded a firm. Censoring allows for such a distinction empirically.

I follow patenting inventors without corporate pre-history who applied for at least one granted patent after 1980. With a patenting pre-history to 1975, I can examine their background and history as well as have a robust timeline to follow their future career. This results in an initial risk-set of just under 190,000 technologies by nearly 225,000 unique garage inventors in the United States, which could be used to form a new venture. I develop the method to track the garage inventors and their subsequent patents to understand which were later owned by a new venture. Table 1 presents high-level statistics representing the patent database and garage inventor. 
The Appendix highlights the part of the process of evaluating firms as brand new entities and providing secondary verification on their founding. After initially matching the data the first-level identification strategy described above, I had a sample of 7,732 new firms in the USPTO data associated with inventors whose first patent had been unassigned to any organization. I went through the list to eliminate assignments that did not match the idea of a new, entrepreneurial firm. Namely, many were assigned to another inventor, especially when multiple inventors were on the patent but it would be owned by one in particular. Some universities' first patents were present in this sample and were thus eliminated. Foundations, trusts, institutes, and government organizations were removed if they were one of the new patenting organizations. Some international companies with GmbH (Germany) or SpA (Italian) with American inventors were also present and therefore removed. After this process, I was left with 5,780 firms. In the final analysis that relies on full data availability, I have a complete sample of 5,684 new firms in the patent database and 152,092 unique garage inventors.

Without controlling for any characteristics, the cumulative firm foundation percentage is presented in Figure 3. The percentage is scaled based on the inventors in the data set that $d o$ start an entrepreneurial firm, not on the total population of inventors. If scaled to the entire garage inventor list, the figure would asymptote to about $4 \%$. From the figure, we can see that $20 \%$ of inventors who start a new firm will do so in the same year as their initial parent. Within five years after the garage patent, $85 \%$ of those who will become entrepreneurs have done so. While I will eventually discount inventors who become entrepreneurs after 20 years, the figure also demonstrates that it is just under $100 \%$ of the future founding entrepreneurs at the expiration of their initial patent. 


\section{Model Specification}

I used a Cox Proportional Hazard Model of the form:

$$
h_{i}(t)=\lambda_{0}(t) \exp \left\{\beta_{1} x_{i 1}+\cdots+\beta_{k} x_{i k}\right\}
$$

where the baseline hazard function is left unspecified and the results are relative to this unknown and unspecified function. Between two individuals, the ratio of hazards is then:

$$
\frac{h_{i}(t)}{h_{j}(t)}=\exp \left\{\beta_{1}\left(x_{i 1}-x_{j 1}\right)+\cdots+\beta_{k}\left(x_{i k}-x_{j k}\right)\right\}
$$

Further the $\lambda_{0}(t)$ cancels out in the ratio. The analysis then tests a set of covariates on the risk of an event happening - the garage inventor engaging in entrepreneurship by patenting under a new technological entity.

The data is structured as survival analysis with a yearly outcome. I follow every inventor who applied for a patent 1980 onward under the proposed garage status in this study. In each year, I can specify their likelihood of patenting with a new technological entity, whether or not they patent in the following year. This also allows us to incorporate censoring for non-patenting in the outcome year.

Independent variables are defined by the characteristics of the inventor, the patent, or the environment in the year prior to the dependent variable. For yearly changing of independent variables, the outcome variable is always measured the year after the independent variable. This lag separates the characteristics of the technological area as an input from the output characteristics. I do not reset the inventor's status mid-year to allow multiple positive outcomes in a year (i.e., if the inventor files for a garage entrepreneurial patent in January and November of 2000, the outcome would still be one for positively patenting under a garage entity in 2000). While there are some repeat garage entrepreneurs, I remove them from the analysis once they become an entrepreneur. Alternatively, they are 
removed from the analysis 20 years after their last active patent has been filed. This is the length of patent validity and thus highly unlikely that they would rejoin the analysis with any characteristics resembling the expired patent. A simplification of the structure of the data used in the survival model is presented in Figure 4.

\section{Dependent Variable}

Garage Entrepreneurship: The dependent variable denotes whether the garage entrepreneur patents with a new technological entity in the focal year. A new technological entity is the first occurrence of the assignee in the Harvard Patent Dataverse (Lai et al., 2013) as defined by the asgnum indicator which incorporates the NBER (Hall, Jaffe, and Trajtenberg, 2001) pdpass into their own fuzzy string algorithm for disambiguation. This is similar to a definition used by Malerba and Orsenigo (1999) broadly on technological entry in new classes in the European patent data but is being applied to the first patent ever by a firm. Only the very first patent instance of the assignee is considered the entrepreneurial event and I consider any inventor on that patent to be the entrepreneur on record. If the garage inventor is associated with such a patent, then the dependent variable in the hazard model is triggered. All other outcomes including non-patenting, filing another independent patent, or filing a patent under an existing organization are considered censored events. No characteristics of the entrepreneurial patent are used for the analysis other than its presence or absence and independent variables are not updated when the patent is developed.

\section{Independent Variables}

For all variables, independent and dependent, patents were classified as occurring in the application year of the patent when determining the timing and characteristics for each variable. 
Number of Inventors: The first independent variable is the number of inventors on the patent under analysis. The "garage" status is defined at an inventor level while each patent may have multiple inventors and the analysis is done at the inventor level. Once an inventor has a patent, this is a time-invariant characteristic in the hazard model until the inventor develops a further patent. If the inventor develops a further patent, the characteristic is immediately updated on the basis of his most recent patent and is used going forward. If more than one inventor has "garage status" on the patent, then the first listed inventor is used.

Other Unique Inventor Ties: This variable is the number of unique inventors directly connected to the team of inventors prior to the patent under analysis. For a patent with one inventor, this represents the total number of other inventors he has worked with prior to this event. For a patent with a team of inventors, this is the cumulative unique inventors, separate from the focal team, that are connected to the inventors on this patent. Together with Number of Inventors, these variables represent a first and second degree strong social connection through which knowledge and information can be transferred. This variable is only updated with the generation of further patents with different network ties.

Inventor Experience: Experience is measured in the cumulative number of successful patent applications by the focal inventor. This is automatically set as the value from the previous year until a new patent is developed, at which time the variable is updated through the end of the current observation spell. This value is transformed for the model as ln(experience).

Firm Herfindahl: To operationalize the concentration in the technological opportunity space, I utilize the Herfindahl index (HHI) of firm patent ownership in the primary patent technological class. The Herfindahl index was originally used to calculate 
market share for competition and antitrust law but has also been used for technology management. I create the Herfindahl index by examining the 'market share' of the different assignees in the technological space in a given year. A higher Herfindahl index would suggest that a few firms are dominant in the technological area. For this analysis, I multiply the traditional calculation by ten in order to scale the variable from 0 to 10 to have a finer understanding of the concentration, especially for interpreting results. The calculation for $\mathrm{HHI}$ is:

$$
H H I_{i t}=\sum_{j=1}^{J}\left(\frac{n_{i j t}}{N}\right)^{2} * 10,
$$

where $i$ is the primary technological class and $j$ is each existing organization that patented in that technological area in year $t ; n$ is the number of patents assigned to the organization and $N$ is the total number of patents.

Independent Inventors in Technological Area: The complement of current competition in the technological area is the potential competition in the technological area. Especially from the perspective of a current independent inventor evaluating the technological opportunity, the inventor can determine how many potential entrants there are by the number of patents assigned to independent inventors - those that are similar to him have the potential to become an entrant. This variable is measured as the log transformed number of independent patents in the technological area in the previous year.

Previous Affiliation: The dummy variable where one in previous affiliation recognizes whether an inventor has, at that point in time, ever patented with an existing organization and zero represents never having been affiliated with an organization up to the analysis time. Every inventor under this analysis started his or her patenting career 
independent of any organization. However, it is possible for garage inventors to join an existing organization prior to becoming an entrepreneur. This dummy captures the transition to employee that may bring resources that non-affiliated inventors still do not have.

Size of Previous Affiliations: To further understand the significance of any prior organizational affiliations, this variable measures the maximum size of any prior organizational affiliation as calculated by the log of the number of patents owned by the organization at the time of inventor affiliation. Once an inventor works with a corporate affiliation, this becomes a stable characteristic of the inventor for all future observation spells. Depending on which regression model, this is valued at zero if the inventor has no prior organizational affiliation or is left out of the model as blank when evaluating organizational affiliation separate from the whole sample.

Venture Capital Deals in the State: One defining characteristic of the geographical opportunity space is the potential for outside funding which is a significant indicator for technological firms in particular (Hsu and Ziedonis, 2013; Stuart et al., 1999). The data is collected by the National Venture Capital Association (Franklin and Taylor, 2015) and Thomson Reuters that records the information and makes it available in their Stats and Studies Yearbook. This variable is the log of the total number of venture capital deals in the inventor's state in the focal year.

MSA Entry Rate: Further representing the geographical area, the Census Business Dynamics Statistics (US Census Bureau Center for Economic Studies, 2015) allows measurement of aggregated business dynamics information on a yearly basis built from the confidential Longitudinal Business Database. The entry rate is measured at the Metropolitan Statistical Area (MSA) and provided by the BDS. It is originally calculated as 100 * 
(number establishments entering in the year divided by the average number of establishments in the MSA).

MSA Exit Rate: The exit rate is determined in the same way as the entry rate but is measured as $100 *$ (the number of establishments that exited the area divided by the average number in existence in the year). Research highlights the opportunity for new firm development based on the closing of existing firms, unintentionally allowing existing firms to spin off their knowledge as entrepreneurial firms (Carnahan, 2013; Hoetker and Agarwal, 2007).

Time Since Invention: This variable is measured in years since the inventor's last patent. The Hazard Model tests the age of the patent and this time-based likelihood of engaging in technological entrepreneurship.

\section{Controls}

Additionally, I control for a few additional characteristics that are related to the independent variables or are theoretically relevant to the experience of the inventors:

Claims: This is the log of the number of claims on the patent. Claims has been used as a proxy for the significance of the technology and is correlated with the economic value (Nerkar and Paruchuri, 2005; Tong and Frame, 1994).

Five-year Citations: Both as a possible measure of significance and as a feedback mechanism, I include a rolling five-year citation rate indicating the total number of citations in the last five years that the inventor's patents have received prior to the focal year. This measure proxies for technological significance (Ahuja and Lampert, 2001) and offers the inventor feedback as to how and in what way other entities are using the inventor's technology. 
Originality: The originality is a characteristic of the technology defined by the nature of the references on the patent (Hall et al., 2001) which represents the concentration of technological classes in the backward citations of the patent:

$$
\operatorname{Originality~}_{i}=1-\sum_{j}^{n_{i}} s_{i j}^{2},
$$

where $s_{i j}$ denotes the percentage of citations made by patent $i$ that belong to class $j$. This is similar to the Herfindahl index and describes how broadly this technology connects to different technological areas. This is a time-invariant characteristic but is updated if the inventor develops a further patent.

Backward Citations: The number of backward citations is a relevant control with the originality measure and is another indicator of the amount of knowledge recombined in the focal technology (Fleming, 2001). This is a time-invariant characteristic but is updated if the inventor develops a further patent.

Male: The gender of the inventor is determined by matching the inventor name and year to the Social Security Administration data on social security applications in each year. (Social Security Administration, 2014). Patenting is predominantly performed by males (Hunt et al., 2013) and gender may affect the decision to engage in entrepreneurship following the invention and patenting (Delmar and Davidsson, 2000; Kuppuswamy and Mollick, 2015).

New Firms in Database: The nature of new startup firms may have a time-varying nature specific to technological firms and the patent database. The $\log$ of $(1+$ number of new firms in the entire patent database) in that year is included as a control for the market trends in entrepreneurship in general and the manner in which such firms were started in the patent 
database. This measures the number of new firms regardless of inventor garage status or whether those firms were directly measured as an outcome for this study.

Lawyer: As a proxy for resources, the lawyer variable is a dummy indicating whether the inventor utilized a lawyer to file the patent. This expense is not strictly required and the lawyer information is included on the patent. This data is available for all patent grants from 1998 onward and is from the Harvard Patent Dataverse (Lai et al., 2013).

Zillow Estimate of Home Value: Lastly, as another proxy for resources available to the potential entrepreneur (Jensen, Leth-Petersen, and Nanda, 2015; Kerr et al., 2015), the estimate of the inventor's personal home was collected using the inventor address and the website Zillow.com which proceeds home value estimates as well as general market conditions over time (Zillow.com, 2015). Home values for the set of garage inventors who started their careers in 2005 were collected and the value of the house fluctuated on the basis of local conditions in the zip code of the inventor. 


\section{CHAPTER 5: RESULTS}

The main summary statistics are presented in Table 2 . The correlations are presented in Table 3 and Table 4. The variables presented below are the primary independent variables. Most count variables will be logged due to the skewness present in their distributions.

\section{Summary Statistics}

A second set of summary statistics is presented in Table 5 that presents the summary statistics based on entrepreneurship condition. Part of this study is to document and explore the entrepreneurial activity in the patenting database in general related to garage inventorship. Table 6 and Figure 5 through Figure 8 help visualize the location of garage inventors and entrepreneurs representing the total number of inventors or entrepreneurs, respectively, in the state between 1980 and 2009 or the number weighted by the average population of the state during this timeframe. Again, garage inventors are counted if their first patent in the USPTO database is independent of an assignee organization. The garage entrepreneur data is based on the definition within this dissertation of the subset of garage entrepreneurs who subsequently produce the first patent for a brand new assignee within the USPTO data. California, New York, Florida, and Texas are the most prominent areas by raw number of both inventors and entrepreneurs. When weighted by population, New York, Virginia, Massachusetts, New Jersey, Alabama, and North Carolina are the top six inventorship areas with a rate above 2,000 garage inventors per million residents. Finally, New York, Virginia, Massachusetts, and New Jersey, all have a rate of garage entrepreneurs 
above 150 per million residents; and North Carolina, Wisconsin, Alabama, Arizona, Utah and Mississippi all have a rate of garage entrepreneurs above 50 per million residents.

\section{Main Results}

The Cox Proportional Hazard Model is a continuous time model that relates how the risk of an event - in this case, the patenting under a new technological entity - to the underlying hazard function (Allison, 1995). Hazard rates relative to the baseline are presented. To obtain the coefficients on the variables, calculate the natural $\log$ of the hazard rate (i.e., for Inventor Experience in Model 1, the coefficient would be $\ln (2.068)=0.727$ ). This is a proportional hazard rate where a value above 1.0 represents an increased likelihood of the event occurring and a value below 1.0 represents a decreased likelihood of the event happening.

Table 7 presents the results of the Cox Hazard Models with Model 1 representing the full analysis period from 1980-2009. I present the asterisks for reference but the tables also contain standard errors to help further understand significance levels (Bettis et al., 2016).

The Number of Inventors is positive with an odds ratio of 1.194 ( $s e=0.008$, $p<0.001)$. As the number of inventors on the garage patent increases by 1 , the likelihood of the garage inventor becoming an entrepreneur increases by $19.4 \%$. Similarly, as the Prior Unique Ties of Inventors increases, the likelihood of becoming an entrepreneur increases by $15.7 \%$ (hazard ratio $=1.157$, se $=0.009, p<0.001$ ). Together, these highlight the positive effect of strong network ties in the social opportunity space, either through direct coinvention in the previous patent or indirect connections by the focal inventor's prior patenting history or the second-degree connections brought by the co-inventor. 
With regard to the technological opportunity space, the effects of current and potential competitors is most obviously noticed. The Herfindahl concentration is negative with a reduction in likelihood of just over $30 \%$ for a one unit change in the concentration in this industry. The Herfindahl index, usually presented from 0 to 1 was rescaled from 0 to 10 to highlight the gradations. Therefore, a unit change is equal to a $10 \%$ increase in concentration, reducing the likelihood of entry by a significant amount $(h r=0.692$, se $=$ $0.038, p<0.001)$. This represents the current competitive landscape in the technological space. Alternatively, garage inventors could look at the area and determine the potential competitors by including the number of garage inventors in their evaluation of the technological space. The log of the number of independent inventors in the technological space is negative and significant $(h r=0.890$, se $=0.014, p<0.001)$. As the number of potential entrants as independent inventors increases by one standard deviation, the likelihood of entrepreneurship reduces by $11 \%$.

Next, I evaluate the results for the opportunity space as defined by the inventor's geography. As the number of venture capital deals in the inventor's state increases by one standard deviation, the likelihood of the inventor generating an entrepreneurial patent increases by $3.5 \%(h r=1.035$, se $=0.009, p<0.001)$. This is not a direct measure of capital infusion to businesses but a proxy for financial capital that could be available in the area and interest in technological startups. This still shows a positive effect of the amount of interest in technology businesses around the entrepreneur. Next, as the rate of entry of new establishments in the inventor's MSA increases, the inventor is likely to become an entrepreneur with an increased risk of $2.4 \%(h r=1.024, s e=0.008, p=0.003)$. The exit rate of establishments in the inventor's MSA however is not significant $(h r=0.987$, 
$s e=0.012, p=0.309$ ), suggesting that the entrepreneurial event is not driven by the closing of existing local establishments. This dichotomy in particular highlights the positive benefits of entrepreneurial growth in the area of the inventor.

Next, I discuss the results of increase in experience for the garage inventors. Each inventor under analysis begins with a single patent and no previous organizational affiliations. As the inventor patents more technologies, they are significantly more likely to become entrepreneurs at a rate of $108 \%(h r=2.068, s e=0.056, p<0.001)$ as they increase their patent portfolio by one standard deviation. Next, if the focal inventors joins an existing firm, they are also more likely to spin back out and become an entrepreneur with an increased hazard of $94 \%(h r=1.936, s e=0.112, p<0.001)$. The characteristic of this process is also started to be tested as the size of the organization's patent store. Namely, as the number of patents owned by the organization increased by one standard deviation, the likelihood of becoming a garage entrepreneur decreases by $24 \%(h r=0.763$, se $=0.010$, $p<0.001)$. Lastly, the time since invention is negative with a hazard ratio of 0.935 $(s e=0.004, p<0.001)$. The likelihood of becoming an entrepreneur decreases with time, which matches the raw pattern seen in Figure 3.

Finally, I will discuss the control variables presented in the model. The first set control for various patent-level characteristics. The log of the number of claims on the patent increases the likelihood of the inventor generating an entrepreneurial patent by $37 \%$ ( $h r=$ 1.367, se $=0.023, p<0.001)$. The five-year citation rate of the garage patent does not significantly affect the entrepreneurial rate $(h r=0.999, s e=0.003, p=0.812)$. However, the originality score does increase the likelihood of become an entrepreneur by $27 \%$ ( $h r=$ 1.270, $s e=0.063, p<0.001)$. Each additional backward citation included in the original 
patent also slightly increases the likelihood of the inventor becoming an entrepreneur $(h r=$ 1.003, se $=0.001, p<0.001)$. Even despite the majority of patentees being male to begin with (91\%), males were $119 \%$ more likely to move forward toward entrepreneurship $(h r=2.185, s e=0.137, p<0.001)$ than females in this population. Lastly, the presence of new firms in the patent database in that year, representing further patenting and entrepreneurial activity in the times, also significantly increases the likelihood of the inventor producing an entrepreneurial patent by an increase of $198 \%(h r=2.975$, $s e=0.266, p<0.001)$ with a one standard deviation increase in the number of new firms in the year.

Note that about $4 \%$ of the subjects within this analysis become entrepreneurs $(5,684$ garage entrepreneurs out of the 152,092 garage inventors included in Model 1). This rate differs from the overall statistics presented in Table 1 based on the availability of data for the full model and decisions to cull as described in the methodology section.

\section{Subsample Analyses}

I run four more models to elaborate on the results of Model 1. Specifically, next I break out the analysis as Table 8 into Model 2 and Model 3, which separates inventors who, respectively, never become affiliated with an existing firm prior to their final results from those who do join an existing firm. Model 2 presents the analysis for the garage inventors who do not join an existing firm. The outcome is either an entrepreneurial event, triggering a 1 in the dependent variable, or censored, triggering a zero. Model 3 is for the subset of garage inventors who will join an existing firm at some point prior to their removal from the analysis. The majority of garage inventors (93\%) do not join an existing firm as they develop patenting experience. 
Model 2 mirrors the effects in model 1 but excludes the firm affiliation variables. Directionally, all the main effects operate in the same predicted manner. The main results are slightly more pronounced without those that will join a firm. For example, there is a slight increase in the importance of the inventor connections, a hazard ratio of 1.265 as compared to 1.194 previously, and inventor experience. A new co-inventor on the focal patent now increases the hazard to 1.265 ( $s e=0.006, p<0.001$ ). If one co-inventor is added, the likelihood of the non-affiliated inventors to become an entrepreneur increases by nearly $27 \%$ as compared to $19 \%$ in the full model. Similarly, a prior outside connection to the patenting team increases the likelihood of a garage inventor becoming a garage entrepreneur by $20 \%(h r=1.202$, se $=0.009, p<0.001)$ rather than $15.7 \%$ from Model 1 . These effects start to indicate the effects of the corporate affiliation in the other sample. The importance of inventive experience is slightly enhanced with a $120 \%$ benefit $(h r=2.196$, se $=0.070, p<0.001)$ while it was still a very strong $107 \%$ increase in the base model.

Model 3 is the subset of inventors who will become affiliated with an existing organization during their patenting career. This represents about $7 \%$ of the garage inventors from the initial sample. The main effect is that corporate affiliation after a garage invention but before the entrepreneurial decision mutes many of the other hypothesized effects. The number of inventors is now negative $(h r=0.952, s e=0.021, p=0.022)$, reducing the likelihood of becoming an entrepreneur by $5 \%$ as a direct co-inventor tie is added rather than the $19 \%$ positive effect in model 1 . Other second order ties is still positive but at a rate of $4.2 \%$ increase $(h r=1.042$, se $=0.020, p=0.033)$ rather than the initial results of $16 \%$. The technological competition space is no longer significant as measured by firm concentration or number of independent inventors in the area but still negative for the Herfindahl $(h r=0.835$, 
$s e=0.117, p=0,198)$. The total number of other independent inventors in the technological space is positive but with a $95 \%$ confidence interval that would range from 0.957 to 1.097 . Finally, inventor experience is still positive with a $65 \%(h r=1.648$, $s e=0.112, p<0.001)$ rather than $116 \%$ in the full model. For this model, I also highlight the size of the affiliation. As the firm size decreases, measured by the log of the number of patents at the time of affiliation, the more likely the initial garage inventor is likely to later become an entrepreneur by nearly $9 \%(h r=0.913$, se $=0.011, p<0.001)$. This suggests that inventors who join larger firms are more likely to stay with their new affiliation, whereas the smaller the firm, the more likely the inventor is to change organizations again, and particularly to a new patenting organization.

When split into the subsamples, $3.3 \%$ of the non-affiliated inventors will become entrepreneurs and $8.7 \%$ of those that start as garage inventors but then join an established firm are likely to spin back out again and become entrepreneurs in the sample. This could partially be seen by the previous affiliation variable in model 1 but is also present in the raw breakouts from the samples in Models 2 and 3.

Models 4 and 5, presented in Table 9, are designed to include proxies of personal financial resources available to the garage inventor. Model 4 includes the dummy lawyer indicating whether the inventor hired a lawyer to file the garage patent. This is not required for patents but could be valuable for the quality. This also demonstrates ability of the inventor to pay for a lawyer to guide them through the process and may indicate an increased preliminary motivation for a more formal business relationship later. The presence of a lawyer on a garage patent increases the likelihood of becoming an entrepreneur by $58 \%$ $(h r=1.579, s e=0.111, p<0.001)$ while qualitatively leaving all the main effects constant. 
This information is only available for patents granted after 1998 due to USPTO data availability on the measure and represents half of the initial set of garage inventors from Model 1.

Lastly, Model 5 consists of preliminary results looking at an alternative measure of resources that is not affected by the entrepreneurial intentions at the time of the first patent. Data was collected from the set of garage inventors who began their career in 2005. I was able to identify home value estimates for half of the 5,600 inventors under this condition. The estimate of the inventor's personal home, allowed to fluctuate each year based on the economic conditions in the inventor's home zip code, has some evidence for the positive relationship to transition into entrepreneurship $(h r=1.427, s e=0.369, p=0.100)$. Due to the extreme reduction in observations, statistical confidence intervals become quite large for nearly all the main effects, dropping below traditional statistical significance levels except for the prior connections of the patenting inventors.

\section{Alternative Specifications}

Two additional tests are completed to demonstrate the effects from Table 7. Table 10 presents the interactions included in the model. Models 2 and 3 (Table 8) split the sample but the majority of the inventors are still present in Model 2, resulting in loss of precision around estimates for those that join a firm. The full interaction model in Table 10 interacts with the main hypothesized variables with the move to an established organization and runs the full model. The interactions are included at the top for readability. All the main effects in Model 6 remain qualitatively the same, as seen in Model 2. However, the interactions highlight the organizational effects of the accumulated affiliation experience with much higher clarity and statistical confidence. One additional co-inventor on a focal patent within 
an existing organization now decreases the inventor's likelihood of becoming an

entrepreneur by $24 \%(h r=0.761, s e=0.016, p<0.001)$. An additional prior connection no longer helps the inventor as each additional prior connection decreases the likelihood a further $16 \%(h r=0.840$, se $=0.021, p<0.001)$. As the inventor becomes embedded in a network of co-authors and connections within an organization, he or she is less likely to spin back out. The interaction with inventor experience is negative but statistically insignificant $(h r=0.930$, se $=0.067, p=0.312)$.

Lastly, Model 7 in Table 11 is a time-series logistic analysis on the entrepreneurial outcome by an inventor. All previous models were Cox Proportional Hazard Models that serve to include base time and inventor effects to the rate and likelihood of the entrepreneurial event. Model 7 alternatively checks this dichotomous option.

Once again, all the effects are qualitatively the same and significance levels are similar for all the main variables. The number of inventors on the patent increases the likelihood by $19 \%$ (odds ratio $=1.193$, se $=0.008, p<0.001)$, which is right in line with Model 1. Prior Unique Ties increase the entrepreneurial likelihood by $14 \%$ (or $=1.140$, se $=$ $0.010, p<0.001)$ as compared to nearly $16 \%$ originally. The inventive experience is highly significant with a $146 \%$ increased likelihood (or $=2.457$, se $=0.052, p<0.001$ ), whereas it had a hazard rate of 2.068 originally. The previous affiliation is also significantly present in the logistic model with a 150\% increased odds $($ or $=2.491$, se $=0.134, p<0.001)$ as compared to the still original value of $94 \%$.

This model does not separate out the entry and exit rates in the same manner as Model 1, demonstrating an increased likelihood of entrepreneurship as the general entrepreneurship rate increase $(o r=1.022$, se $=0.007)$ but also as the rate of existing firms 
decrease or $=1.052$, se $=0.010, p<0.001)$. The results of this test brings back the theoretical possibility that it is not simply sociological causes of entrepreneurship or even positive externalities to entrepreneurial areas and resources that promote the transition. In this case, entrepreneurs may be able to attach themselves to potential cofounders as existing companies close down and employees, existing firm resources, and knowledge are released into the environment (Carnahan, 2013; Hoetker and Agarwal, 2007). 


\section{CHAPTER 6: DISCUSSION AND CONCLUSION}

\section{Contributions}

This dissertation started with the notable idea of the heroic "garage entrepreneur". The image pervades not only the entrepreneurship culture but also the broader American culture that even Cadillac has called on it and its entrepreneurs to represent their message stating "you never know what kind of greatness can come out of an American garage" (AutoMoby, 2013; Ecclestone, 2014). I use the broad construct to determine the ultimate definition of a technological entrepreneur who started through independent invention. This enables me to address entrepreneurship and technology strategy theory with clear data identification mechanisms.

This dissertation overcame some of the classic problems of entrepreneurship research (Low and MacMillan, 1988) by identifying an entrepreneurial risk-set for the level of analysis and suggesting different theoretical perspectives that affect the likelihood of becoming an entrepreneur. I started the study asking what factors are associated with the likelihood of a garage inventor becoming a garage entrepreneur, particularly proposing that the opportunity space that the inventor operates in is related to such a transition. Conditional on already having developed a garage technology in a particular technological space, the competitive conditions in that space motivate the inventor to transition to entrepreneurship. Particularly, if stronger, more concentrated firms operate in the space, the inventor is less likely to proceed to entrepreneurship. As the space increases in potential competition through other independent inventors, the garage inventor is also less likely to proceed. 
Next, the geographical area contributes to the opportunity space of the potential entrepreneurs. As entrepreneurship is "in the air" as measured by the rate of any type of establishment entry in the entrepreneur's geographical area, the garage inventor is more likely to transition to entrepreneurship through a patent with a new technological entity. This likelihood is not affected by the exit rate of establishments in the inventor's area. Further, as a meaningful metric for potential technological firms, as the number of venture capital deals in the state that the inventor lives increases, the inventor is also more likely to become an entrepreneur.

The third opportunity space, social structure, is also highly important in the transition from inventor to entrepreneur. The direct and indirect inventive connections that the focal garage inventor has contributes to the positive likelihood of becoming an entrepreneur.

Lastly, increased inventive experience increases the likelihood of becoming an entrepreneur. This is significant as it shows an alternative method of learning that may be present without the organizational affiliations traditionally identified.

This effect is highlighted more prominently when separating out the inventors who stay independent up to a possible entrepreneurial event as compared to those garage inventors who patent under an existing organization prior to the end of the analysis. Joining an existing organization substitutes the need for additional direct inventive connections and dampens the importance of second-order connections' increased personal patenting experience, while possibly providing market and competitive knowledge; thus, no longer making the technological competitive landscape visible from the patent database significant. Entrepreneurship and strategic management literature has highlighted the importance of prior organizational knowledge and connections (Agarwal et al., 2004; Agarwal and Shah, 
2014; Cheyre, Klepper, and Veloso, 2015) and experience (Wadhwa et al., 2009; Wadhwa, Freeman, and Rissing, 2008). This study contributes in that line highlighting the increased entrepreneurial likelihood of inventors following organizational affiliation. I also contribute further upstream by showing earlier technical experience through patenting that demonstrates skills and interest in the direction. I show that while there is double the likelihood of entrepreneurship for these inventors, it is driven by smaller companies first and reverses key effects such as network strength. Besides patents, another modern model of the metaphorical garage is also "makerspaces" where individuals come together, have spaces and mechanical and tooling resources and encourage each other to hack new solutions to problems (Aldrich, 2014).

\section{Limitations and Future Directions for Research}

This study is not without its limitations but also not without its opportunities. First, its generalizability is limited to technological entrepreneurship of this type. Namely, for those entrepreneurs who develop an idea and patent the technology without clear organizational direction. Patenting is expensive and takes skill itself. Only certain individuals will move forward in this direction. This was a strategic choice that provides a strong data-set but it is also very limiting for those who still have a solid technological idea but do not pursue this strategy. Additionally, it is most appropriate for technologies that are well-represented in patents. Stamps.com is one case in this dataset that was only possible after the Business Method patent category was established and legalized within the United States Patent and Trademark Office classification system. Other technologies, even those with established classes, may not be well represented in this data. 
The model within this dissertation treats the garage invention as if the inventor has been struck by lightning, recognizes the technology, but still does not know what to do with it as a business opportunity yet. I treat the garage invention as this exogenous event, the variation in the selection model. I use an identification strategy for invention and entrepreneurship self-contained within the USPTO database. This limits the sample of garage inventors to those who have a technology that can be patented and have the resources and initiative to do so, even when they have not created the new business yet. This is clearly undercounting the number of inventors who are developing ideas with business potential, even though those that are counted will be more likely to be stronger and highly valued (Hsu and Ziedonis, 2008, 2013) than the average venture. The identification of an entrepreneurial event also has its limitations. The assignee organization is new to the US Patent and Trademark Office but the second patent and the founding may not perfectly align. This also does not identify the garage inventors who do not file a second patent with a new technology but do indeed start a firm on the basis of the first patent, thus undercounting the rate of entrepreneurship within the sample.

While I have evidence of the clear distinction between the two events, this is not always the case. Within the random sampling of firms, $20 \%$ were founded prior to the inventor's garage patent. This presents the long-term opportunity to verify those who had pre-founded their firm and understand its effect on the empirical results. The question remains as to their motive for the first patent and the legal assignment decision that was made, particularly as they assigned a later patent to the pre-known organizational entity under their control. Future research can also continue the theoretical development to blend the invention development and entrepreneurial decision as they become more intertwined 
from the start and closer to the rational economic perspective of technological development and direction.

Additionally, this suggests that inventors in larger organizations with many coinventors and connections could become embedded and are then not spinning back out as entrepreneurs, at least for those who started as garage inventors. Alternatively, this study presents the possibility to further explore the small firm effect (Elfenbein, Hamilton, and Zenger, 2010; Marx and Kacperczyk, 2015), not only as the benefits of small versus large, but identifying individuals who may be making the informed decisions to learn from one type or another, either with the goal of technical knowledge or business knowledge.

With this identification, there is clear possibility to understand the antecedents of this joining-prior-to-launching decision and exploring other aspects of the benefits of different organizational structures, whether as independent inventors or within organizations, as originally proposed by Schumpeter $(1934,1942)$. Lastly, this dissertation assumes through the survival analysis that entrepreneurship through starting a new business is the main desired outcome and all other results are censored observations. While starting to look at the possibility of joining an existing firm, the inventors have options to license or sell the developed technology to make profits off their labor too. These also have entrepreneurial value and may have different performance implications, whether positive or negative, endogenous to nature and quality of the technology and demand opportunities.

\section{Implications}

This study started by recalling fundamental questions in organizational and entrepreneurship research - where do new organizations come from and who is at risk of founding those organizations? By identifying a clear risk-set of potential entrepreneurs - 
those inventors who independently own a patented technology - I am able to overcome the latter question to more directly answer the former. The focus of this study is the understudied area of independent inventors who have no prior organizational patenting experience, called "garage inventors" and their likelihood of becoming entrepreneurs.

I find that increased independent patenting experience and social connections can substitute for direct organizational affiliations in the likelihood of becoming an entrepreneur. Overall, the founding conditions around the technological, social, and geographical opportunity spaces are important in the transition from inventor to entrepreneur for the set of garage inventors identified in the USPTO patent database. 


\section{TABLES}

Table 1: Initial Statistics from Patent Data

\begin{tabular}{ccc}
\hline Description & Number & Note \\
\hline Unique garage inventors in the United States & 224,907 &
\end{tabular}

Unique patents created by garage inventors $\begin{array}{ll}188,613 & \begin{array}{l}\text { Some patents have multiple garage } \\ \text { inventors }\end{array}\end{array}$

Total patent/inventor records by garage inventors over their career 406,629 $\begin{aligned} & \text { On average, about } 2 \text { records per } \\ & \text { inventor }\end{aligned}$

Garage inventors who become associated with some firm

$22,988 \quad 10.2 \%$ of all garage inventors

Garage inventors who become associated with a new firm

$11,317 \quad 49 \%$ of those who work with a firm or $6 \%$ of all garage inventors 
Table 2: Descriptive Statistics

\begin{tabular}{llccccc}
\hline \multicolumn{1}{c}{ Variable } & Obs. & Mean & S.D. & Min & Max \\
\hline No. & Number of Inventors & 311613 & 1.68 & 1.39 & 1 & 33 \\
$(2)$ & Claims & 311532 & 14.12 & 12.39 & 1 & 683 \\
$(3)$ & Five-year Citations & 311613 & 1.44 & 4.05 & 0 & 395 \\
$(4)$ & Originality & 291180 & 0.37 & 0.29 & 0 & 1 \\
$(5)$ & Backward Citations & 291180 & 12.43 & 21.29 & 1 & 1132 \\
$(6)$ & Other Inventor Ties & 311613 & 0.79 & 1.86 & 0 & 50 \\
$(7)$ & Inventor Experience & 311613 & 3.33 & 7.47 & 1 & 207 \\
$(8)$ & Male & 298295 & 0.91 & 0.29 & 0 & 1 \\
$(9)$ & Firm Herfindahl *10 & 311564 & 0.27 & 0.46 & 0 & 10 \\
$(10)$ & Independent Inventors in Area & 311564 & 127.97 & 105.42 & 0 & 520 \\
$(11)$ & New Firms in Database in this year & 311564 & 8085.34 & 2861.33 & 86 & $1.24 \mathrm{E}+04$ \\
$(12)$ & Previous Affiliation & 311613 & 0.18 & 0.38 & 0 & 1 \\
$(13)$ & Size of any Previous Affiliation & 311613 & 522.67 & 3270.1 & 0 & $5.85 \mathrm{E}+04$ \\
$(14)$ & Venture Capital Deals in State & 274658 & 351.44 & 594.9 & 0 & 2948 \\
$(15)$ & MSA Entry Rate & 278960 & 11.75 & 2.11 & 4.6 & 33.3 \\
$(16)$ & MSA Exit Rate & 278960 & 10.5 & 1.57 & 4.9 & 28.7 \\
$(17)$ & Time Since Invention & 311613 & 11.18 & 8.08 & 0 & 29 \\
$(18)$ & Lawyer & 160075 & 0.84 & 0.37 & 0 & 1 \\
$(19)$ & Home Value Estimate & 3048 & 541000 & $1,100,000$ & 27,500 & $26,200,000$ \\
\hline
\end{tabular}


Table 3: Correlation Table (a)

\begin{tabular}{|c|c|c|c|c|c|c|c|c|c|c|c|}
\hline No. & Variable & (1) & (2) & (3) & $(4)$ & $(5)$ & (6) & $(7)$ & $(8)$ & (9) & $(10)$ \\
\hline (1) & Number of Inventors & 1.000 & & & & & & & & & \\
\hline (2) & Claims & 0.191 & 1.000 & & & & & & & & \\
\hline (3) & Five-year Citations & -0.005 & 0.039 & 1.000 & & & & & & & \\
\hline (4) & Originality & 0.124 & 0.133 & 0.023 & 1.000 & & & & & & \\
\hline (5) & Backward Citations & 0.170 & 0.167 & 0.006 & 0.196 & 1.000 & & & & & \\
\hline (6) & Other Inventor Ties & 0.501 & 0.167 & -0.043 & 0.098 & 0.093 & 1.000 & & & & \\
\hline (7) & Inventor Experience & 0.252 & 0.128 & -0.065 & 0.073 & 0.110 & 0.505 & 1.000 & & & \\
\hline (8) & Male & -0.009 & 0.036 & -0.007 & -0.009 & 0.017 & 0.015 & 0.041 & 1.000 & & \\
\hline (9) & Firm Herfindahl $* 10$ & -0.031 & -0.020 & -0.006 & -0.048 & 0.000 & -0.018 & -0.007 & -0.011 & 1.000 & \\
\hline (10) & Independent Inventors in Area & -0.079 & -0.029 & 0.042 & -0.081 & -0.019 & -0.072 & -0.066 & -0.031 & -0.266 & 1.000 \\
\hline (11) & $\begin{array}{l}\text { New Firms in Database in this } \\
\text { year }\end{array}$ & 0.138 & 0.184 & 0.029 & 0.183 & 0.051 & 0.162 & 0.119 & -0.036 & -0.109 & 0.217 \\
\hline (12) & Previous Affiliation & 0.509 & 0.218 & -0.066 & 0.144 & 0.162 & 0.544 & 0.423 & 0.048 & -0.030 & -0.123 \\
\hline (13) & Size of any Previous Affiliation & 0.239 & 0.060 & -0.028 & 0.060 & 0.017 & 0.337 & 0.308 & 0.025 & 0.024 & -0.100 \\
\hline (14) & Venture Capital Deals in State & 0.034 & 0.024 & 0.034 & 0.010 & 0.006 & 0.037 & 0.046 & -0.013 & -0.001 & -0.002 \\
\hline (15) & MSA Entry Rate & 0.045 & 0.056 & -0.083 & 0.006 & 0.023 & 0.100 & 0.101 & 0.042 & -0.007 & -0.040 \\
\hline (16) & MSA Exit Rate & 0.000 & 0.024 & -0.044 & -0.007 & 0.000 & 0.037 & 0.046 & 0.017 & -0.003 & -0.004 \\
\hline (17) & Time Since Invention & -0.085 & -0.138 & 0.144 & -0.132 & -0.063 & -0.104 & -0.012 & 0.000 & 0.038 & -0.044 \\
\hline (18) & Lawyer & 0.050 & 0.090 & -0.008 & 0.035 & 0.036 & 0.036 & 0.036 & 0.038 & -0.011 & -0.005 \\
\hline (19) & Home Value Estimate & -0.006 & 0.033 & 0.022 & 0.034 & -0.008 & 0.034 & 0.026 & -0.032 & 0.009 & -0.016 \\
\hline
\end{tabular}


Table 4: Correlation Table (b)

\begin{tabular}{|c|c|c|c|c|c|c|c|c|c|c|}
\hline No. & Variable & (11) & (12) & (13) & (14) & (15) & (16) & (17) & (18) & (19) \\
\hline (11) & $\begin{array}{l}\text { New Firms in Database in this } \\
\text { year }\end{array}$ & 1.000 & & & & & & & & \\
\hline (12) & Previous Affiliation & 0.196 & 1.000 & & & & & & & \\
\hline (13) & Size of any Previous Affiliation & 0.074 & 0.340 & 1.000 & & & & & & \\
\hline (14) & Venture Capital Deals in State & 0.084 & 0.038 & 0.005 & 1.000 & & & & & \\
\hline (15) & MSA Entry Rate & -0.037 & 0.108 & 0.032 & 0.091 & 1.000 & & & & \\
\hline (16) & MSA Exit Rate & 0.002 & 0.032 & -0.007 & 0.162 & 0.678 & 1.000 & & & \\
\hline (17) & Time Since Invention & -0.324 & -0.084 & -0.020 & 0.044 & -0.354 & -0.212 & 1.000 & & \\
\hline (18) & Lawyer & -0.008 & 0.100 & 0.023 & -0.023 & 0.023 & -0.001 & 0.018 & 1.000 & \\
\hline (19) & Home Value Estimate & -0.056 & 0.009 & -0.006 & 0.223 & 0.100 & 0.088 & -0.048 & 0.042 & 1.000 \\
\hline
\end{tabular}


Table 5: Descriptive Statistics by Entrepreneurship Condition

\begin{tabular}{|c|c|c|c|c|c|c|c|c|c|}
\hline \multirow[b]{2}{*}{ No. } & \multirow[b]{2}{*}{ Variable } & \multicolumn{4}{|c|}{ Garage Entrepreneur $=1$} & \multicolumn{4}{|c|}{ Garage Entrepreneur $=0$} \\
\hline & & Mean & Std. Dev & Min & Max & Mean & Std. Dev. & Min & Max \\
\hline (1) & Number of Inventors & 1.99 & 1.4 & 1 & 27 & 1.67 & 1.39 & 1 & 33 \\
\hline (2) & Claims & 16.44 & 13.53 & 1 & 195 & 14.06 & 12.36 & 1 & 683 \\
\hline (3) & Five-year Citations & 1.51 & 3.9 & 0 & 82 & 1.44 & 4.06 & 0 & 395 \\
\hline (4) & Originality & 0.38 & 0.29 & 0 & 0.9363 & 0.37 & 0.29 & 0 & 1 \\
\hline (5) & Backward Citations & 13.04 & 17.18 & 1 & 672 & 12.41 & 21.39 & 1 & 1132 \\
\hline (6) & Other Inventor Ties & 0.96 & 1.24 & 0 & 21 & 0.79 & 1.87 & 0 & 50 \\
\hline (7) & Inventor Experience & 2.76 & 4.6 & 1 & 207 & 3.34 & 7.53 & 1 & 207 \\
\hline (8) & Male & 0.95 & 0.22 & 0 & 1 & 0.91 & 0.29 & 0 & 1 \\
\hline$(9)$ & Firm Herfindahl & 0.24 & 0.42 & 0 & 10 & 0.27 & 0.46 & 0 & 10 \\
\hline (10) & Independent Inventors in Tech Area & 127.36 & 106.48 & 0 & 520 & 127.98 & 105.41 & 0 & 520 \\
\hline (11) & New Firms in Database in this Year & 8069.99 & 2745 & 822 & $1.24 \mathrm{E}+04$ & 8085.06 & 2864 & 86 & $1.24 \mathrm{E}+04$ \\
\hline (12) & Previous Affiliation & 0.18 & 0.39 & 0 & 1 & 0.18 & 0.38 & 0 & 1 \\
\hline (13) & Size of any Previous Affiliation & 130.84 & 1292 & 0 & $4.85 \mathrm{E}+04$ & 533.64 & 3308 & 0 & $5.85 \mathrm{E}+04$ \\
\hline (14) & Venture Capital Deals in State & 302.89 & 539 & 0 & 2948 & 352.84 & 596 & 0 & 2948 \\
\hline (15) & MSA Entry Rate & 12.95 & 2.13 & 7.6 & 33.3 & 11.72 & 2.1 & 4.6 & 33.3 \\
\hline (16) & MSA Exit Rate & 10.91 & 1.54 & 5.7 & 25.3 & 10.48 & 1.57 & 4.9 & 28.7 \\
\hline (17) & Time Since Invention & 5.95 & 4.99 & 0 & 28 & 11.33 & 8.1 & 0 & 29 \\
\hline (18) & Lawyer & 0.88 & 0.32 & 0 & 1 & 0.84 & 0.37 & 0 & 1 \\
\hline$(19)$ & Home Value Estimate & 647,000 & 482,000 & 112,000 & $2,300,000$ & 540,000 & $1,100,000$ & 27,500 & $26,200,000$ \\
\hline
\end{tabular}


Table 6: Garage Invention and Entrepreneurship Statistics by State

\begin{tabular}{|c|c|c|c|c|}
\hline State & Garage Inventors & $\begin{array}{l}\text { Garage } \\
\text { Inventors } \\
\text { per Million } \\
\text { Residents }\end{array}$ & $\begin{array}{c}\text { Garage } \\
\text { Entrepreneurs }\end{array}$ & $\begin{array}{l}\text { Garage } \\
\text { Entrepreneurs per } \\
\text { Million Residents }\end{array}$ \\
\hline Alabama & 1,629 & $2,779.47$ & 40 & 68.25 \\
\hline Alaska & 473 & 110.82 & 3 & 0.70 \\
\hline Arizona & 4,422 & $1,744.36$ & 149 & 58.77 \\
\hline Arkansas & 907 & 205.32 & 24 & 5.43 \\
\hline California & 33,651 & $1,079.07$ & 1,409 & 45.18 \\
\hline Colorado & 3,863 & $1,003.78$ & 189 & 49.11 \\
\hline Connecticut & 3,115 & 932.96 & 127 & 38.04 \\
\hline Delaware & 416 & 572.13 & 9 & 12.38 \\
\hline Florida & 13,072 & 909.44 & 376 & 26.16 \\
\hline Georgia & 3,753 & 509.94 & 143 & 19.43 \\
\hline Hawaii & 718 & 616.89 & 12 & 10.31 \\
\hline Idaho & 1,147 & 95.71 & 33 & 2.75 \\
\hline Illinois & 8,162 & $1,394.77$ & 281 & 48.02 \\
\hline Indiana & 2,991 & $1,036.21$ & 112 & 38.80 \\
\hline Iowa & 1,569 & $1,325.23$ & 47 & 39.70 \\
\hline Kansas & 1,615 & 624.66 & 60 & 23.21 \\
\hline Kentucky & 1,335 & 341.83 & 45 & 11.52 \\
\hline Louisiana & 2,873 & 655.09 & 90 & 20.52 \\
\hline Maine & 706 & 114.97 & 25 & 4.07 \\
\hline Maryland & 3,761 & 751.61 & 128 & 25.58 \\
\hline Massachusetts & 5,276 & $4,253.92$ & 237 & 191.09 \\
\hline Michigan & 7,737 & 806.37 & 278 & 28.97 \\
\hline Minnesota & 4,233 & 911.80 & 204 & 43.94 \\
\hline Mississippi & 7,737 & $1,439.75$ & 278 & 51.73 \\
\hline Missouri & 3,097 & $1,137.59$ & 112 & 41.14 \\
\hline
\end{tabular}


Table 6 (continued)

\begin{tabular}{ccccc}
\hline Montana & 800 & 921.85 & 29 & 33.42 \\
Nebraska & 1,080 & 940.59 & 29 & 25.26 \\
Nevada & 1,541 & 208.22 & 53 & 7.16 \\
New Hampshire & 1,077 & 133.43 & 47 & 5.82 \\
New Jersey & 6,662 & $3,977.78$ & 262 & 156.43 \\
New Mexico & 1,088 & 58.95 & 44 & 2.39 \\
New York & 13,427 & $20,594.70$ & 473 & 725.50 \\
North Carolina & 3,850 & $2,318.31$ & 150 & 90.33 \\
North Dakota & 524 & 321.72 & 14 & 8.60 \\
Ohio & 6,194 & 556.91 & 239 & 21.49 \\
Oklahoma & 2,241 & 668.97 & 65 & 19.40 \\
Oregon & 2,994 & 951.26 & 132 & 41.94 \\
Pennsylvania & 7,354 & 605.81 & 216 & 17.80 \\
Rhode Island & 635 & 624.28 & 17 & 16.71 \\
South Carolina & 1,820 & 483.16 & 65 & 17.26 \\
South Dakota & 451 & 615.08 & 16 & 21.82 \\
Tennessee & 2,506 & 470.87 & 73 & 13.72 \\
Texas & 11,419 & 596.75 & 412 & 21.53 \\
Utah & 2,156 & $1,069.44$ & 118 & 58.53 \\
Vermont & 482 & 72.86 & 23 & 3.47 \\
Virginia & 3,903 & $6,748.09$ & 151 & 261.07 \\
Washington & 4,599 & 858.70 & 174 & 32.49 \\
West Virginia & 607 & 118.05 & 15 & 2.92 \\
Wisconsin & 3,494 & $1,893.67$ & 148 & 18.20 \\
Wyoming & 417 & 843.26 & 9 &
\end{tabular}


Table 7: Results (a) - Cox Proportional Hazard Models

\begin{tabular}{lc}
\hline Description & Model 1 \\
& Full Model \\
\hline \multicolumn{1}{c}{ Main Independent Variables } & \\
& $1.194^{* * *}$ \\
Number of Inventors & $(0.008)$ \\
& $1.157^{* * *}$ \\
Prior Unique Ties of Inventors & $(0.009)$ \\
& $0.692^{* * *}$ \\
Firm Herfindahl (0-10) & $(0.038)$ \\
& $0.890^{* * *}$ \\
Total Independent in Tech Area (log) & $(0.014)$ \\
& $1.035^{* * *}$ \\
Venture Capital Deals in State (log) & $(0.009)$ \\
& $1.024^{* *}$ \\
MSA Entry Rate & $(0.008)$ \\
& 0.987 \\
MSA Exit Rate & $(0.012)$ \\
& $2.068^{* * *}$ \\
Inventor Experience (log) & $(0.056)$ \\
& $1.936^{* * *}$ \\
Previous Affiliation & $(0.112)$ \\
& $0.763^{* * *}$ \\
Size of Previous Affiliation (log) & $(0.010)$ \\
Time Since (years) & $0.935^{* * *}$ \\
\multicolumn{1}{c}{ Control Variables } & $(0.004)$ \\
& \\
Claims (log) & $1.367^{* * *}$ \\
Five-year Citations & $(0.023)$ \\
& 0.999 \\
Originality & $(0.003)$ \\
Backward Citations & $1.270^{* * *}$ \\
Male (=1) & $(0.063)$ \\
New Firms in Database (log) & $1.003^{* * *}$ \\
Observations & $(0.001)$ \\
Number of Subjects & $2.185^{* * *}$ \\
Log-likelihood & $(0.137)$ \\
& $2.975^{* * *}$ \\
& $(0.266)$ \\
& $1,975,063$ \\
& 5,092 \\
& -077.53 \\
\hline
\end{tabular}




$$
+p<0.10 ; * p<0.05 ; * * p<0.01 ; * * * p<0.001
$$

Standard errors in parentheses; Hazard Ratio presented

Cox Proportional Hazard Model regression with hazard rates presented. Outcome is the incident of generating a patent with a new technological firm in the year following the independent variables.

All other outcomes are considered censored in the model. To calculate coefficients, calculate $\ln$ (hazard rate). For example, the inventor experience variable coefficient in Model 1 would be $\ln (2.156)=0.768$. 
Table 8: Results (b) - Cox Proportional Hazard Models

\begin{tabular}{|c|c|c|}
\hline Description & $\begin{array}{c}\text { Model } 2 \\
\text { Non-affiliated } \\
\text { inventors }\end{array}$ & $\begin{array}{c}\text { Model } 3 \\
\text { Inventors who } \\
\text { become affiliated }\end{array}$ \\
\hline \multicolumn{3}{|l|}{ Main Independent Variables } \\
\hline Number of Inventors & $\begin{array}{r}1.265^{* * * *} \\
(0.006)\end{array}$ & $\begin{array}{r}0.952 * \\
(0.021)\end{array}$ \\
\hline Prior Unique Ties of Inventors & $\begin{array}{r}1.202 * * * \\
(0.009)\end{array}$ & $\begin{array}{r}1.042 * \\
(0.020)\end{array}$ \\
\hline Firm Herfindahl (0-10) & $\begin{array}{r}0.589 * * * \\
(0.039)\end{array}$ & $\begin{array}{r}0.835 \\
(0.117)\end{array}$ \\
\hline Total Independent in Tech Area (log) & $\begin{array}{r}0.856^{* * * *} \\
(0.015)\end{array}$ & $\begin{array}{r}1.025 \\
(0.035)\end{array}$ \\
\hline Venture Capital Deals in State (log) & $\begin{array}{r}1.039 * * * \\
(0.010)\end{array}$ & $\begin{array}{r}1.069 * * \\
(0.023)\end{array}$ \\
\hline MSA Entry Rate & $\begin{array}{r}1.019 * \\
(0.009)\end{array}$ & $\begin{array}{r}1.030 \\
(0.022)\end{array}$ \\
\hline MSA Exit Rate & $\begin{array}{c}0.978 \\
(0.013)\end{array}$ & $\begin{array}{r}0.983 \\
(0.033)\end{array}$ \\
\hline Inventor Experience (log) & $\begin{array}{r}2.196 * * * \\
(0.070)\end{array}$ & $\begin{array}{r}1.907 * * * \\
(0.100)\end{array}$ \\
\hline \multicolumn{3}{|l|}{ Previous Affiliation } \\
\hline Size of Previous Affiliation (log) & & $\begin{array}{r}0.913 * * * \\
(0.011)\end{array}$ \\
\hline Time Since (years) & $\begin{array}{r}0.924 * * * \\
(0.006)\end{array}$ & $\begin{array}{r}0.982 * \\
(0.007)\end{array}$ \\
\hline \multicolumn{3}{|l|}{ Control Variables } \\
\hline Claims (log) & $\begin{array}{r}1.427 * * * \\
(0.027)\end{array}$ & $\begin{array}{r}1.246 * * * \\
(0.053)\end{array}$ \\
\hline Five-year Citations & $\begin{array}{r}0.999 \\
(0.003)\end{array}$ & $\begin{array}{r}0.986+ \\
(0.008)\end{array}$ \\
\hline Originality & $\begin{array}{r}1.218 * * * \\
(0.066)\end{array}$ & $\begin{array}{r}1.375 * * \\
(0.168)\end{array}$ \\
\hline Backward Citations & $\begin{array}{r}1.006^{* * *} * \\
(0.001)\end{array}$ & $\begin{array}{r}1.003^{* *} * \\
(0.001)\end{array}$ \\
\hline Male $(=1)$ & $\begin{array}{r}2.451 * * * \\
(0.172)\end{array}$ & $\begin{array}{r}1.332+ \\
(0.198)\end{array}$ \\
\hline \multirow[t]{2}{*}{ New Firms in Database (log) } & $\begin{array}{r}3.086 * * * \\
(0.348)\end{array}$ & $\begin{array}{r}1.910 * * * \\
(0.317)\end{array}$ \\
\hline & $1,838,365$ & 136,698 \\
\hline
\end{tabular}


Observations

Number of Subjects

140,913

11,179

Number of Events

4,717

Log-likelihood

$-50,044.72$

967

$-8,245.02$

$+p<0.10 ; * p<0.05 ; * * p<0.01 ; * * * p<0.001$

Standard errors in parentheses; Hazard Ratio presented

Cox Proportional Hazard Model regression with hazard rates presented. Outcome is the incident of generating a patent with a new technological firm in the year following the independent variables.

All other outcomes are considered censored in the model. 
Table 9: Results (c) - Cox Proportional Hazard Models

\begin{tabular}{|c|c|c|}
\hline Description & $\begin{array}{c}\text { Model } 4 \\
1998 \text { onward }\end{array}$ & $\begin{array}{c}\text { Model } 5 \\
2005 \text { Model with } \\
\text { Home Value }\end{array}$ \\
\hline \multicolumn{3}{|l|}{ Main Independent Variables } \\
\hline Number of Inventors & $\begin{array}{l}1.145^{* * *} \\
(0.012)\end{array}$ & $\begin{array}{r}1.154 \\
(0.342)\end{array}$ \\
\hline Prior Unique Ties of Inventors & $\begin{array}{l}1.103^{* * * *} \\
(0.014)\end{array}$ & $\begin{array}{r}5.406^{*} \\
(4.026)\end{array}$ \\
\hline Firm Herfindahl (0-10) & $\begin{array}{l}0.795^{* *} \\
(0.066)\end{array}$ & $\begin{array}{r}1.486 \\
(0.986)\end{array}$ \\
\hline Total Independent in Tech Area (log) & $\begin{array}{l}0.896^{* * *} \\
(0.020)\end{array}$ & $\begin{array}{r}1.982+ \\
(0.773)\end{array}$ \\
\hline Venture Capital Deals in State (log) & $\begin{array}{l}1.042 * * \\
(0.013)\end{array}$ & $\begin{array}{r}1.087 \\
(0.226)\end{array}$ \\
\hline MSA Entry Rate & $\begin{array}{l}1.031^{*} \\
(0.015)\end{array}$ & $\begin{array}{r}0.998 \\
(0.194)\end{array}$ \\
\hline MSA Exit Rate & $\begin{array}{l}1.012 \\
(0.026)\end{array}$ & $\begin{array}{l}1.021 \\
(0.359)\end{array}$ \\
\hline Inventor Experience $(\log )$ & $\begin{array}{l}1.876^{* * *} \\
(0.068)\end{array}$ & $\begin{array}{r}0.000 \\
(0.000)\end{array}$ \\
\hline Previous Affiliation & $\begin{array}{l}1.972 * * * \\
(0.154)\end{array}$ & $\begin{array}{r}0.000 \\
(0.000)\end{array}$ \\
\hline Size of Previous Affiliation (log) & $\begin{array}{l}0.783^{* * * *} \\
(0.013)\end{array}$ & $\begin{array}{r}54.736 \\
(2.87 \mathrm{e} 10)\end{array}$ \\
\hline Time Since (years) & $\begin{array}{l}0.958 * * * \\
(0.006)\end{array}$ & $\begin{array}{r}0.000 \\
(0.000)\end{array}$ \\
\hline \multicolumn{3}{|l|}{ Control Variables } \\
\hline Claims (log) & $\begin{array}{l}1.270 * * * \\
(0.033)\end{array}$ & $\begin{array}{l}0.655 \\
(0.206)\end{array}$ \\
\hline Five-year Citations & $\begin{array}{r}0.993 \\
(0.005)\end{array}$ & $\begin{array}{r}1.304 \\
(0.233)\end{array}$ \\
\hline Originality & $\begin{array}{l}1.366^{* * *} \\
(0.105)\end{array}$ & $\begin{array}{l}8.618+ \\
(10.979)\end{array}$ \\
\hline Backward Citations & $\begin{array}{l}1.003 * * * \\
(0.001)\end{array}$ & $\begin{array}{r}0.986 \\
(0.024)\end{array}$ \\
\hline Male (=1) & $\begin{array}{l}1.811 * * * \\
(0.149)\end{array}$ & $\begin{array}{l}2.235 \\
(2.354)\end{array}$ \\
\hline New Firms in Database (log) & $\begin{array}{r}0.985 \\
(0.131)\end{array}$ & $\begin{array}{c}0.623 \\
(0.000)\end{array}$ \\
\hline Lawyer & $\begin{array}{l}1.579 * * * \\
(0.111)\end{array}$ & $\begin{array}{r}2.4 \mathrm{e} 16 \\
(0.000)\end{array}$ \\
\hline
\end{tabular}


Observations

658,241

Number of Subjects

$$
+p<0.10 ; * p<0.05 ; * * p<0.01 ; * * p<0.001
$$

Standard errors in parentheses; Hazard Ratio presented

Cox Proportional Hazard Model regression with hazard rates presented. Outcome is the incident of generating a patent with a new technological firm in the year following the independent variables.

All other outcomes are considered censored in the model. 
Table 10: Interaction Model with Post-Firm Affiliation (Cox Model)

Description
Model 6

Full Interaction Model

\section{Interacted Variables with Post-Firm Affiliation}

$x$.Number of Inventors

$0.761^{* * *}$

$(0.016)$

$x$.Prior Unique Ties of Inventors

$0.840^{* * *}$

$(0.021)$

$x$.Inventor Experience $(\log )$

0.930

$(0.067)$

$x$.Firm Herfindahl (0-10)

$1.505^{* *}$

$(0.224)$

$x$.Total Independent in Tech Area $(\log )$

$1.234 * * *$

$(0.042)$

$x$.Venture Capital Deals in State $(\log )$

$1.067 * *$

$(0.025)$

$x$.MSA Entry Rate

$1.040+$

$(0.022)$

$x$.MSA Exit Rate

0.979

$(0.028)$

\section{Main Independent Variables}

Number of Inventors

$1.257^{* * * *}$

$(0.007)$

Prior Unique Ties of Inventors

$1.191 * * *$

$(0.009)$

Firm Herfindahl (0-10)

$0.622 * * *$

$(0.039)$

Total Independent in Tech Area $(\log )$

$0.861 * * *$

$(0.014)$

Venture Capital Deals in State (log)

$1.028^{* * *}$

$(0.010)$

MSA Entry Rate

$1.018^{*}$

$(0.009)$

MSA Exit Rate

0.987

(0.013)

Inventor Experience (log)

$2.078^{* * * *}$

$(0.060)$

Previous Affiliation

$1.259 * *$

$(0.110)$

Size of Previous Affiliation (log)

$0.808^{* * *}$

$(0.013)$

Time Since (years) 


\section{Control Variables}

Claims $(\log )$

$1.371 * * *$

$(0.024)$

Five-year Citations

0.998

(0.003)

Originality

$1.242 * * *$

$(0.062)$

Backward Citations

$1.004 * * *$

(0.001)

Male (=1)

$2.235 * * *$

$(0.142)$

New Firms in Database $(\log )$

$2.982 * * *$

$(0.267)$

Observations

$1,975,063$

Number of Subjects

152,092

Number of Events

5,684

Log-likelihood

$-60,825.01$

$+p<0.10 ; * p<0.05 ; * * p<0.01 ; * * * p<0.001$

Standard errors in parentheses; Hazard Ratio presented

Cox Proportional Hazard Model regression with hazard rates presented. Outcome is the incident of generating a patent with a new technological firm in the year following the independent variables.

All other outcomes are considered as censored in the model. All subjects started as garage inventors but the $x$. variables refer to the interaction after some become affiliated to a non-entrepreneurial company. 
Table 11: Robustness Test - Logit Model

\begin{tabular}{|c|c|}
\hline Description & $\begin{array}{c}\text { Model } 7 \\
\text { Logit Model }\end{array}$ \\
\hline Number of Inventors & $\begin{array}{l}1.193 * * * \\
(0.008)\end{array}$ \\
\hline Prior Unique Ties of Inventors & $\begin{array}{l}1.140 * * * \\
(0.010)\end{array}$ \\
\hline Firm Herfindahl (0-10) & $\begin{array}{l}0.730 * * * \\
(0.037)\end{array}$ \\
\hline Total Independent in Tech Area (log) & $\begin{array}{l}0.920 * * * \\
(0.013)\end{array}$ \\
\hline Venture Capital Deals in State (log) & $\begin{array}{r}0.993 \\
(0.008)\end{array}$ \\
\hline MSA Entry Rate & $\begin{array}{l}1.022^{* * *} \\
(0.007)\end{array}$ \\
\hline MSA Exit Rate & $\begin{array}{l}1.052 * * * \\
(0.010)\end{array}$ \\
\hline Inventor Experience (log) & $\begin{array}{l}2.457 * * * \\
(0.052)\end{array}$ \\
\hline Previous Affiliation & $\begin{array}{l}2.491 * * * \\
(0.134)\end{array}$ \\
\hline Size of Previous Affiliation (log) & $\begin{array}{l}0.735 * * * \\
(0.009)\end{array}$ \\
\hline Time Since (years) & $\begin{array}{l}0.890 * * * \\
(0.003)\end{array}$ \\
\hline Claims (log) & $\begin{array}{l}1.340 * * * \\
(0.022)\end{array}$ \\
\hline Five-year Citations & $\begin{array}{r}0.998 \\
(0.003)\end{array}$ \\
\hline Originality & $\begin{array}{l}1.169 * * * \\
(0.055)\end{array}$ \\
\hline Backward Citations & $\begin{array}{r}1.000 \\
(0.001)\end{array}$ \\
\hline Male $(=1)$ & $\begin{array}{l}2.271 * * * \\
(0.134)\end{array}$ \\
\hline New Firms in Database (log) & $\begin{array}{r}1.013 \\
(0.039)\end{array}$ \\
\hline Observations & $2,209,321$ \\
\hline Number of Groups & 153,184 \\
\hline Wald $\chi^{2}$ & 9,058.89 \\
\hline Prob $>\chi^{2}$ & 0.00 \\
\hline
\end{tabular}

$* p<0.05 ; * * p<0.01 ; * * * p<0.001$

xtgee command in stata based on a time-series logistic analysis. Standard errors in parentheses; odds ratio presented; Event is a further patent with a garage entrepreneurial firm. 


\section{FIGURES}

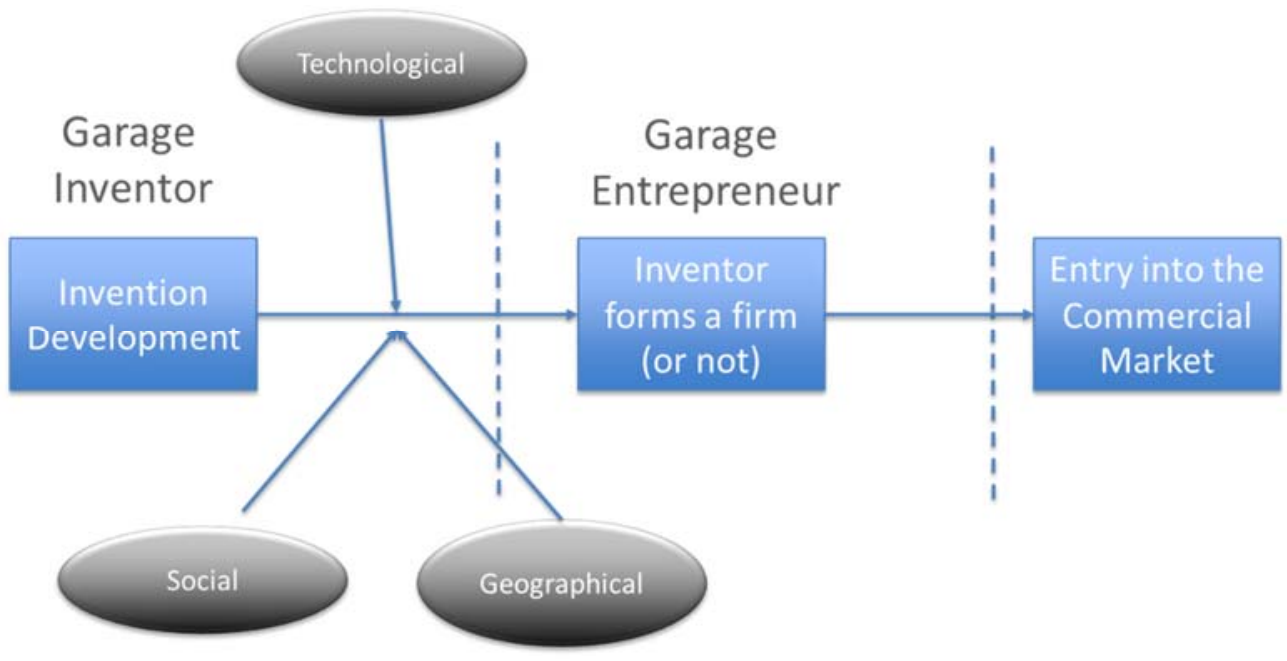

Figure 1: Basic Model of Garage Entrepreneurship ${ }^{1}$

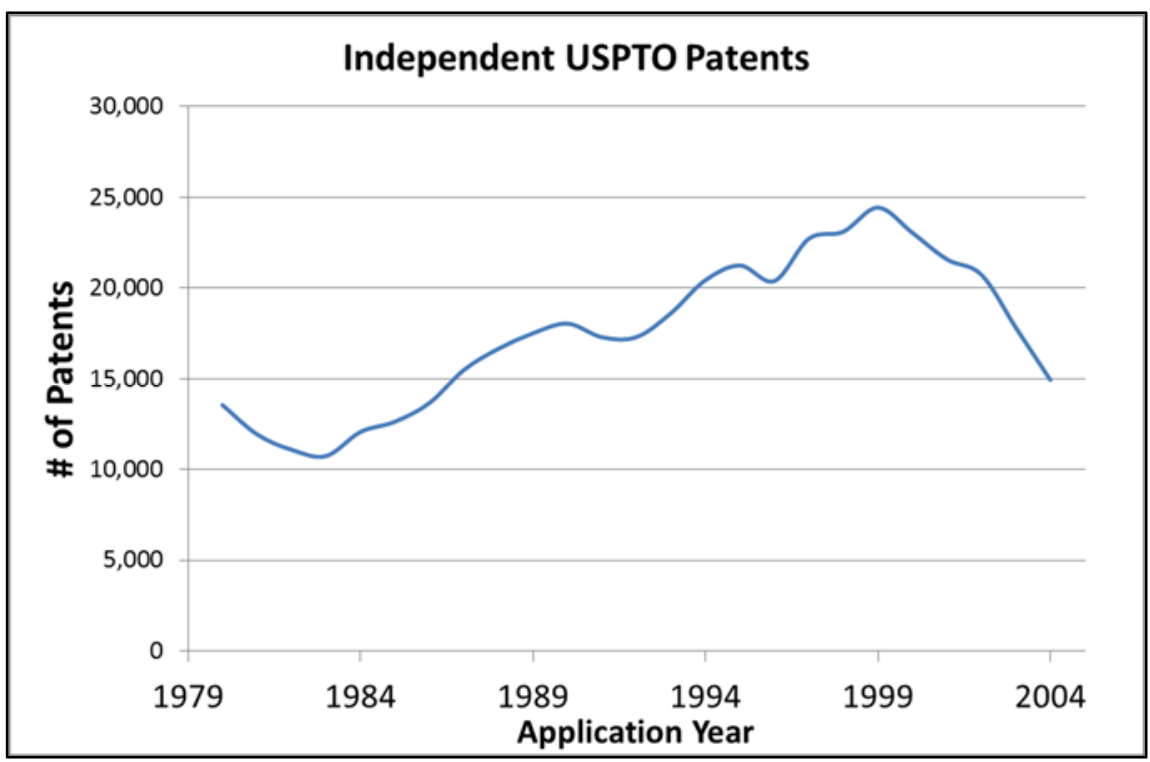

Figure 2: USPTO Patents by Independent Inventors: 1980-2004

${ }^{1}$ Adapted from the model with prior knowledge from Shane (2000) as well as the "User Entrepreneurship Model" in Shah and Tripsas (2007: 129) as compared to the "Classic Entrepreneurship Model" starting with Opportunity Identification, firm formation, and development of solution. 


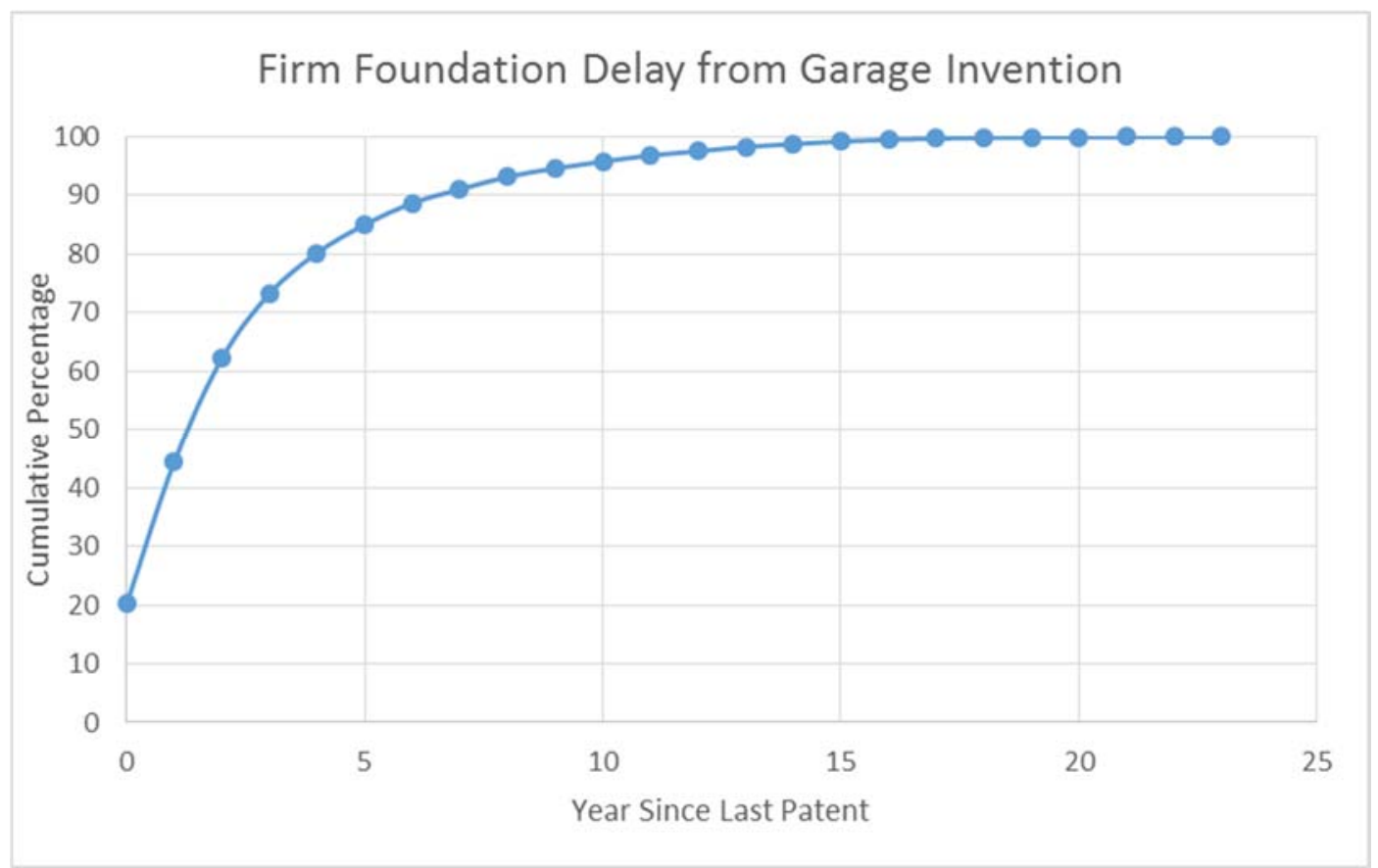

Figure 3: Firm Foundation Delay from Last Patent for Garage Inventors 


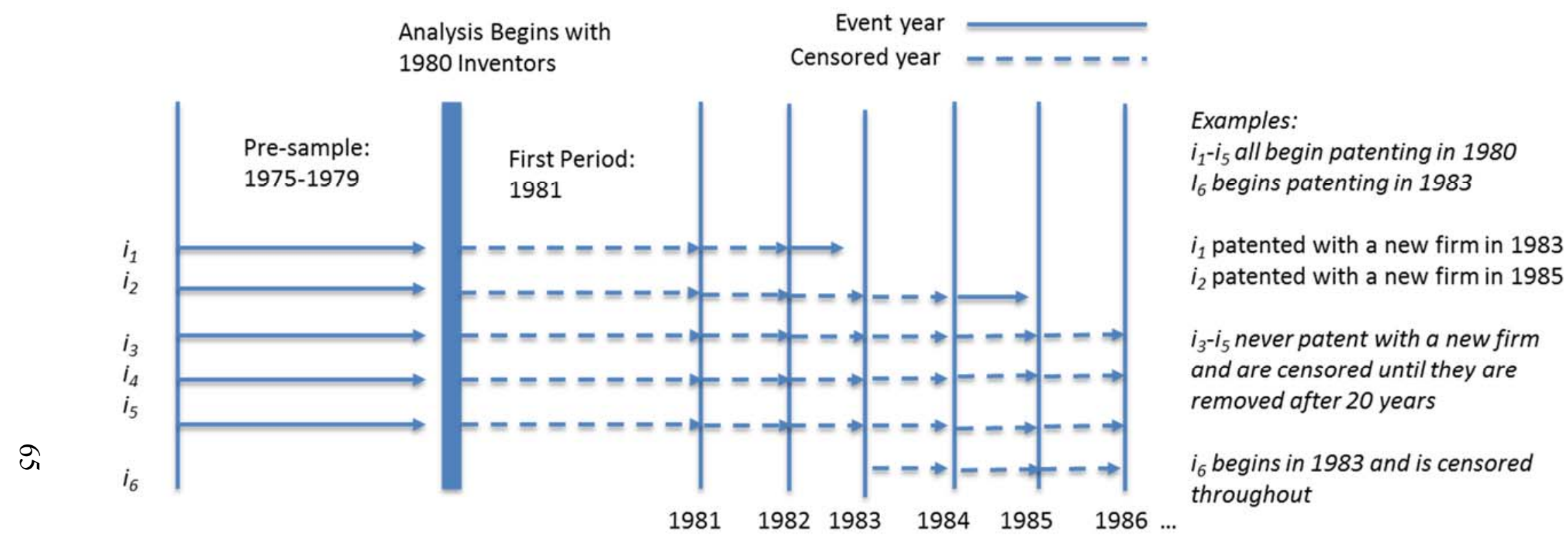

Figure 4: Example of Survival Analysis Data Structure 


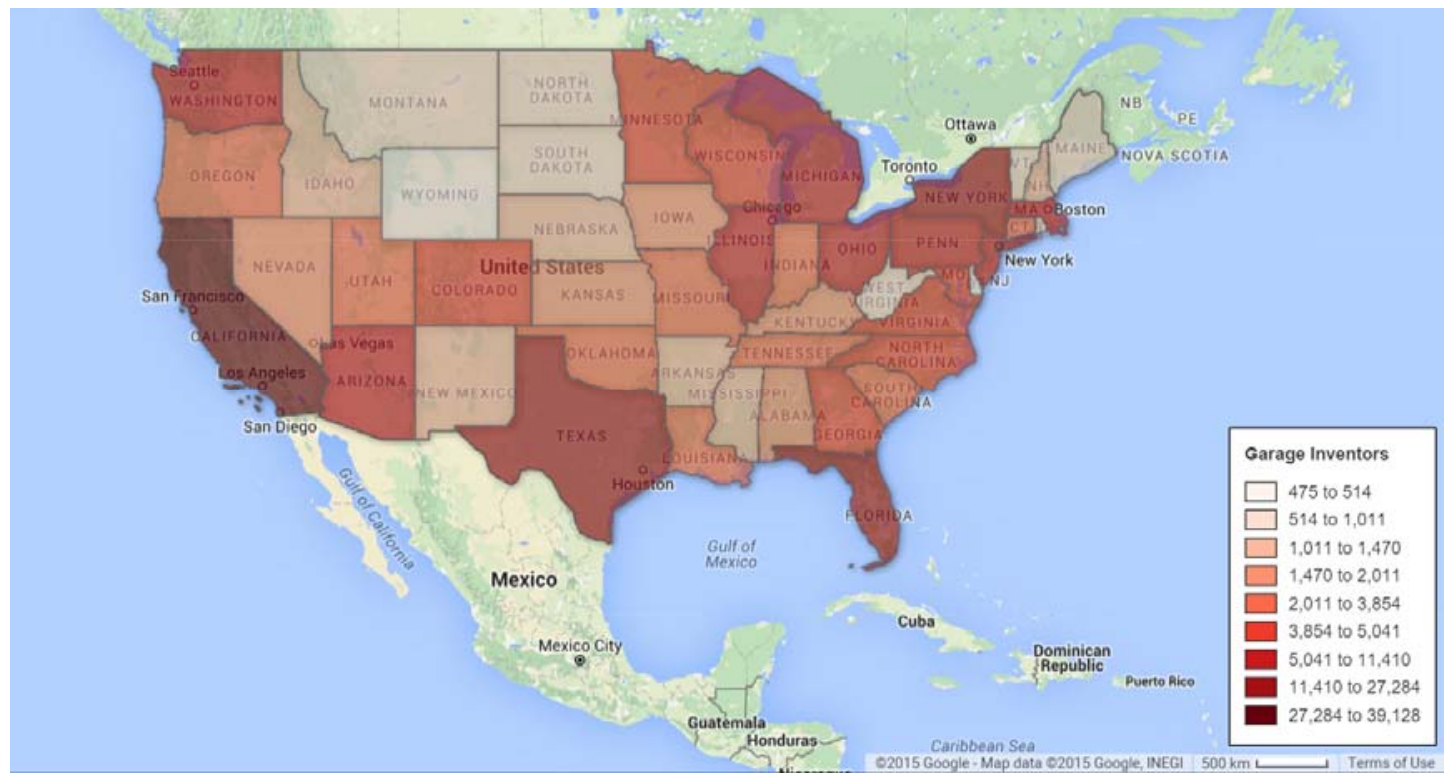

Figure 5: Garage Inventors by State

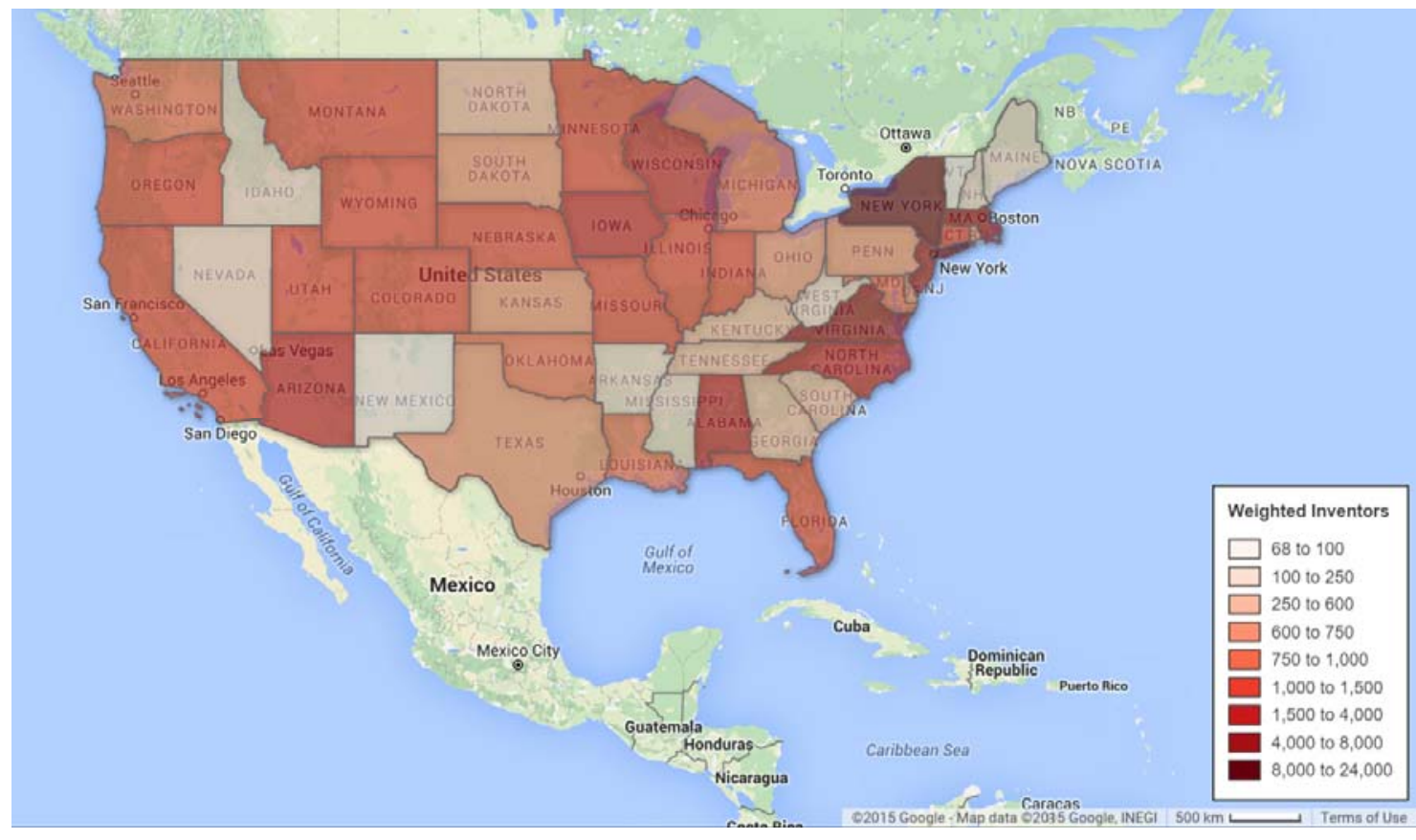

Figure 6: Garage Inventors Weighted by State Population (per million) 


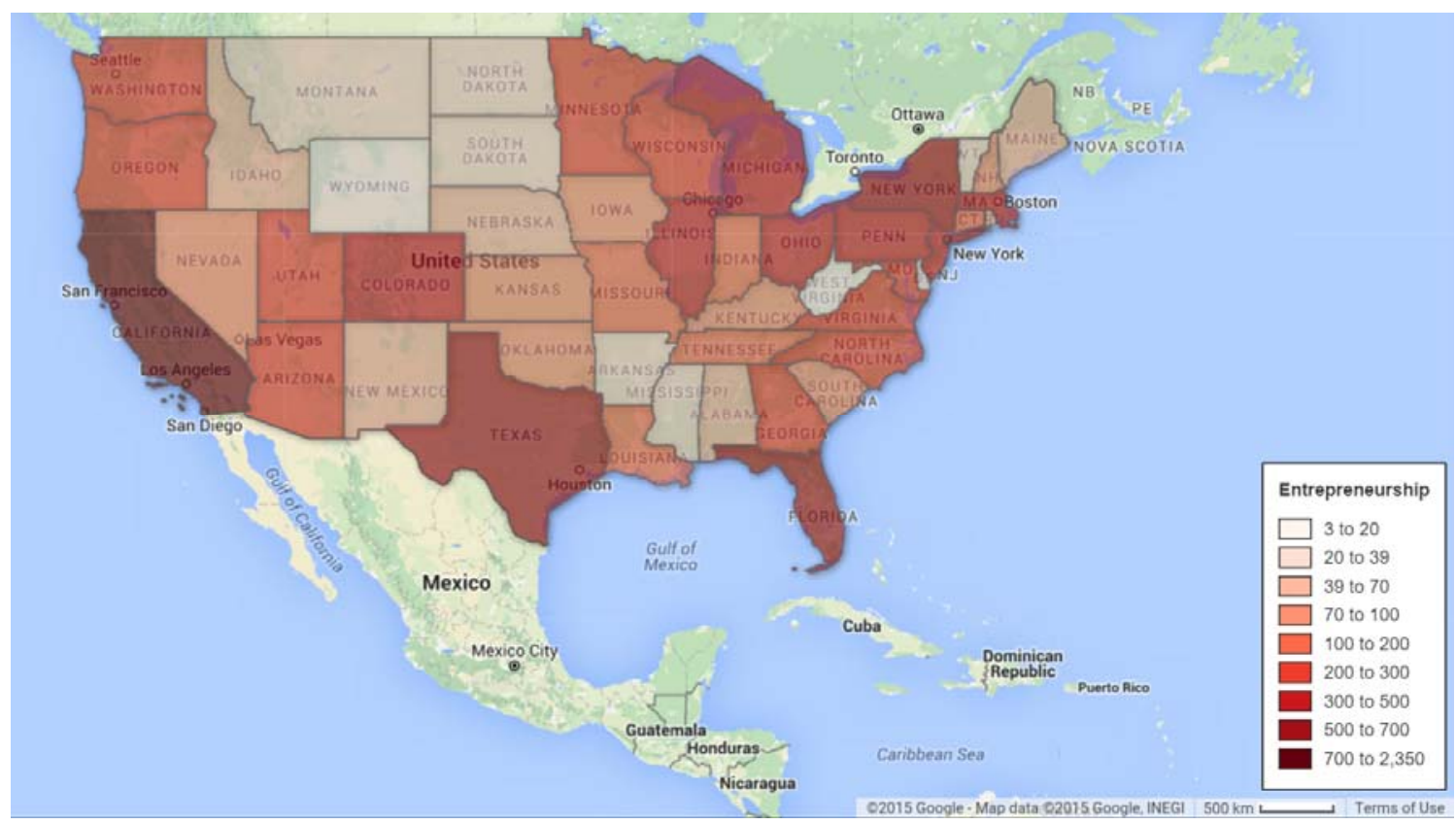

Figure 7: Garage Entrepreneurs by State

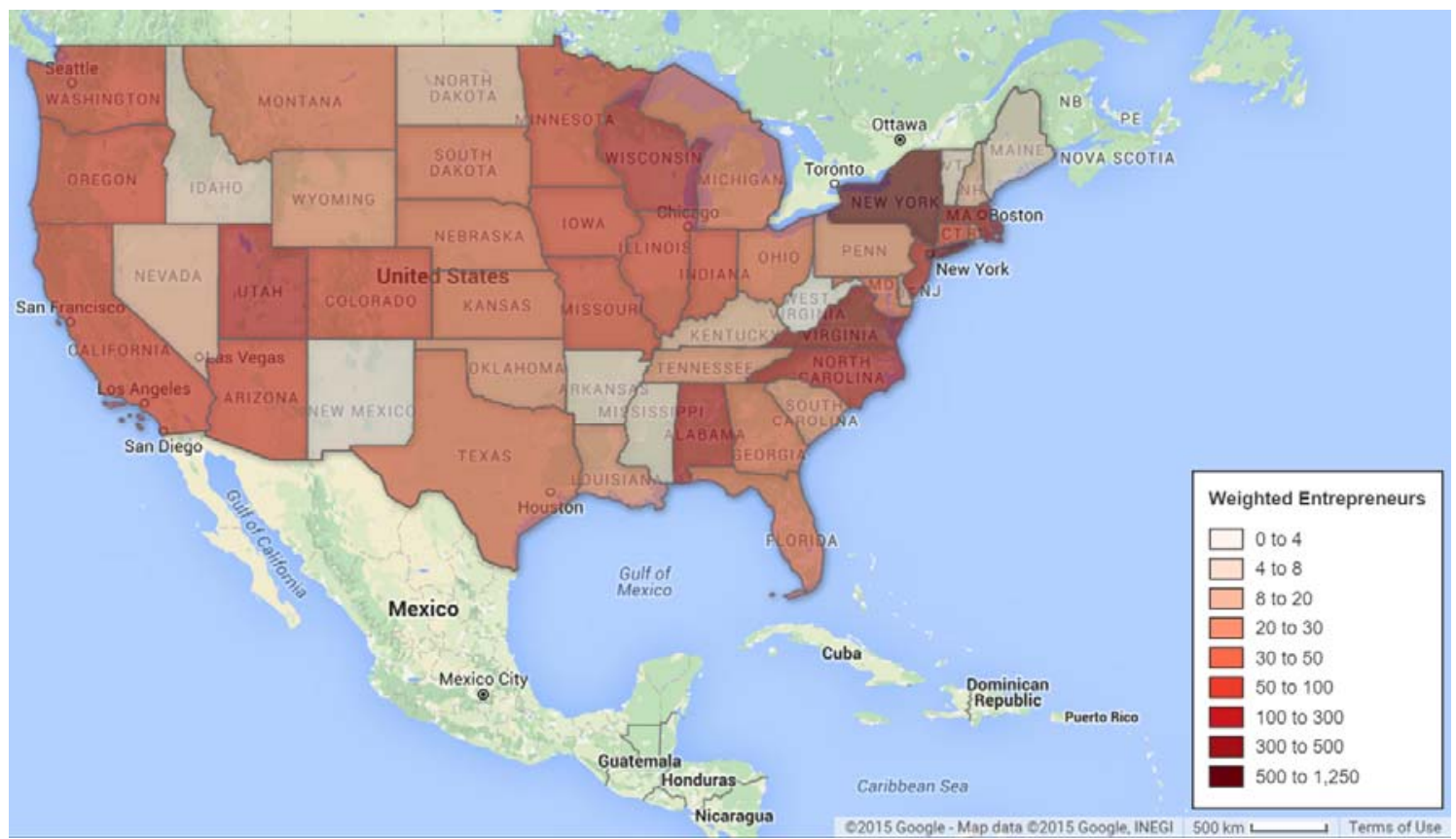

Figure 8: Garage Entrepreneurs Weighted by State Population (per million) 


\section{APPENDIX: COMPANY VERIFICATION}

\section{Identification}

This section details a process verification of the new firms identified within the patent database. The data identification for this study relies on two definitions:

1) Initial patenting career of an inventor as an independent inventor without prior organizational affiliation.

2) Starting of a new company identified as a new patenting organization within the USPTO database.

The theoretical model for this dissertation does not necessarily hinge on absolutely no prior organizational experience but does want to disconnect the knowledge creation, or the "aha moment," for the first invention from a model of clear knowledge spillover from previous technical positions. The empirical definition was chosen to limit that link to prior jobs that may have provided more direct inspiration than my model allows. Additionally, if the inventor has a direct employment contract, the garage technology should be assigned to the established organization. This could be more disconnected if the inventor already is an entrepreneur with a company and sees no difference between assigning the garage patent to himself/herself or his/her organization, creating an identification error for my analysis. This also has a positive effect for future related study in this area by selecting those individuals who are actually entrepreneurs and owners rather than employees of other organizations.

This possible identification error is then related to the identification of number 2 also. The firm is indeed a new entity within the patenting data but the question is when did the company actually get founded? This can affect the time series analysis as to when to apply environmental conditions to the decision to become an entrepreneur. This also affects the 
theoretical model separating the invention decision from the entrepreneurship decision. I performed a manual search process in order to validate the firm identification. I randomized the list of new firms from the data but manually searched for information about them with a goal of 2-3 per year from the sample. This resulted in searching for 72 firms that I had identified as new patenting organizations during $1980-2009$. The summary by year is presented in Table 12. 
Table 12: Firm Founding Verification Table by Year

\begin{tabular}{ccccc}
\hline Year & No. Checked & Newly Founded & Pre-Founded & No Info \\
\hline 1980 & 2 & 1 & 1 & 0 \\
1981 & 1 & 0 & 1 & 0 \\
1982 & 2 & 1 & 0 & 1 \\
1983 & 2 & 2 & 0 & 0 \\
1984 & 2 & 2 & 0 & 0 \\
1985 & 2 & 1 & 0 & 1 \\
1986 & 2 & 1 & 0 & 1 \\
1987 & 3 & 1 & 1 & 1 \\
1988 & 2 & 1 & 1 & 0 \\
1989 & 2 & 1 & 1 & 0 \\
1990 & 2 & 2 & 0 & 0 \\
1991 & 3 & 1 & 1 & 1 \\
1992 & 2 & 2 & 0 & 0 \\
1993 & 3 & 1 & 1 & 1 \\
1994 & 2 & 1 & 1 & 0 \\
1995 & 3 & 1 & 0 & 2 \\
1996 & 3 & 2 & 0 & 1 \\
1997 & 3 & 1 & 1 & 1 \\
1998 & 2 & 2 & 0 & 0 \\
1999 & 2 & 1 & 0 & 1 \\
2000 & 3 & 2 & 0 & 1 \\
2001 & 2 & 2 & 0 & 0 \\
2002 & 3 & 2 & 0 & 1 \\
2003 & 2 & 2 & 0 & 0 \\
2004 & 4 & 2 & 1 & 1 \\
2005 & 4 & 2 & 1 & 1 \\
2006 & 2 & 2 & 0 & 0 \\
2007 & 2 & 2 & 0 & 0 \\
2008 & 3 & 2 & 0 & 1 \\
2009 & 2 & 2 & 0 & 0 \\
\hline
\end{tabular}

*The early years (1980-1982) represent all the "new firms" in the USPTO database given the garage inventor to garage entrepreneur definition.

The full summary of the validation is presented in Table 13. I searched for 72 firms and was able to verify information for 56 of them, or about $78 \%$. Of the 56 that I could verify, $80 \%$ 
of them were founded after the date of the inventor's garage invention. I found that the other $20 \%$ of the firms were incorporated prior to the garage invention.

Table 13: Summary of Firm Founding Verification

\begin{tabular}{lccc}
\hline \multicolumn{1}{c}{ Status } & Count of Firms & $\%$ of Known & $\%$ of All Searched \\
\hline Total Checked & 72 & & \\
Total Found & 56 & & \\
& & & \\
Total Newly Founded & 45 & $20 \%$ & $63 \%$ \\
Total Pre-Founded & 11 & & $15 \%$ \\
Total No Info & 16 & $22 \%$ \\
\hline
\end{tabular}

I now detail examples of the verification process.

\section{Example Search Process and Vignettes}

To verify the information on firm foundings, I researched each firm and the known inventor through Google to collect information. This started with a survival and success bias for the firms that still had websites or had founder stories available. The next few firms all represent different categories of garage inventors and entrepreneurs that were originally in the data and information could be found.

\section{Paice, LLC}

Alex Severinsky founded Paice, LLC to commercialize patents he developed concerning hybrid vehicle technology. Severinsky held a PhD in Electrical Engineering and was working as an instructor at the University of Maryland's engineering school. He developed patent 5,343,970 for a "Hybrid electric vehicle" and filed for a patent on September 21, 1992, which was granted on September 6, 1994 (Severinsky, 1994). This patent was assigned to him alone. Recognizing the potential value, he applied for and was admitted into the University of Maryland's business incubator program. According to the Paice website history, Dr. Severinsky's interest in finding a solution to car efficiency 
problems was aroused while waiting in line for gas in the late 1970's (Alex Severinsky | Hybrid Technologist | Paice Hybrid LLC, 2013). Following this, he founded Paice, LLC and subsequently developed more patents related to hybrid vehicles including:

- Patent 6,209,672 refining the "hybrid vehicle" design on September 9, 1999 and is assigned to Paice. (Severinsky, 2001)

- Patent for "Engine start and shutdown control in hybrid vehicles" on September 10, 1999 that is co-invented and assigned to Paice (Severinsky and Louckes, 2011).

These patents are significant in defining the functional operating range for hybrid vehicle connections. The American Society of Mechanical Engineers has recognized Dr. Severinsky's technical accomplishments as significant by awarding him the Thomas A. Edison Patent Award for technologies of importance for breakthroughs or that lead to valuable companies.

A patent attorney firm performed an analysis of the hybrid industry and concluded that Paice held four of the top nine most dominant patents by citations (Lloyd and Blows, 2009). Paice has won lawsuits for patent infringement against Ford and Toyota resulting in a forced licensing fee for their hybrid car sales. Paice has open lawsuits against Kia and Hyundai. (Paice, LLC, 2010).

However, this was not his first venture. Dr. Severinsky had previously founded Viteq which developed uninterrupted power supplies for computers. He developed 14 patents between 1987 (Severinsky, 1989) and 1991 (Severinsky, 1989) for Viteq before he sold the business. While this company fits the pattern of independent invention turned new firm, due 
to his prior patenting relationship, Dr. Severinsky and Paice is removed from the strict identification analysis for this study but offers more opportunity for future study.

Lastly, Dr. Severinsky stepped down as the CEO of Paice in 2006 and founded a new company, Fuelcor.

\section{Denecke, Inc.}

Denecke, Inc. makes electronic time code slates for the movie and entertainment businesses. A time code slate is the "clapper" used by directors at the beginning of shots. The founder, Mike Denecke, was working on film sets at the time as a sound and electronic designer. The owner of another firm, Ivan Kruglak from Coherent Communications, introduced Mike to one of the first electronic time slates in 1985. Mike recognized the value of syncing multiple shots electronically but the product was not taking off (Denecke, 1997b). Under his legal name, Henry M. Denecke applied for a patent for a "Time Code Decoder" on May 24, 1985, which would result in patent 4,646,167 granted on February 24, 1987 (Denecke, 1987). Mike Denecke is the owner of this patent. Before this, Mike Denecke was also the inventor of two patents:

- $\quad$ Patent 4,227,126 applied for on February 21, 1978 for a "Shaft rotation interlock system for film editing tables and the like" (Denecke, 1980).

- $\quad$ Patent 4,328,484 applied for on September 2, 1980 for a "Method and apparatus for numerically converting a parallel binary coded number from a first unit system to a second unit system (Denecke, 1982).

Following these non-assigned patents, Mike filed for a patent for a "Battery Holder", numbered 5,601,940 on May 11, 1995 under the company name "Denecke, Inc." (Denecke, 
1997a). The Denecke time code slates are the "industry standard" according to their website (Denecke, 1997b).

Denecke, Inc. was actually founded in 1975 by Mike Denecke as a personal venture. He diversified into the technology market as he saw a demand and could develop the product (Denecke, 1997b). Due to this reason, he qualifies under the initial patent-level identification strategy but would be removed upon full company verification.

\section{Braintexter Inc.}

Founded by Riccardo and Flavio Vieri, Braintexter Inc. holds patents regarding short message service (SMS) texting. Specifically, they independently developed a patent to convert SMS text to speech (Vieri, Tomasso, and Vieri, 2007) in 2003. Subsequently, they developed a method for applying contextual advertising based on the sender, receiver, and content of text messages in 2009 (Vieri, 2009) and 2013 (Vieri, 2013). The text-to-speech patent was independently owned but the advertising patents were subsequently assigned to their new firm, Braintexter Inc (Braintexter Inc: About Us, 2010). In 2008, Braintexter, Inc., was incorporated in Delaware (Bizapedia, 2014) and Riccardo and Flavio Vieri reassigned their older patents to the firm. In 2011, Braintexter's patents were sold and reassigned to Apple (Vieri et al., 2007).

\section{Dietrick Sports Products}

Donald E. Cech developed patent 5,630,652 for a "releasable axle assembly for skate wheels" (Cech, 1997) in 1995 and created the company Dietrick Sports Products, Inc. Prior to this, Donald Cech has developed two previous patents related to skating - Patent 5,226,673 for a "Braking Assembly and Method" in 1991 (Cech, 1993) and Patent 5,351,974 for "In-line skate braking assembly and method" in 1992 (Cech, 1994). 

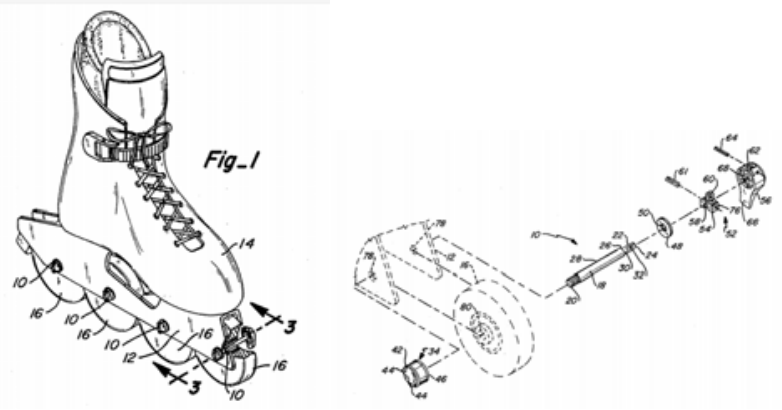

Figure 9: Donald Cech's Invention of "Releasable Axle Assembly for Skate Wheels"

Living in Colorado, he assigned this patent to a new firm, Dietrick Sports Products, Inc. in Steamboat Springs, Colorado (Cech, 1997).

\section{Stamps.com, Inc.}

Mohan Ananda is the founding CEO of Stamps.com, which is highlighted by his public LinkedIn profile in Figure 10. He has three independent patents and starts his patenting career as a garage inventor within the newly developed "Business Method Patents" class 705 in the USPTO classification system. All of his original three patents start with the title "Secure software rental system using... (Ananda, 1996a, 1996b, 1997)." His fourth patent, 6,671,813 (Ananda, 2003), is filed under Stamps.com, which does cite one of his earlier patents. It is the first patent by that organization. This patent is for "Secure on-line PC postage metering system." He then has four more patents under the organization Stamps.com. By the time he has his fifth organizational patent, it is actually the $27^{\text {th }}$ patent for Stamps.com overall. He ends with two more independent patents to end his patenting career within this data, for a total of 10 patents. 


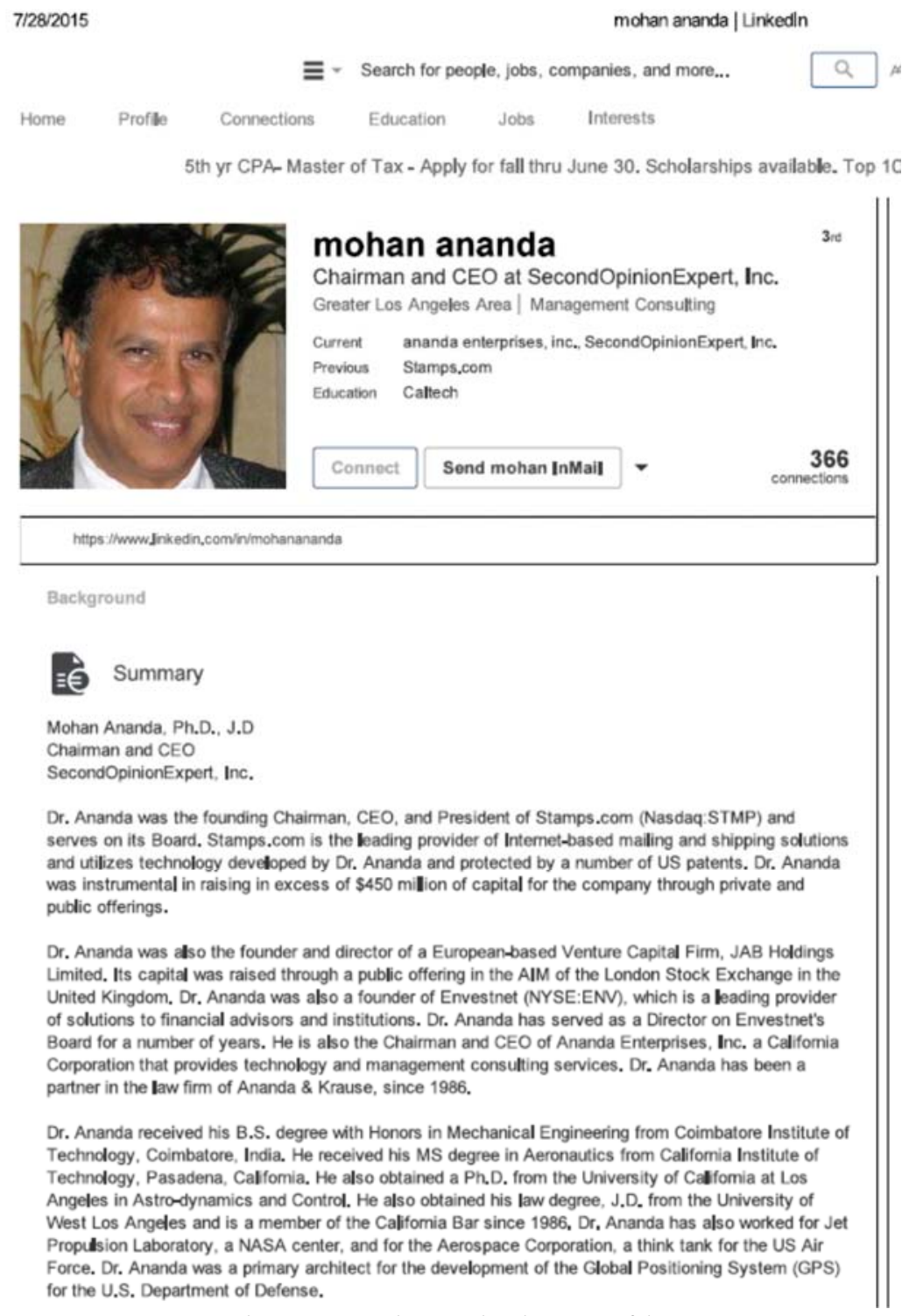

Figure 10: Mohan Ananda LinkedIn Profile - Stamps.com

\section{Metcast Associates}

The next series of organizations have better founding information. Figure 11 is a cut-out of

the patent page for Daniel Groteke's first patent. Mr. Groteke lives on 1228 Ridge Cliff Rd., Cincinnati, Ohio and files for what will become patent 4,394,271 on April 23, 1981 for an

“Apparatus and Method for Filtration of Molten Metal” (Groteke, 1983). 


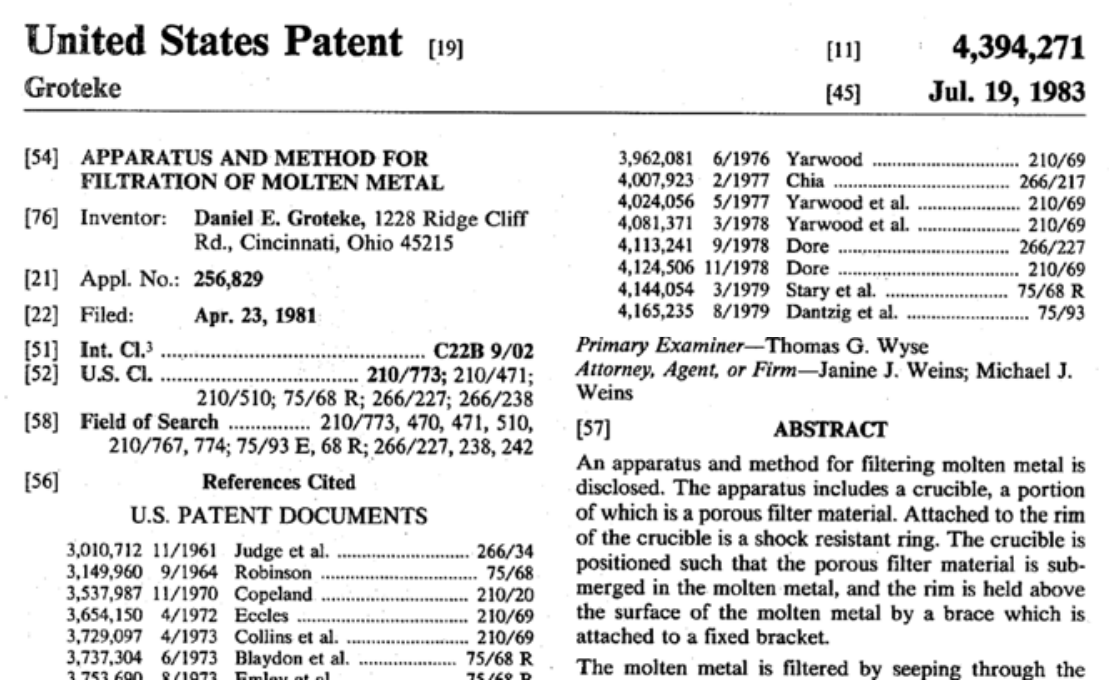

Figure 11: Daniel Groteke Garage Patent

On April 20, 1984, he and Avery Kearney, living in Cincinnati, Ohio and Valparaiso, Indiana respectively, jointly file for a patent for "Molten Metal Transfer Crucible with External

Filter" (Groteke and Kearney, 1986). In Figure 12, I can see that this patent is assigned to Metcast Associates, based in Cincinnati, Ohio.

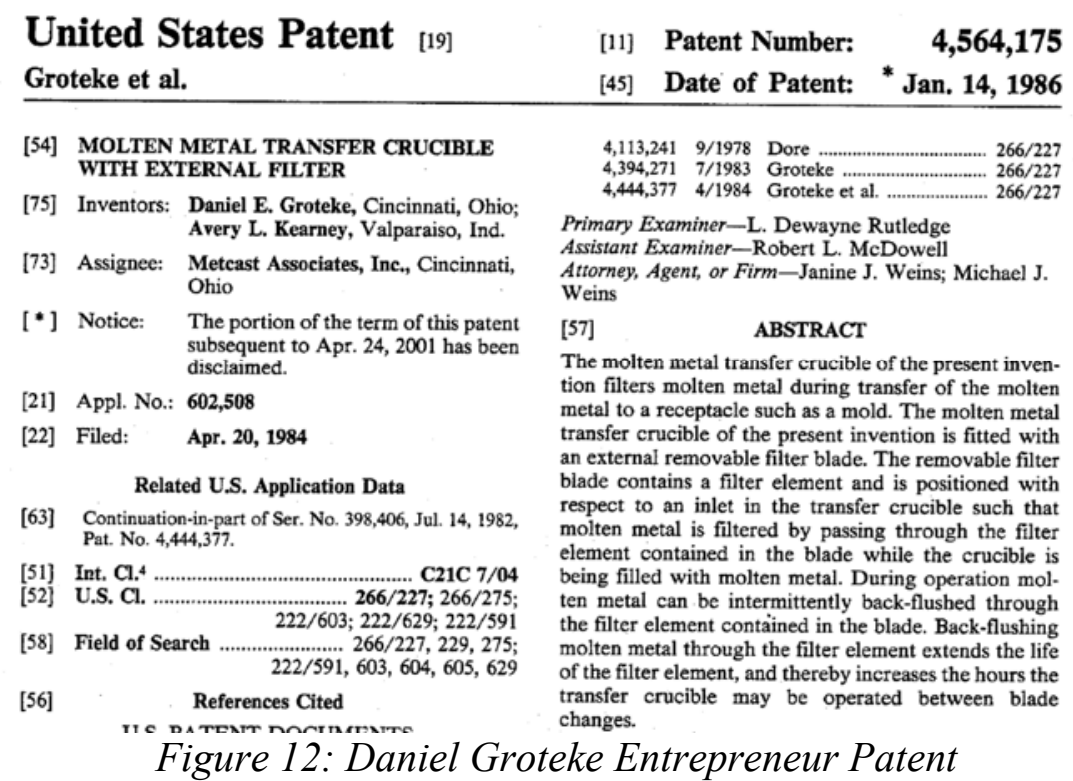


Next, website Bizapedia.com provides a resource for searching business names and individuals involved in incorporating businesses across the United States. Figure 13 demonstrates one such result. From this search, it is clear that Metcast Associates was founded on June 24, 1976, registered in Ohio, and owned by one principal - Daniel E. Groteke (Bizapedia, 2016). The information is in line with the patenting behavior but demonstrates that the entity was founded prior to the garage invention patent that had been personally assigned by the inventor.

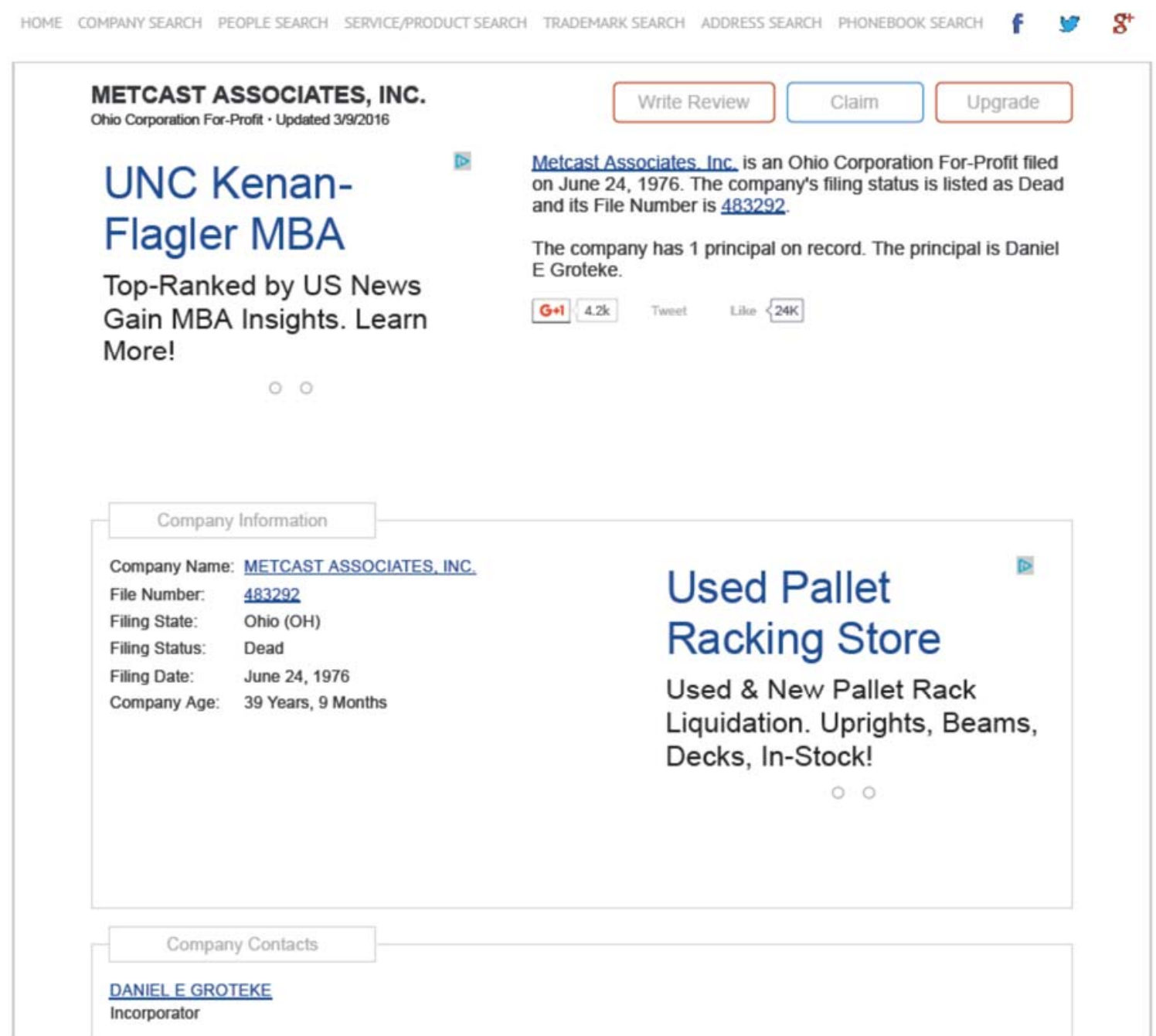

Figure 13: Example Search Result Showing Metcast Associates Founding Date 


\section{Sixty Technologies, LLC}

Another test with Bizapedia verification comes from Albert E. Johnstone. He and Frank Ratliff develops a patent 7,107,725 in 2001 for "Swivel joint apparatus and method for utility supply to a rotatable building," originally assigned to Albert and Janet Johnstone. By the time the patent is granted in September 2006, Johnstone assigns it to the new company, 3sixty Technologies (Johnstone III and Ratliff, 2006). On May 31, 2006, he, Frank Ratliff, David A. Berg, and Michael L. Rogers file for the first patent to be originally assigned to this new company also (Ratliff et al., 2009). From the Bizapedia results in Figure 14, I can see that 3Sixty Technologies, LLC was founded on May 25, 2006 by Al Johnstone, living in La Mesa, California, and David A. Berg living in Henderson, NV (Bizapedia, 2015). Albert Johnstone was the hobbyist and visionary for rotating buildings, designing the technology and the building himself. David Berg saw a news article about the Johnstone family house, the first test of the technology, and partnered with Johnstone and his colleagues between 2004 and 2006 to form the new 3Sixty Technologies as its CEO. 
3SIXTY TECHNOLOGIES, LLC Nevada Secretary or State Bushess Registration - Updated 5/18/2015

Write Review

Claim

Upgrade

\section{Local IT Solutions}

Complete IT Services for

Businesses Servers,

Routers, Network Admin

$\circ \circ$

3 sixty Technologies, UC is a Nevada Domestic Limited-Liability Company filed on May 25, 2006. The company's filing status is listed as Active and its File Number is E0409942006-5.

The Registered Agent on file for this company is David A Berg and is located at 2654 W Horizon Ridge Pkwy B5-128, Henderson, NV 89052.

The company has 2 principals on record. The principals are AI Johnstone from La Mesa CA and David A Berg from Henderson NV.

$0+142 \mathrm{~K}$ Tweet Lito $20 \mathrm{~K}$

Company Information

Company Name: 3 SIXTYY TECHNOLOGIES, LLC

File Number: E0409942006-5

Filing State: Nevada (NV)

Filing Status: Active

Filing Date: May 25, 2006

Company Age: $\quad 9$ Years, 10 Months

Registered Agent. David A Berg

2054 W Honizen Ridge Plwn B5-128 Henderson. NV 89052

Report Due Date: May 31, 2015

Better Video Conferencing

Superior Conferencing for Business. Fast, Secure \& Easy. Try Free Demo!

$\circ 0$

Company Contacts

AL.JHNSTONE

Manager

- 4903 Mt. Helix Drive

$\triangle$ La Mesa, CA 91941

View Phone Book Listings For Al Johnstone In Calfomia

DAVID A BERG

Manager

C. 2854 W. Horizon Ridoe Pkwy B5-128

CHenderson. NV 89052

View Nationwide Phone Book Listings For David Berg

Figure 14: Example Founding Information for 3sixty Technologies, LLC 
Innovative Sports, Inc.

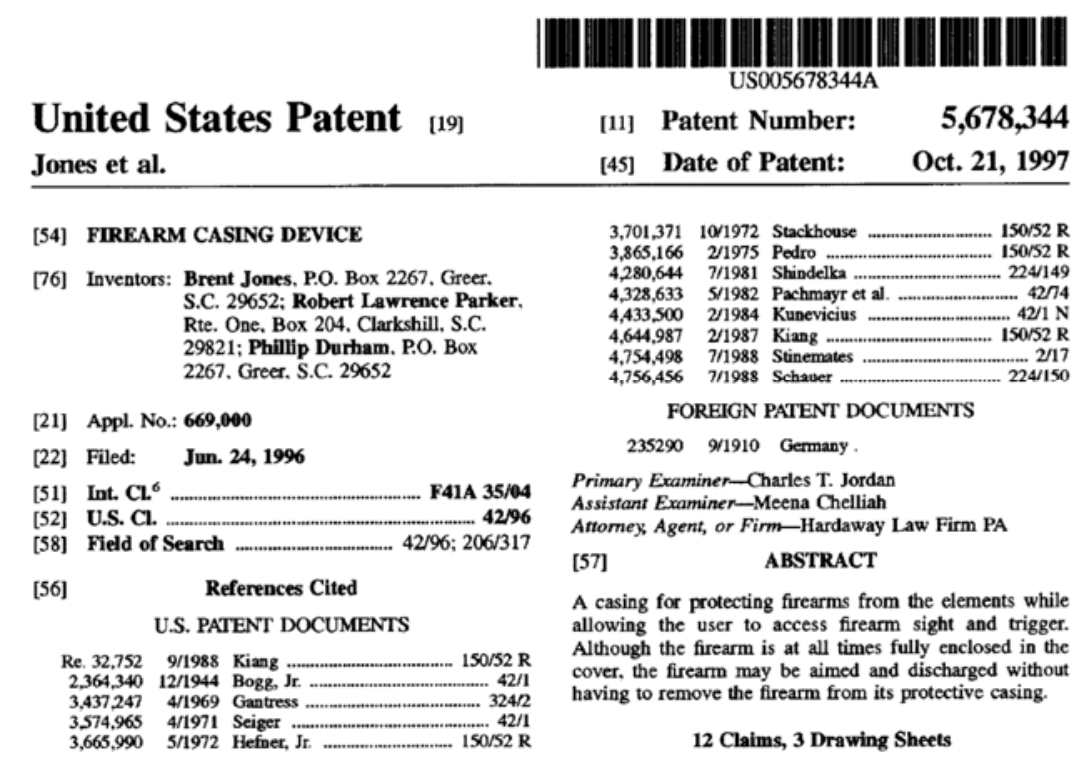

Figure 15: Brent Jones Garage Patent 5, 678,344

Innovative Sports, Inc. is a company that appears in the patent database for the first time on a patent filed for in 1998. Brent Jones had an original patent, viewed in Figure 15, for

"Firearm Casing Device" with colleagues in 1996, granted in 1997, which is assigned to three co-inventors (Jones, Parker, and Durham, 1997).

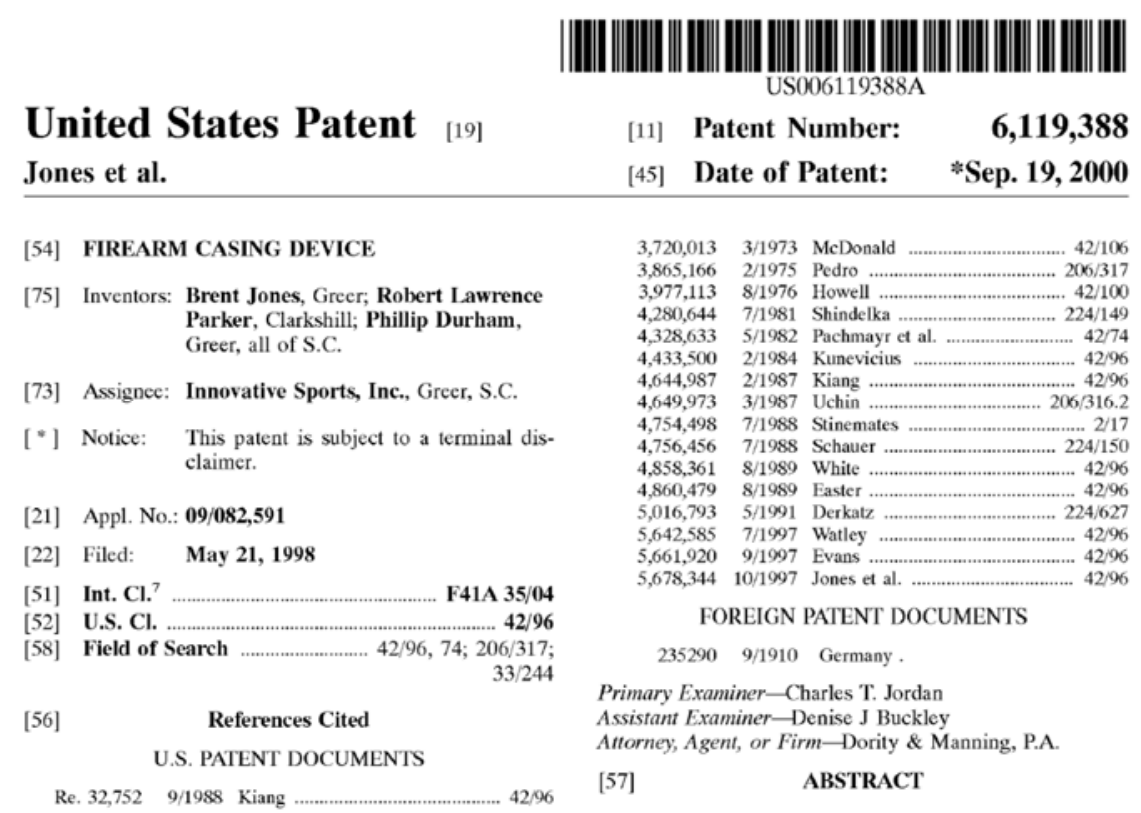

Figure 16: Innovative Sports Garage Entrepreneurial Patent 6,119,388 
In 1998, they follow up with patent 6,119,388 (Jones, Parker, and Durham, 2000), further

improving the line of firearm casing device, and assigned to their new company, Innovative

Sports, Inc. This patent was filed on May 21, 1998 and granted on September 19, 2000.

Through detailed search, a news article from the Spartanburg Herald Journal, presented in

Figure 17, highlights their founding in 1997 and early business details (Orr, 1999), which is

after the trio's first patent and before their second application.

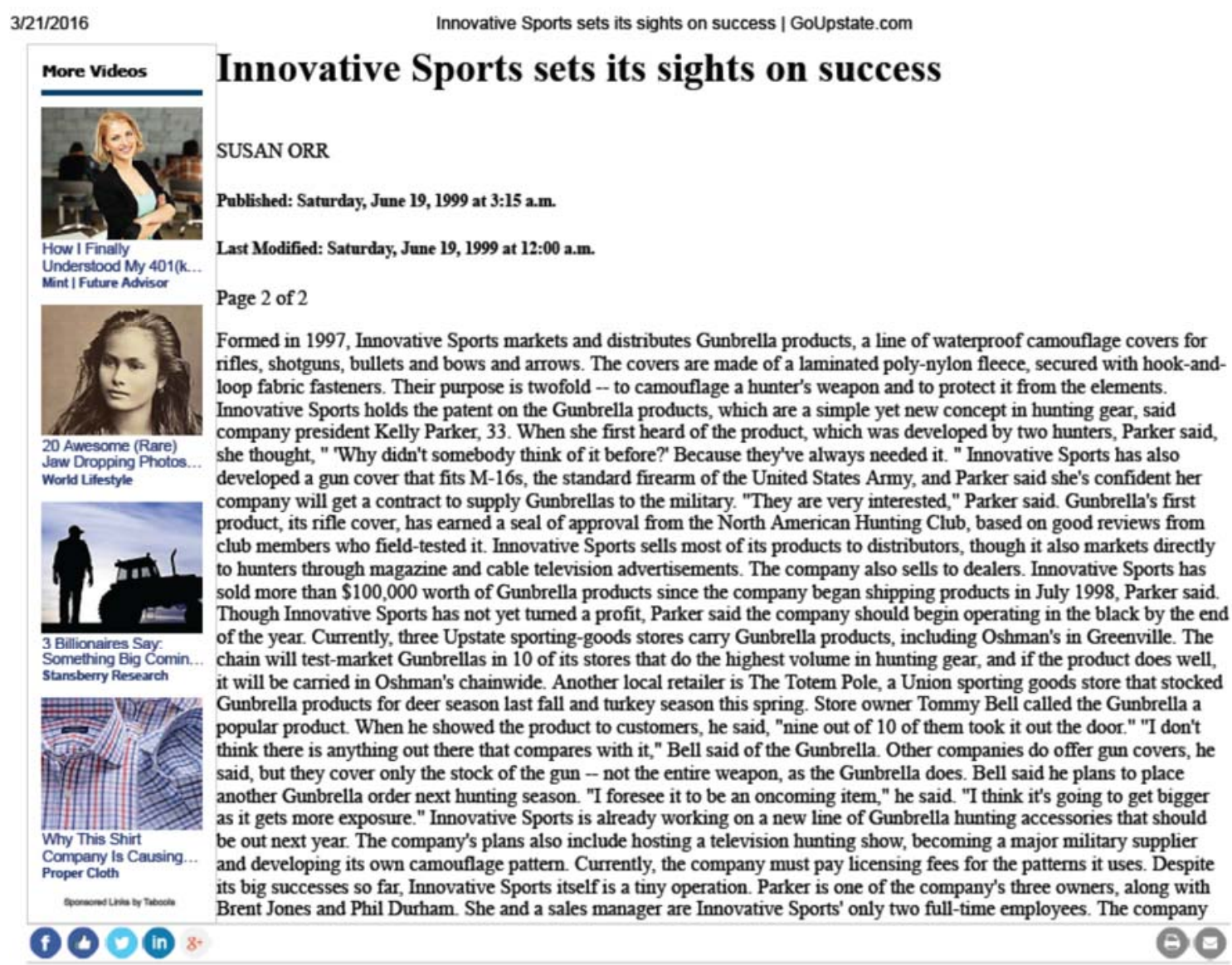

Figure 17: News Search Results Detailing Innovative Sports’ Founding year 


\section{Example Technologies Never Associated with New Firms}

For reference, Table 14 provides a random list of technologies and inventors who were never associated with a firm beyond the development of the focal independent technology. This allows insight into the control group that was at risk of firm formation but never proceeded beyond the independent technological development.

Table 14: Example Technologies and Inventors Never Associated with a New Firm

\begin{tabular}{|c|c|c|c|c|c|}
\hline \# & Patent & First Name & Last Name & $\begin{array}{l}\text { Application } \\
\text { Date }\end{array}$ & Technology \\
\hline 1 & 4317653 & MARTHA S & WAHL & $1 / 21 / 1980$ & Educational blocks \\
\hline 2 & 4340364 & MILTON G & DEEMER & $8 / 18 / 1980$ & Endodontic test file \\
\hline 3 & 4468721 & STEVEN & VANDRILLA & $5 / 11 / 1983$ & $\begin{array}{l}\text { Candle assemblies employing a } \\
\text { window sill locking leash }\end{array}$ \\
\hline 4 & 4513573 & HARALD F & FUNK & 9/9/1983 & $\begin{array}{l}\text { System for treating and } \\
\text { recovering energy from exhaust } \\
\text { gases }\end{array}$ \\
\hline 5 & 4541547 & RONALD J & MIKNYOCKI & $10 / 21 / 1983$ & Token or card dispenser \\
\hline 6 & 4520431 & MICHAEL & FANELLI & $6 / 11 / 1984$ & Collapsible Lantern \\
\hline 7 & 4592483 & RAYMOND E & SCOUTEN & $8 / 6 / 1984$ & $\begin{array}{l}\text { Container and separate co- } \\
\text { operating lid }\end{array}$ \\
\hline 8 & 4668250 & JAN T & DRESE & $6 / 14 / 1985$ & $\begin{array}{l}\text { Process for continuously } \\
\text { removing and recovering } \\
\text { respectively a gas dissolved in a } \\
\text { liquid, particularly ammonia } \\
\text { from aqueous ammonia waste } \\
\text { water }\end{array}$ \\
\hline 9 & 4644683 & DARRELL R & JONES & $7 / 12 / 1985$ & $\begin{array}{l}\text { Method and apparatus for } \\
\text { enhancing the pollination of } \\
\text { alfalfa }\end{array}$ \\
\hline 10 & 4884033 & NOEL P & MCCONCHIE SR & $6 / 6 / 1988$ & $\begin{array}{l}\text { Diagnostic test apparatus for } \\
\text { electrical system of automotive } \\
\text { vehicle }\end{array}$ \\
\hline 11 & 4846443 & HARVEY C & COLLINS & $7 / 13 / 1988$ & Floor covering installation tool \\
\hline 12 & 5021424 & JENNYLYN & LAWTON WALL & $6 / 1 / 1989$ & $\begin{array}{l}\text { Vitamin composition for } \\
\text { treatment of flea infestation in } \\
\text { animals }\end{array}$ \\
\hline 13 & 4966320 & MITCHELL & BLOOM & $11 / 13 / 1989$ & $\begin{array}{l}\text { Simulated pouch with interior, } \\
\text { concealed holster }\end{array}$ \\
\hline 14 & 5125526 & ARNOLD J & SUMANIS & $11 / 21 / 1991$ & $\begin{array}{l}\text { Waste receptacle with interior } \\
\text { bag that is opened and closed } \\
\text { automatically }\end{array}$ \\
\hline 15 & 5743105 & KEIJIRO & YAMAUCHI & 9/30/1994 & $\begin{array}{l}\text { Apparatus for producing ice } \\
\text { vessel }\end{array}$ \\
\hline
\end{tabular}




\section{REFERENCES}

Agarwal R, Echambadi R, Franco AM, Sarkar MB. 2004. Knowledge Transfer Through Inheritance: Spin-Out Generation, Development, and Survival. Academy of Management Journal 47(4): 501-522.

Agarwal R, Shah SK. 2014. Knowledge sources of entrepreneurship: Firm formation by academic, user and employee innovators. Research Policy 43(7): 1109-1133.

Ahuja G, Lampert C. 2001. Entrepreneurship in the large corporation: a longitudinal study of how established firms create breakthrough inventions. Strategic Management Journal 22(67): 521-543.

Aldrich HE. 2014. The Democratization of Entrepreneurship? Hackers, Makerspaces, and Crowdfunding. Philadelphia, PA: 7.

Aldrich HE, Ruef M. 2006. Organizations Evolving, 2nd ed. Sage Publications Ltd: London, UK.

Alex Severinsky | Hybrid Technologist | Paice Hybrid LLC. 2013. Paice. Available at: http://www.paicehybrid.com/about/alex-severinsky/ [1 April 2014].

Allison P. 1995. Survival analysis using SAS : a practical guide. SAS Institute: Cary, NC.

Alvarez SA, Busenitz LW. 2001. The Entrepreneurship of Resource-Based Theory. Journal of Management 27(6): 755-775.

Amesse F, Desranleau C, Etemad H, Fortier Y, Seguin-Dulude L. 1991. The individual inventor and the role of entrepreneurship : A survey of the Canadian evidence. Research Policy 20(1): 13-27.

Amit R, Glosten L, Muller E. 1993. Challenges to Theory Development in Entrepreneurship Research. Journal of Management Studies 30(5): 815-834.

Ananda M. 1996a, February 27. Secure software rental system using continuous asynchronous password verification. Available at:

http://www.google.com/patents/US5495411.

Ananda M. 1996b, August 20. Secure software rental system using distributed software. Available at: http://www.google.com/patents/US5548645.

Ananda M. 1997, June 10. Secure software rental system using continuous asynchronous password verification. Available at: http://www.google.com/patents/US5638513.

Ananda M. 2003, December 30. Secure on-line PC postage metering system. Available at: http://www.google.com/patents/US6671813. 
Arora A, Cohen WM, Walsh JP. 2014. The Acquisition and Commercialization of Invention in American Manufacturing: Incidence and Impact. Working Paper, National Bureau of Economic Research. Available at: http://www.nber.org/papers/w20264.

Åstebro TB. 1998. Basic Statistics on the Success Rate and Profits for Independent Inventors. Entrepreneurship: Theory \& Practice 23(2): 41-48.

Åstebro TB. 2003. The Return to Independent Invention. The Economic Journal 113(484): 226-239.

Åstebro TB. 2004. Key success factors for technological entrepreneurs' R D projects. IEEE Transactions on Engineering Management 51(3): 314-321.

Åstebro TB, Dahlin KB. 2005. Opportunity knocks. Research Policy 34(9): 1404-1418.

Åstebro TB, Gerchak Y. 2001. Profitable Advice: the Value of Information Provided by Canada's Inventor's Assistance Program. Economics of Innovation and New Technology 10(1): 45-72.

Åstebro TB, Michela JL. 2005. Predictors of the Survival of Innovations. Journal of Product Innovation Management 22(4): 322-335.

Audia PG, Rider CI. 2005. A Garage and an Idea: What more does an Entrepreneur Need? California Management Review 48(1): 6-28.

AutoMoby. 2013, November 26. The All New 2014 Cadillac CTS Sedan - Garages (TV Commercial). Available at:

http://www.youtube.com/watch?v=flThllGVZEw\&feature=youtube gdata_player [2 April 2014].

Bettis RA, Ethiraj S, Gambardella A, Helfat C, Mitchell W. 2016. Creating repeatable cumulative knowledge in strategic management. Strategic Management Journal 37(2): 257261.

Bhide A. 1992. Bootstrap Finance: The Art of Start-ups. Harvard Business Review 70(6): 109-117.

Bizapedia. 2014, April 17. Braintexter, Inc. in Wilmington, DE - Reviews - Bizapedia Profile. Bizapedia.com. Available at: http://www.bizapedia.com/de/BRAINTEXTERINC.html [25 March 2016].

Bizapedia. 2015, May 18. 3sixty Technologies, LLC in Henderson, NV - Reviews Bizapedia Profile. Bizapedia.com. Available at: http://www.bizapedia.com/nv/3SIXTYTECHNOLOGIES-LLC.html [28 March 2016].

Braintexter Inc: About Us. 2010. Available at: http://brilliant-patents.com/ [2 April 2014]. 
Carnahan S. 2013. Employee Departure from Organizations: Three Empirical Essays. Ph.D., University of Maryland, College Park. Available at:

http://drum.lib.umd.edu//handle/1903/14291.

Cech DE. 1993, July 13. Braking assembly and method. Available at:

http://www.google.com/patents/US5226673.

Cech DE. 1994, October 4. In-line skate braking assembly and method. Available at: http://www.google.com/patents/US5351974.

Cech DE. 1997, May 20. Releasable axle assembly for skate wheels. Available at: http://www.google.com/patents/US5630652.

Chatterji AK. 2009. Spawned with a silver spoon? Entrepreneurial performance and innovation in the medical device industry. Strategic Management Journal 30(2): 185-206.

Chatterji AK, Fabrizio K. 2012. How Do Product Users Influence Corporate Invention? Organization Science 23(4): 971-987.

Chatterji AK, Fabrizio KR. 2014. Using users: When does external knowledge enhance corporate product innovation? Strategic Management Journal 35(10): 1427-1445.

Cheyre C, Klepper S, Veloso F. 2015. Spinoffs and the Mobility of U.S. Merchant Semiconductor Inventors. Management Science 61(3): 487-506.

Christensen CM. 1997. The Innovator's Dilemma: When New Technologies Cause Great Firms to Fail. Harvard Business School Press: Cambridge, MA.

Christensen CM, Bower JL. 1996. Customer Power, Strategic Investment, and the Failure of Leading Firms. Strategic Management Journal 17(3): 197-218.

Cohen J. 2011, October 6. Great American Garage Entrepreneurs. History.com. Available at: http://www.history.com/news/great-american-garage-entrepreneurs [27 February 2014].

Cohen WM. 2010. Chapter 4 - Fifty Years of Empirical Studies of Innovative Activity and Performance. In Handbook of the Economics of Innovation, Vol. 1, Hall BH, Rosenberg N (eds). North-Holland: Boston, Volume 1: 129-213.

Cohen WM, Klepper S. 1992. The tradeoff between firm size and diversity in the pursuit of technological progress. Small Business Economics 4(1): 1-14.

Cohen WM, Klepper S. 1996a. Firm Size and the Nature of Innovation within Industries: The Case of Process and Product R\&D. The Review of Economics and Statistics 78(2): 232-243.

Cohen WM, Klepper S. 1996b. A Reprise of Size and R \& D. The Economic Journal 106(437): 925-951. 
Cohen WM, Levin RC. 1989. Empirical Studies of Innovation and Market Structure. In Handbook of Industrial Organization, Schmalensee R, Willig RD (eds). North-Holland: New York: Ch. 18 - 1059-1107.

Dahlin K, Taylor M, Fichman M. 2004. Today's Edisons or weekend hobbyists: technical merit and success of inventions by independent inventors. Research Policy 33(8): 11671183.

Delmar F, Davidsson P. 2000. Where do they come from? Prevalence and characteristics of nascent entrepreneurs. Entrepreneurship \& Regional Development 12(1): 1-23.

Denecke HM. 1980, October 7. Shaft rotation interlock system for film editing tables and the like. Available at: https://www.google.com/patents/US4227126.

Denecke HM. 1982, May 4. Method and apparatus for numerically converting a parallel binary coded number from a first unit system to a second unit system.

Denecke HM. 1987, February 24. Time code decoder. Available at: www.google.com/patents/US4646167.

Denecke HM. 1997a, February 11. Battery holder. Available at: www.google.com/patents/US5601940.

Denecke M. 1997b. The Beginning of Time: Why Denecke Got into the Slate Business. Available at: http://www.denecke.com/About\%20Us/aboutus.html.

Ecclestone C. 2014, January 4. Ad Break: The 2014 Cadillac CTS Came From An American Garage. GM Authority. Available at: http://gmauthority.com/blog/2014/01/ad-break-the2014-cadillac-cts-came-from-an-american-garage/.

Elfenbein DW, Hamilton BH, Zenger TR. 2010. The Small Firm Effect and the Entrepreneurial Spawning of Scientists and Engineers. Management Science 56(4): 659-681.

Engber D. 2013, May 27. FYI: When Did People Start Inventing Things In The Garage? Popular Science. Available at: http://www.popsci.com/technology/article/2013-04/fyi-whendid-people-start-inventing-things-garage [27 February 2014].

Fauchart E, Gruber M. 2011. Darwinians, Communitarians, and Missionaries: The Role of Founder Identity in Entrepreneurship. Academy of Management Journal 54(5): 935-957.

Fleming L. 2001. Recombinant Uncertainty in Technological Search. Management Science 47(1): 117-132.

Fleming L. 2007. Breakthroughs and the 'Long Tail' of Innovation. MIT Sloan Management Review. Available at: http://sloanreview.mit.edu/article/breakthroughs-and-the-long-tail-ofinnovation/. 
Fontana R, Nuvolari A, Shimizu H, Vezzulli A. 2012. Schumpeterian patterns of innovation and the sources of breakthrough inventions: evidence from a data-set of R\&D awards.

Journal of Evolutionary Economics 22(4): 785-810.

Foray D, Lissoni F. 2010. Chapter 6 - University Research and Public-Private Interaction. In Handbook of the Economics of Innovation, Vol. 1, Hall BH, Rosenberg N (eds). NorthHolland, Volume 1: 275-314. Available at:

http://www.sciencedirect.com/science/article/pii/S0169721810010063.

Franklin B, Taylor JS. 2015, March. Yearbook 2015: National Venture Capital Association Stats \& Studies. NVCA. Available at: http://nvca.org/research/stats-studies/ [30 September 2015].

Freeman J. 1986. Entrepreneurs as organizational products: semiconductor firms and venture capital firms. Advanced Studies in Entrepreneurship, Innovation, and Economic Growth 1: $33-52$.

Gans JS, Hsu DH, Stern S. 2002. When Does Start-Up Innovation Spur the Gale of Creative Destruction? The RAND Journal of Economics 33(4): 571-586.

Gans JS, Stern S. 2003. The product market and the market for 'ideas': commercialization strategies for technology entrepreneurs. RP 32(2): 333-350.

Gartner WB. 1985. A Conceptual Framework for Describing the Phenomenon of New Venture Creation. Academy of Management Review 10(4): 696-706.

Girotra K, Terwiesch C, Ulrich KT. 2010. Idea Generation and the Quality of the Best Idea. Management Science 56(4): 591-605.

Granovetter MS. 1973. The Strength of Weak Ties. American Journal of Sociology 78(6): $1360-1380$.

Grossman W. 2012, April 17. Book review: Digital Wars. ZDNet. Available at: http://www.zdnet.com/book-review-digital-wars-4010025892/ [29 March 2014].

Groteke DE. 1983, July 19. Apparatus and method for filtration of molten metal. Available at: http://www.google.com/patents/US4394271.

Groteke DE, Kearney AL. 1986, January 14. Molten metal transfer crucible with external filter. Available at: http://www.google.com/patents/US4564175.

Gruber M, MacMillan IC, Thompson JD. 2013. Escaping the Prior Knowledge Corridor: What Shapes the Number and Variety of Market Opportunities Identified Before Market Entry of Technology Start-ups? Organization Science 24(1): 280-300.

Haas MR, Hansen MT. 2007. Different knowledge, different benefits: toward a productivity perspective on knowledge sharing in organizations. Strategic Management Journal 28(11): 1133-1153. 
Hall BH, Jaffe AB, Trajtenberg M. 2001. The NBER Patent Citations Data File: Lessons, Insights and Methodological Tools. NBER Working Paper Series. Available at: http://papers.nber.org/papers/w8498.pdf.

Hamel G. 1999. Bringing Silicon Valley Inside. Harvard Business Review 77(5): 70-84.

Helfat CE. 1994. Evolutionary Trajectories in Petroleum Firm R\&D. Management Science 40(12): 1720-1747.

von Hippel E. 1988. The sources of innovation. Oxford University Press: New York.

Hoetker G, Agarwal R. 2007. Death Hurts, But It Isn't Fatal: The Postexit Diffusion of Knowledge Created by Innovative Companies. Academy of Management Journal 50(2): 446467.

Hsu DH. 2006. Venture Capitalists and Cooperative Start-up Commercialization Strategy. Management Science 52(2): 204-219.

Hsu DH, Ziedonis RH. 2008. Patents as Quality Signals for Entrepreneurial Ventures. Academy of Management Proceedings 2008(1): 1-6.

Hsu DH, Ziedonis RH. 2013. Resources as dual sources of advantage: Implications for valuing entrepreneurial-firm patents. Strategic Management Journal 34(7): 761-781.

Hunt J, Garant J-P, Herman H, Munroe DJ. 2013. Why are women underrepresented amongst patentees? Research Policy 42(4): 831-843.

Jaffe AB, Fogarty MS, Banks BA. 1998. Evidence from Patents and Patent Citations on the Impact of NASA and Other Federal Labs on Commercial Innovation. The Journal of Industrial Economics 46(2): 183-205.

Jensen TL, Leth-Petersen S, Nanda R. 2015. Home Equity Finance and Entrepreneurial Performance - Evidence from a Mortgage Reform. SSRN Scholarly Paper, Social Science Research Network, Rochester, NY. Available at: http://papers.ssrn.com/abstract=2506111.

Jewkes J, Sawers D, Stillerman R. 1971. Sources Of Invention, Enlarged 2nd. W. W. Norton and Company, Inc.: London.

Johnstone III AE, Ratliff FW. 2006, September 19. Swivel joint apparatus and method for utility supply to a rotatable building. Available at:

http://www.google.com/patents/US7107725.

Jones BF. 2009. The Burden of Knowledge and the 'Death of the Renaissance Man': Is Innovation Getting Harder? The Review of Economic Studies 76(1): 283-317.

Jones B, Parker RL, Durham P. 1997, October 21. Firearm casing device. Available at: http://www.google.com/patents/US5678344. 
Jones B, Parker RL, Durham P. 2000, September 19. Firearm casing device. Available at: http://www.google.com/patents/US6119388.

Kacperczyk AJ. 2013. Social Influence and Entrepreneurship: The Effect of University Peers on Entrepreneurial Entry. Organization Science 24(3): 664-683.

Katila R, Shane S. 2005. When Does Lack of Resources Make New Firms Innovative?

Academy of Management Journal 48(5): 814-829.

Kerr SP, Kerr WR, Nanda R. 2015. House Money and Entrepreneurship. SSRN Scholarly Paper, Social Science Research Network, Rochester, NY. Available at: http://papers.ssrn.com/abstract=2638045.

Kirzner I. 1973. Competition and entrepreneurship. University of Chicago Press: Chicago, Ill.

Klepper S. 2007. Disagreements, Spinoffs, and the Evolution of Detroit as the Capital of the U.S. Automobile Industry. Management Science 53(4): 616-631.

Klepper S, Sleeper S. 2005. Entry by Spinoffs. Management Science 51(8): 1291-1306.

Kogut B, Zander U. 1993. Knowledge of the Firm and the Evolutionary Theory of the Multinational Corporation. Journal of International Business Studies 24(4): 625-645.

Konczal J. 2013. The Most Entrepreneurial Metropolitan Area? The Kauffman Foundation, Kansas City, MO: 36. Available at:

http://www.kauffman.org/ /media/kauffman_org/research\%20reports\%20and\%20covers/201 3/11/the\%20most $\% 20$ entrepreneurial\%20metropolitan $\% 20$ area.pdf.

Krueger NF. 2002. Entrepreneurship: Critical Perspectives on Business and Management. Taylor \& Francis: London ;New York.

Kuppuswamy V, Mollick ER. 2015. Hubris and Humility: Gender Differences in Serial Founding Rates. SSRN Scholarly Paper, Social Science Research Network, Rochester, NY. Available at: http://papers.ssrn.com/abstract=2623746.

Lai R, D’Amour A, Yu A, Sun Y, Fleming L. 2013. Disambiguation and Co-authorship Networks of the U.S. Patent Inventor Database (1975 - 2010). The Harvard Dataverse Network [Distributor] V5 [Version]. Available at: http://hdl.handle.net/1902.1/15705.

Lloyd M, Blows J. 2009. Who Holds the Power? Lessons from hybrid car innovation for clean technologies. Griffith Hack Patent Attorneys. Available at:

http://www.griffithhack.com.au/mediacentreLessonsfromHybridCarInnovationforCleanTechnologies.

Low MB, MacMillan IC. 1988. Entrepreneurship: Past Research and Future Challenges. Journal of Management 14(2): 139-161. 
Malerba F, Nelson R, Orsenigo L, Winter S. 2007. Demand, innovation, and the dynamics of market structure: The role of experimental users and diverse preferences. Journal of Evolutionary Economics 17(4): 371-399.

Malerba F, Orsenigo L. 1999. Technological entry, exit and survival: an empirical analysis of patent data. Research Policy 28(6): 643-660.

Marx M, Kacperczyk A. 2015, December. Revisiting the Small-Firm Effect on Entrepreneurship: Evidence from Firm Dissolutions. Working Paper, .

Marx M, Strumsky D, Fleming L. 2009. Mobility, Skills, and the Michigan Non-Compete Experiment. Management Science 55(6): 875-889.

Mollick ER. 2012. Filthy Lucre: What Motivates the Commercialization of Innovations? SSRN Scholarly Paper, Social Science Research Network, Rochester, NY. Available at: http://papers.ssrn.com/abstract=1742380.

Nanda R, Sørensen JB. 2010. Workplace Peers and Entrepreneurship. Management Science 56(7): 1116-1126.

Nerkar A, Paruchuri S. 2005. Evolution of R\&D Capabilities: The Role of Knowledge Networks Within a Firm. Management Science 51(5): 771-785.

Nerkar A, Shane S. 2003. When do start-ups that exploit patented academic knowledge survive? International Journal of Industrial Organization 21(9): 1391-1410.

Nerkar A, Shane S. 2007. Determinants of invention commercialization: an empirical examination of academically sourced inventions. Strategic Management Journal 28(11): $1155-1166$.

Orr S. 1999, June 19. Innovative Sports sets its sights on success. GoUpstate.com. Available at: http://www.goupstate.com/article/19990619/news/906190302 [21 March 2016].

Paice, LLC. 2010, July 16. Paice and Ford Reach Settlement in Hybrid Vehicle Patent Infringement Disputes. Available at: http://www.prnewswire.com/news-releases/paice-andford-reach-settlement-in-hybrid-vehicle-patent-infringement-disputes-98646969.html [18 October 2012].

Prusa TJ, Schmitz Jr. JA. 1991. Are new firms an important source of innovation?: Evidence from the PC software industry. Economics Letters 35(3): 339-342.

Ratliff FW, Johnstone III AE, Berg DA, Rogers ML. 2009, May 26. Rotatable building. Available at: http://www.google.com/patents/US7536831.

Roach M, Sauermann H. 2015. Founder or Joiner? The Role of Preferences and Context in Shaping Different Entrepreneurial Interests. Management Science 61(9): 2160-2184. 
Scherer FM, Ross D. 1990. Industrial Market Structure and Economic Performance, 3rd ed. Houghton Mifflin Company.

Schmookler J. 1957. Inventors Past and Present. The Review of Economics and Statistics 39(3): 321-333.

Schumpeter JA. 1934. The Theory of Economic Development. Harvard University Press: Cambridge, MA.

Schumpeter JA. 1942. Capitalism, Socialism, and Democracy. Harper \& Row: New York.

Severinsky AJ. 1989, March 28. AC to DC power converter with integrated line current control for improving power factor. Available at:

http://www.google.com/patents/US4816982.

Severinsky AJ. 1994, September 6. Hybrid electric vehicle. Available at:

http://www.google.com/patents/US5343970?dq=severinsky\&hl=en\&sa=X\&ei=rH2BULXdJ ojk9ATZ4oFw\&ved=0CDcQ6AEwAg.

Severinsky AJ. 2001, April 3. Hybrid vehicle. Available at: http://www.google.com/patents/US6209672.

Severinsky AJ, Louckes T. 2011, October 26. Engine start and shutdown control in hybrid vehicles. Available at: http://www.google.com/patents/EP1932704B1?cl=en.

Shah SK. 2005. Open beyond software. In Open Sources 2, The Continuing Evolution, Dibona C, Cooper D, Stone M (eds). O’Reilly Media: Sebastopol, CA: 339-360.

Shah SK, Smith SW, Reedy EJ. 2012, February. Who Are User Entrepreneurs? Findings on Innovation, Founder Characteristics \& Firm Characteristics. Kauffman Foundation Report, Kansas City, MO.

Shah SK, Tripsas M. 2007. The accidental entrepreneur: the emergent and collective process of user entrepreneurship. Strategic Entrepreneurship Journal 1(1-2): 123-140.

Shane S. 2000. Prior Knowledge and the Discovery of Entrepreneurial Opportunities. Organization Science 11(4): 448-469.

Shane S. 2001a. Technological Opportunities and New Firm Creation. Management Science 47(2): 205-220.

Shane S. 2001b. Technology Regimes and New Firm Formation. Management Science 47(9): 1173-1190.

Shane S, Venkataraman S. 2000. The Promise of Entrepreneurship as a Field of Research. The Academy of Management Review 25(1): 217-226. 
Singh J, Fleming L. 2010. Lone Inventors as Sources of Breakthroughs: Myth or Reality? Management Science 56(1): 41-56.

Sirilli G. 1987. Patents and inventors: An empirical study. Research Policy 16(2-4): 157174.

Social Security Administration. 2014. Social Security Administration Name and Gender Data. Available at: https://www.ssa.gov/oact/babynames/limits.html [3 November 2015].

Somaya D. 2012. Patent Strategy and Management An Integrative Review and Research Agenda. Journal of Management 38(4): 1084-1114.

Spender J-C, Grant RM. 1996. Knowledge and the Firm: Overview. Strategic Management Journal 17(Special Issue: Knowledge and the Firm): 5-9.

Stearns LB, Allan KD. 1996. Economic Behavior in Institutional Environments: The Corporate Merger Wave of the 1980s. American Sociological Review 61(4): 699-718.

Stuart TE, Ding WW. 2006. When Do Scientists Become Entrepreneurs? The Social Structural Antecedents of Commercial Activity in the Academic Life Sciences. American Journal of Sociology 112(1): 97-144.

Stuart TE, Hoang H, Hybels RC. 1999. Interorganizational Endorsements and the Performance of Entrepreneurial Ventures. Administrative Science Quarterly 44(2): 315-349.

Teece DJ. 1986. Profiting from technological innovation: Implications for integration, collaboration, licensing and public policy. Research Policy 15(6): 285-305.

Thornton PH. 1995. Accounting for acquisition waves: evidence from the U.S. college publishing industry. In The Institutional Construction of Organizations: Inernational and Longitudinal Studies, Scott WR, Christensen S (eds). Sage: Thousand Oaks, Calif.: 199-225.

Thornton PH. 1999. The Sociology of Entrepreneurship. Annual Review of Sociology 25: 1946.

Tong X, Frame JD. 1994. Measuring national technological performance with patent claims data. Research Policy 23(2): 133-141.

Tripsas M. 2008. Customer preference discontinuities: a trigger for radical technological change. Managerial and Decision Economics 29(2-3): 79-97.

Turner SF, Mitchell W, Bettis RA. 2010. Responding to Rivals and Complements: How Market Concentration Shapes Generational Product Innovation Strategy. Organization Science 21(4): 854-872.

US Census Bureau Center for Economic Studies. 2015, September. US Census Bureau Center for Economic Studies Business Dynamics Statistics, establishment characteristic data 
table page. Available at: http://www.census.gov/ces/dataproducts/bds/data_estab.html [30 September 2015].

Vieri R. 2009, October 29. Systems and methods of contextual advertising. Available at: www.google.com/patents/WO2009093155A3.

Vieri R. 2013, April 16. Systems and methods of contextual advertising. Available at: https://www.google.com/patents/US8423412?dq=US8423412.

Vieri R, Tomasso C, Vieri F. 2007, December 18. System for sending text messages converted into speech through an internet connection to a telephone and method for running it. Available at: http://www.google.com/patents/US7310329.

Wadhwa V, Freeman RB, Rissing BA. 2008. Education and Tech Entrepreneurship. SSRN Electronic Journal. Available at:

http://papers.ssrn.com/sol3/papers.cfm?abstract_id $=1127248$.

Wadhwa V, Holly K, Aggarwal R, Salkever A. 2009. Anatomy of an Entrepreneur: Family Background and Motivation. SSRN Scholarly Paper, Social Science Research Network, Rochester, NY. Available at: http://papers.ssrn.com/abstract=1431263.

Weick CW, Eakin CF. 2005. Independent inventors and innovation: An empirical study. The International Journal of Entrepreneurship and Innovation 6(1): 5-15.

Zillow.com. 2015. Zillow Home Value Data. Zillow Research. Available at: http://www.zillow.com/research/data/ [3 November 2015]. 